\title{
Does Consumer Protection Enhance Disclosure Credibility in Reward Crowdfunding?
}

\author{
Stefano Cascino \\ London School of Economics \\ s.cascino@1se.ac.uk \\ Maria Correia \\ London School of Economics \\ m.m.correia@1se.ac.uk \\ Ane Tamayo \\ London School of Economics \\ a.m.tamayo@1se.ac.uk
}

Forthcoming at Journal of Accounting Research

October 2019

\begin{abstract}
We study how the interplay of disclosure and regulation shapes capital allocation in reward crowdfunding. Using data from Kickstarter, the largest online reward crowdfunding platform, we show that, even in the absence of clear regulation and enforcement mechanisms, disclosure helps entrepreneurs access capital for their projects and bolsters engagement with potential project backers, consistent with the notion that disclosure mitigates moral hazard. We further document that, subsequent to a change in Kickstarter's terms of use that increases the threat of consumer litigation, the association between project funding and disclosure becomes stronger. This evidence suggests that consumer protection regulation enhances the perceived credibility of disclosure. We find the effect of the change in terms of use to be more pronounced in states with stricter consumer protection regulations. Taken together, our findings yield important insights on the role of disclosure, as well as on the potential effects of increased regulation on crowdfunding platforms.
\end{abstract}

Keywords: Crowdfunding, Disclosure, Consumer Protection, Regulation, Enforcement

JEL Classification: G18, M41, M48, O31, O38

Accepted by Philip Berger. We appreciate the helpful comments and suggestions of an anonymous referee, Saverio Bozzolan, Ulf Brüggemann, Sudheer Chava, Mark Clatworthy, Miklos Farkas, Joachim Gassen, Stanimir Markov, Facundo Mercado, Maximilian Muhn, Raghu Rau, Mariano Scapin, Henri Servaes, Felix Vetter, and seminar participants at the $12^{\text {th }}$ Tel Aviv Conference in Accounting, 2018 Cambridge Centre for Alternative Finance Conference, Aarhus University, ESSEC Business School, King's College London, Humboldt University of Berlin, INSEAD, London School of Economics, University of Bologna, University of Bolzano, University of Bristol, University of Exeter, and Warwick Business School. We thank Daniel Rabetti for providing web-scraping research assistance. An Online Appendix to this paper can be downloaded at http://research.chicagobooth.edu/arc/journal-of-accounting-research/online-supplements. 


\title{
Does Consumer Protection Enhance Disclosure Credibility in Reward Crowdfunding?
}

\begin{abstract}
We study how the interplay of disclosure and regulation shapes capital allocation in reward crowdfunding. Using data from Kickstarter, the largest online reward crowdfunding platform, we show that, even in the absence of clear regulation and enforcement mechanisms, disclosure helps entrepreneurs access capital for their projects and bolsters engagement with potential project backers, consistent with the notion that disclosure mitigates moral hazard. We further document that, subsequent to a change in Kickstarter's terms of use that increases the threat of consumer litigation, the association between project funding and disclosure becomes stronger. This evidence suggests that consumer protection regulation enhances the perceived credibility of disclosure. We find the effect of the change in terms of use to be more pronounced in states with stricter consumer protection regulations. Taken together, our findings yield important insights on the role of disclosure, as well as on the potential effects of increased regulation on crowdfunding platforms.
\end{abstract}

Keywords: Crowdfunding, Disclosure, Consumer Protection, Regulation, Enforcement

JEL Classification: G18, M41, M48, O31, O38 


\section{Introduction}

We study how the interplay of disclosure and regulation shapes capital allocation in reward crowdfunding. Crowdfunding, essentially a type of microfinance, has experienced an unprecedented growth over the last few years, becoming an important driver of economic and financial development. The World Bank has estimated that crowdfunding could reach U.S. $\$ 90$ billion by 2020 , surpassing venture capital and angel capital as a means of financing. ${ }^{1}$ While much of this growth has been spurred by lending-based crowdfunding, an interesting phenomenon has been the strong emergence of reward crowdfunding, in which project creators (i.e., entrepreneurs) promise future in-kind rewards in exchange for backer contributions. On reward crowdfunding platforms, project backers represent "hybrid" stakeholders, in between investors and consumers (Belleflame et al., 2015).

The hybrid nature of project backers renders their contractual claims difficult to regulate and enforce in case of contract breach by creators. Reward crowdfunding does not involve the offering of securities and therefore does not fall under the U.S. securities laws or the jurisdiction of the Securities and Exchange Commission (SEC). As such, SEC rules specifically designed for equity crowdfunding do not apply. ${ }^{2}$ Reward crowdfunding platforms also disclaim any liability, stating that they act as mere intermediaries. As it is often the case for evolving technologies, the emergence of reward crowdfunding led to a regulatory limbo, in which backers were initially left without much recourse.

A regulatory void is particularly troublesome given the adverse selection and moral hazard problems that characterize these markets. Information asymmetries between creators and backers regarding creator ability and project quality (adverse selection), coupled with the inability of backers to induce creator effort and ensure that pledged funds are not diverted for

\footnotetext{
1 Forbes, Trends Show Crowdfunding to Surpass VC in 2016, June 9, 2015 (Available at: https://www.forbes.com/sites/chancebarnett/2015/06/09/trends-show-crowdfunding-to-surpass-vc-in-2016/).

2 The Jumpstart Our Business Startups (JOBS) Act, signed into law on April 5, 2012, legalizes equity crowdfunding by relaxing several restrictions related to the sale of securities.
} 
personal consumption (moral hazard), are in fact inherent to crowdfunding (Agrawal et al., 2014; Belleflamme et al., 2015). Project creators may rely on disclosure to signal their ability and project quality (e.g., Grossman, 1981). However, the lack of clear regulation and oversight in the early years of reward crowdfunding, the absence of a trustworthy and independent third-party (e.g., an auditor) that certifies the information disclosed by creators, and the one-time nature of most of these transactions (many creators access these markets only once) may render disclosure not credible. In these markets, in fact, creators can easily engage in cheap talk. ${ }^{3}$ For example, when they provide voluntary disclosures about the project and themselves with the aim of enticing backers into pledging funds, they can oversell the project or, in extreme circumstances, communicate false information in bad faith. ${ }^{4}$

In this paper, we examine two main questions. First, does (voluntary) disclosure facilitate contracting in reward crowdfunding, or is it mainly perceived as cheap talk? Second, to what extent does an increase in regulatory oversight enhance the perceived credibility of disclosure?

We shed light on the above questions by exploiting a widely publicized rule change on Kickstarter, the world leading reward crowdfunding platform. On September 19, 2014, Kickstarter announced that it would change its terms of use to clarify the nature of the contract between backers and creators. ${ }^{5}$ This change, which was aimed at alleviating moral hazard, essentially strengthened the contractual position of backers by explicitly requiring creators to fulfill their obligation to deliver the promised rewards (or refund pledges) and by clearly spelling out the possibility of legal action against creators. The main mechanism

\footnotetext{
${ }^{3}$ Stocken (2000) develops a model in which managers can make unverifiable disclosures to investors about the payoffs of a project and shows that, in a single-period game, managers do not make any informative disclosures in equilibrium.

${ }^{4}$ Project disclosures may, instead, be truthful. Gigler (1994) develops a model in which proprietary costs, and firms' opposing incentives to disclose positive (negative) information to investors (competitors) may render disclosures credible. Agrawal et al. (2014) highlight other mechanisms that can lead to truthful disclosure in the context of crowdfunding, and specifically the role of crowd due diligence. There are, in fact, typically many more (and more varied) individuals reviewing a given project than in a traditional financing setting.

${ }^{5}$ As Kickstarter typically calls its terms of use "rules," we refer to the change in Kickstarter's terms of use announced on September 19, 2014 as "the rule change."
} 
through which such legal action may take place is consumer protection regulation, which is aimed at protecting consumers from "unfair and deceptive trade practices" and significantly varies in stringency across U.S. states. While consumer protection regulation was already in place to protect "traditional" consumers, the September 2014 rule change brought the possibility of legal action to the attention of creators and backers, thereby shifting substantial contractual risk from backers to creators. This effectively altered the perception of consumer protection law applicability in the context of Kickstarter given that in 2012 (i.e., prior to the rule change) Kickstarter had emphasized that they are not a "store" precisely to limit their own legal exposure. ${ }^{6}$

In our empirical analysis, we first examine the association between disclosure and project funding to provide initial evidence on the extent of disclosure credibility on the platform. We find that disclosure (measured as either the length of a project's campaign pitch or the length of a project's risks and challenges section) exhibits a positive and robust association with the amount pledged and the probability of a project being funded, which suggests that backers take creator disclosures into account when deciding to make a pledge.

Next, we turn to the change in Kickstarter's terms of use announced on September 19, 2014. The cross-sectional variation in consumer protection stringency across states allows us to use a research design in the spirit of a generalized difference-in-differences (DiD) to gauge the differential effect of this change on the perceived credibility of disclosure. Our identification strategy effectively compares disclosure credibility (i.e., the association between project success and disclosure) before and after the rule change by looking at differential responses across states, depending on the varying degrees of stringency in their pre-existing consumer protection laws. Our identifying assumption is that, in the absence of the rule change, states with different levels of consumer protection would exhibit similar

\footnotetext{
6 Kickstarter, Kickstarter is not a store, September 19, 2012 (Available at: https://www.kickstarter.com/blog/kickstarter-is-not-a-store).
} 
trends in disclosure credibility (i.e., parallel trends). We assess the validity of this assumption by testing for differences in pre-treatment trends and find that, before the rule change, the association between disclosure and both the likelihood that a project is funded and the amount of funds pledged to a project exhibits similar trends across states with varying degrees of consumer protection stringency. After the rule change, disclosure credibility experiences a sharp and persistent increase in states with stricter consumer protection regulation. We conduct a battery of sensitivity tests to rule out alternative explanations, including a county-level analysis in which we restrict our sample to contiguous counties in different states, a test that relies on shorter windows surrounding the event date, and an analysis employing different fixed effects structures to absorb the potentially confounding effect of state-level time-varying unobservable factors.

Moreover, we examine alternative measures of project success, such as the number of (new and returning) backers and the level of backer engagement. The evidence from these tests is also consistent with disclosure playing a stronger role in facilitating contracting between backers and creators in states with stricter consumer protection following the rule change.

Further, we conduct cross-sectional tests to explore heterogeneity in treatment effects and find that the increase in the perceived credibility of disclosure varies with litigation risk. Specifically, the effect of the rule change on the project success-disclosure relation is stronger when litigation risk is likely to be higher, namely when project rewards are larger, when confidence in courts is higher, and, to some extent, when courts have a lower caseload.

Our evidence also suggests that the increase in disclosure credibility is not explained by backers increasingly falling for cheap talk after the rule change but, rather, by an improvement in the attributes of disclosure and in the association between disclosure and project quality. After the rule change, creator disclosures become longer, more informative, 
easier to read, and rely more on legal terms and quantitative information in states with stricter consumer protection regulation.

Finally, we show that creators face direct and indirect costs of disclosure. Consistent with the argument that disclosure may reveal proprietary information, we find that, following the rule change, creators of more innovative projects increase their disclosures to a lesser extent than creators of less innovative projects. Furthermore, in line with the idea that disclosure may increase the cost of communicating with backers, we show that, after the rule change, disclosure is associated with greater creator involvement, as well as with more and longer replies to backers.

Our study contributes to the literature in several ways. First, we contribute to prior research on the role of disclosure in capital markets. We answer the recent call in Leuz and Wysocki (2016) and Leuz (2018) for more evidence on the role of disclosure in alternative, and often unregulated, financing venues. We show that, even in the absence of clear regulation and enforcement mechanisms, disclosure can mitigate moral hazard and adverse selection problems, thereby facilitating contracting between creators and backers. Second, by showing that consumer protection regulation affects the perceived credibility of disclosure, we contribute to the law and economics literature that examines the role of regulation and enforcement in addressing moral hazard and adverse selection (e.g., Mahoney, 2009). We are among the first to empirically examine the effect of consumer protection regulation on disclosure credibility. Third, we contribute to the nascent literature on the role of disclosure in peer-to-peer lending (Michels, 2012), reward crowdfunding (e.g., Mollick, 2014, 2015, 2016; Courtney et al., 2017), and crypto-tokens markets (e.g., Bourveau et al., 2019), by highlighting how disclosure and regulation facilitate contracting in a market plagued by information asymmetries. 


\section{Institutional Background}

\subsection{Reward Crowdfunding}

Reward crowdfunding is a form of financing whereby (a large number of small) backers provide funds to creators in exchange for rewards (often in the form of products that creators intend to develop). Reward crowdfunding transactions often consist of "pre-sales," in which backers play a "double role" as consumers and investors (Belleflamme et al. (2015) label these hybrid stakeholders "prosumers"). As such, reward crowdfunding allows an entrepreneur to contract with future consumers and obtain valuable information about the demand for a product before the investment is sunk (Chemla and Tinn, 2018; Strausz, 2017). In addition to reducing demand uncertainty, reward crowdfunding serves the purpose of providing creators with inputs on their products and ideas for modifications and extensions, which ultimately promote user-driven innovation (Agrawal et al., 2014; Belleflamme et al., 2015). Finally, reward crowdfunding plays a role in talent discovery by allowing creators to signal their ability (Gutiérrez and Sáez, 2018).

The aforementioned advantages come at a cost, however. First, while other sources of funding may allow entrepreneurs to keep their business ideas secret from competitors, in reward crowdfunding they must pitch their products on a public platform. This may have repercussions on patentability (i.e., their ideas may be copied) and limit their bargaining power with potential suppliers (Agrawal et al., 2014). Moreover, because individual pledges are typically small, and projects involve a large number of backers, managing communication with backers may be costly, especially when the delivery of rewards is delayed. When reward crowdfunding is used as an alternative to other sources of financing, such as angel capital and venture capital, the entrepreneur may miss out on the value created by these players' industry knowledge and relationships. For that reason, different sources of financing are often used in 
combination, with venture capitalists sometimes requiring entrepreneurs to launch a campaign on a reward crowdfunding platform to reduce demand uncertainty before investing.

Backers pledge funds to reward crowdfunding campaigns for several reasons (Gerber et al., 2012). These include philanthropy, engaging and contributing to a trusting and creative community, and supporting others and their causes, but also, importantly, the project rewards themselves, often in the form of early access to new products.

Reward crowdfunding platforms typically receive a transaction fee for successful projects (in the case of Kickstarter this transaction fee is $5 \%$ of the total funding amount). Therefore, their objective is to maximize the number of successful projects and the amount pledged to these projects. This implies creating a large community of users, attracting highquality projects, and facilitating the matching between creators and backers (Agrawal et al., 2014).

An emerging literature in entrepreneurship has started to examine the determinants of successful project funding (e.g., Mollick, 2014; Barbi and Bigelli, 2017; Courtney et al., 2017; Lin and Pursiainen, 2018). Collectively, these studies highlight the importance of several factors, such as the social capital of creators (e.g., number of friends on Facebook, support for other projects on Kickstarter), the duration of the funding period, the number of rewards, and whether a given project is featured on Kickstarter as "project of the day.",

However, evidence on whether creator disclosures help backers assess project quality on reward crowdfunding platforms is surprisingly scant. The role of disclosure in these markets is particularly interesting because information asymmetries between creators and backers are pervasive and often create adverse selection and moral hazard issues. Project quality and creator ability are typically not observable by backers. Backers are also unable to induce creator effort and, in extreme cases, there is a risk that creators may use funds for their

\footnotetext{
${ }^{7}$ This literature further documents that a large number of successfully-funded projects have developed into business ventures generating additional investments and revenues outside Kickstarter and increasing employment (Mollick, 2016), which highlights the economic significance of this platform.
} 
personal consumption, which would constitute outright fraud. Adverse selection plays a secondary role in the sense that misrepresenting project information is, in general, only profitable for a creator in the presence of moral hazard (Strausz, 2017).

Prior studies have examined investor reactions to voluntary disclosures in other unregulated markets and found that investors respond to these disclosures. Sivakumar and Waymire (1994) study voluntary disclosures made by NYSE firms from 1905 to 1910, when there were minimal reporting requirements and no accounting standards. Michels (2012) examines voluntary disclosures made by borrowers on the Prosper.com peer-to-peer lending platform. More recently, Bourveau et al. (2019) investigate the role of disclosure and information intermediaries in crypto-tokens markets. While one may argue that reward crowdfunding shares features that are similar to those of unregulated equity markets, peer-topeer lending platforms, and crypto-tokens markets, the one-shot nature of the contractual relationship between creators and backers (i.e., single-period game), as well as the different nature of payoffs, the absence of a secondary market, and the hybrid nature of project backers (in between consumers and investors), may limit the extent to which other studies' findings generalize to reward crowdfunding. Therefore, whether creator disclosures facilitate contracting between backers and creators is an open empirical question.

\subsection{Consumer Protection Regulation and Reward Crowdfunding}

The main objective of regulation in securities markets is to guarantee market integrity and to ensure investor protection (e.g., Goshen and Parchomovsky 2006; Mahoney 2009; Christensen et al., 2017). Market regulators often impose stringent disclosure requirements on security issuers to meet this objective. Costly disclosure requirements, however, may impose an excessive burden on small firms, which are usually the most innovative and high-growth ventures. Therefore, market regulators are confronted with a choice between: (i) a lightlyregulated market, capable of attracting small and innovative firms that can enjoy low 
disclosure burdens; and (ii) a heavily-regulated market, in which small high-growth firms may be discouraged by disproportionate compliance requirements (Brüggemann et al., 2017).

The above reasoning is particularly pertinent to the case of reward crowdfunding platforms. On the one hand, the competitive advantage of these alternative markets is to provide a venue for venture financing with very limited (if any) regulations, which should allow creators to focus on innovative (high-risk) projects with a view to ultimately spur innovation. On the other hand, the regulatory uncertainty and minimal standards for disclosure verifiability typically plague these platforms with moral hazard problems because of information asymmetries which may ultimately lead to market failure (e.g., Akerlof, 1970; Grossman, 1981; Milgrom, 1981).

Reward crowdfunding platforms, such as Kickstarter, are not subject to any bespoke regulation. Furthermore, as reward crowdfunding does not involve securities, it does not fall under the U.S. securities laws or the jurisdiction of the SEC. As in the case of other evolving technologies, which often lead to a game of catch-up by regulators and enforcement agencies, the development of reward crowdfunding has initially led to a regulatory limbo.

The change in Kickstarter's terms of use in September 2014, however, clarified the nature of the contract between backers and creators and set out the terms that govern that contract. ${ }^{8}$ The new terms of use now specifically state that: "When a project is successfully funded, the creator must complete the project and fulfill each reward" and, if unable to do so, must remedy the situation by demonstrating that "they have used funds appropriately and made every reasonable effort to complete the project as promised" and that they "have made

\footnotetext{
${ }^{8}$ When Kickstarter announced the change in terms of use on its blog, it indicated that the goal of the change was "to make sure every part of the Kickstarter system is clear and straightforward." The change may have also been prompted by other potential factors such as: (i) the negative coverage received by a set of highlypublicized projects that eventually failed; and (ii) Kickstarter's desire to clarify that the platform bears no legal responsibility for funded projects that do not deliver the promised rewards. We discuss these and other potential factors in Section 2 of the Online Appendix.
} 
no material misrepresentations in their communication to backers." ${ }^{\text {"9 }}$ Kickstarter clearly spells out the possibility of legal recourse, and the associated legal liability for creators: "The creator is solely responsible for fulfilling the promises made in their project. If they're unable to satisfy the terms of this agreement [i.e., deliver rewards or return backer contributions], they may be subject to legal action." Prior to this change, the terms of use did not mention the possibility of legal action by backers at all. ${ }^{10}$ The change in terms of use was highly publicized by Kickstarter, drew the attention of both the mainstream and tech-dedicated media, and was widely discussed on social media. These discussions emphasized the heightened litigation risk and were later followed by a number of landmark lawsuits (see Appendix A). ${ }^{11}$

The main mechanism through which legal action may take place is consumer protection regulation aimed at protecting consumers from "unfair and deceptive trade practices." The introduction of Kickstarter's new terms of use is important because it made users aware that consumer protection laws could apply to reward crowdfunding. Prior to the rule change, Kickstarter had instead emphasized that backers (creators) were not consumers (merchants) purchasing (selling) goods. We discuss the applicability of consumer protection laws to reward crowdfunding in more detail in Appendix A.

Consumer protection regulation is enforced at the federal level by the Federal Trade Commission (FTC). In addition, U.S. states have their own consumer fraud statutes, the Unfair and Deceptive Acts and Practices (UDAP) statutes, which vary significantly in

\footnotetext{
${ }^{9}$ See https://www.kickstarter.com/terms-of-use.

${ }^{10}$ See https://www.kickstarter.com/terms-of-use/oct2012?country=US.

11 For example, on September 19, 2014 TechCrunch published an article highlighting Kickstarter's revised terms of use in which it stated: "Kickstarter also reminds creators that they need to be "honest" and not make "material misrepresentations in their communication to backers." (In other words, scammers beware.) Additionally, the terms now state that creators who are unable to stand by the promises they made in their project may be subject to legal action by backers." Similarly, on September 22, 2014 NBC News reported: "Kickstarter is trying to codify the current swampy situation around projects canceled after creators have the cash in hand. (...) If creators don't make good on the promises made in their campaigns, they must explain what happened, return any unused funds, and could face potential legal action from backers." See Section 1 of the Online Appendix for further details on the media coverage of the change in Kickstarter's terms of use.
} 
strength and are enforced by state agencies (usually the State Attorney General). Public enforcement agencies (at the federal and state level) have limited resources and, therefore, cannot pursue all cases. Private litigation is another avenue of legal recourse available to backers in some states. In this respect, class actions may play an important role as projects often involve many backers, each pledging a small amount. ${ }^{12}$

The strength of consumer protection laws (UDAP statues) varies extensively from state to state along several dimensions, namely, their substantive prohibitions, their scope, the remedies they provide for the state enforcement agency, and the remedies they provide for consumers (see Appendix A). The National Consumer Law Center's report on UDAP provides information on state consumer protection laws along these four broad dimensions. Based on this information, we construct an index that captures the strength of state-level consumer protection regulation (see Appendix A, Table A-2). Figure 1 illustrates the differential strengths of consumer protection regulation across U.S. states.

\section{Data and Descriptive Statistics}

To examine the interplay of disclosure and regulation in reward crowdfunding, we scrape information from Kickstarter using R scripts. ${ }^{13}$ Table 1, Panel A, provides the details of our sample selection procedure. We identify 332,364 projects launched between April 28, 2009 (i.e., the date of Kickstarter's official launch) and July 15, 2017. These projects represent $92 \%$ of the 361,804 projects that were launched during that period according to Kickstarter. ${ }^{14}$ To the best of our knowledge, our sample of Kickstarter projects is more

\footnotetext{
12 For example, the backers of Onagofly filed in 2017 a class action lawsuit against its creator for breach of contract, alleging "uniform and consistent misrepresentations to all its customers" (Alan Black et al. vs. Shenzen Sunshine Technology Development Ltd).

${ }^{13}$ Figure OA-1 in the Online Appendix provides an example of a Kickstarter project webpage.

$14 \mathrm{We}$ obtain the total number of projects launched during that period from https://www.kickstarter.com/help/stats using the Wayback Machine (available at: http://archive.org/web/) to revert to the saved snapshot of the website that is closer to July 15, 2017 (i.e., July 13, 2017). The reason why our coverage is not $100 \%$ is that there is a limit to the number of projects shown by Kickstarter in each search. This requires us to repeat our searches by running scripts that automatically change the seed. To ensure that our
} 
comprehensive in coverage than those of prior studies (cf. $86 \%$ coverage in Lin and Pursiainen (2018)). We obtain information on the project funding period from the campaign and updates tabs, and the project location from the campaign tab. We delete projects for which we are unable to determine funding period and location country (417 and 1,722 projects, respectively). We drop 75,131 foreign projects thus restricting our sample to U.S. projects only. We further limit our sample to projects with funding goals greater than zero for which we are able to identify the project state. Project location must be consistent with the address, bank account, government-issued ID, and major debit or credit card details provided by creators. Our final sample consists of 255,017 projects, $80 \%$ of which launched in years 2012 to 2016 (Table 1, Panel B).

$57 \%$ of the projects are in the "Film and Video," "Music," "Publishing," and "Games" categories (Table 1, Panel C). "Art" and "Technology" are also sizeable categories, each representing approximately $7 \%$ of our sample. Projects often involve modest amounts: $43 \%$ of the sample projects have funding goals below U.S. $\$ 5,000$, and only $27 \%$ have funding goals above U.S. $\$ 15,000$ (Table 1, Panel D). Nonetheless, several projects have raised more than U.S. \$10 million. These include the Pebble E-Paper watch, Pebble Time and Pebble Time 2 in 2012, 2015, and 2016, respectively, the Coolest Cooler in 2014, and the Kingdom Death: Monster 1.5 tabletop game in 2017.

Table 1, Panel E, presents descriptive statistics for the projects in our sample. ${ }^{15}$ The average (median) funding goal is U.S. $\$ 18,124$ (U.S. $\$ 5,000$ ). The amount pledged is on average lower (U.S. \$6,597) reflecting the fact that only $39 \%$ of the projects are successful. Figures OA-2, OA-3, and OA-4 in the Online Appendix graphically illustrate the extent of variation in total number of projects, average number of successful projects, and total amount

sample is the most comprehensive, we combine the links retrieved from this search with a set of links made publicly available by Web Robots at http://webrobots.io/kickstarter-datasets/.

${ }^{15}$ All continuous variables are winsorized at the $1^{\text {st }}$ and $99^{\text {th }}$ percentile of their distributions. All variables are defined in Appendix B. 
pledged across U.S. states. While the number of projects and the total amount pledged are, to a large extent, geographically concentrated (e.g., in California and New York), the number of successful projects appears to be more evenly distributed across states. The average (median) number of backers is 79 (15). The majority of backers have previously supported other projects on Kickstarter (a project attracts on average 50 returning backers). Backers often interact with project creators and other backers via the comments tab. They ask questions about the product and make suggestions for product development. Engagement in this forum may be regarded as a sign of project success, especially from backers who regularly support a large number of projects (i.e., superbackers). ${ }^{16}$ The average number of words written by backers (superbackers) in the comments tab is 107 (22).

Project creators must prepare a campaign pitch, in which they describe and promote the project, often providing details of the project's history and milestones achieved thus far, as well as the timeline for completion. In addition, projects include a risks and challenges section. ${ }^{17}$ The average lengths of the campaign pitch and risk and challenges section are 585 and 127 words, respectively. Creators also typically provide their biography (103 words on average), including a link to their Facebook page. Creators have 543 friends on Facebook on average, sometimes work in teams ( $4 \%$ of the projects in our sample), and often back other projects on Kickstarter (on average 6 projects). Finally, project creators must define the funding period (funding periods can last from 1 to 60 days and are on average approximately one month), as well as the range (and pricing) of rewards on offer (on average projects have 8 different reward tiers).

\footnotetext{
${ }^{16}$ Superbackers are backers that have supported more than 25 projects with pledges of at least U.S. $\$ 10$ in the previous year.

${ }^{17}$ Since this section was introduced in 2012, we are able to collect information on risks and challenges for 188,915 projects only.
} 


\section{Empirical Analysis}

\subsection{Identification Strategy}

To examine how the interplay of disclosure and regulation affects the likelihood of project success, we take advantage of the change in Kickstarter's terms of use announced on September $19,2014 .^{18}$ The rule change essentially strengthened the contractual position of backers by explicitly requiring creators to fulfill their obligation to deliver the promised rewards and spelling out the possibility of legal action.

We expect that, following the rule change, the perceived credibility of project disclosure (i.e., the sensitivity of project success to disclosure) increases in the stringency of state consumer protection regulations. To gauge the effect of the change in terms of use on disclosure credibility, we employ a research design in the spirit of a generalized DiD, which allows us to exploit cross-state variation in consumer protection regulation. Our identification strategy effectively compares disclosure credibility before and after the rule change by looking at differential responses across states, depending on the varying degrees of stringency in their pre-existing consumer protection laws. ${ }^{19}$ A maintained assumption underlying our design is that, prior to the rule change, there was limited awareness that state consumer protection laws would apply to Kickstarter creators and backers, despite state consumer protection laws being already in place (an assumption that is supported by a number of

\footnotetext{
${ }^{18}$ While the updated terms of use went into effect on October 19, 2014 (see https://www.kickstarter.com/termsof-use), we conduct our analysis using the announcement date (i.e., September 19, 2014) as the change in terms of use had been already covered in depth by both mainstream and specialized media outlets on that date (Lin and Pursiainen, 2018). Nevertheless, in sensitivity tests (untabulated) we perform our main analyses using the entryinto-force date and find that the results are similar to those reported and none of our inferences change.

${ }^{19}$ To draw a parallel with medical research, our DiD design differs from a randomized controlled trial with dichotomous treatment that compares a single treated group that receives the drug with a single control group that receives the placebo, and is instead more similar to a randomized controlled trial in which the comparison occurs across treated patients receiving differential doses of the drug.
} 
studies in law (e.g., Ganatra (2016))), and that the rule change increased the awareness of creators and backers regarding the possibility of legal action. ${ }^{20}$

To provide support for this assumption, we take a four-pronged approach, which we describe in more detail in Section 1 of the Online Appendix. First, we explore how Kickstarter publicized the introduction of its new terms of use and find that the rule change was announced on Kickstarter's website, social media, and via email to all registered users. Second, we conduct an in-depth analysis of the (mainstream and tech-dedicated) media coverage of the rule change and provide supporting evidence for extensive discussions on how the new terms of use would alleviate moral hazard problems by introducing the possibility of legal actions by backers. Third, we investigate how Kickstarter's rule change was discussed in social media by analyzing a sample of "tweets" surrounding the announcement. The general tenor of these tweets provides interesting anecdotal confirmation that potential backers and creators indeed changed their perceptions of legal liability. Fourth, we supplement this anecdotal evidence with additional empirical tests. We put forward a request to the FTC under the Freedom of Information Act (FOIA) for a list of all consumer complaints involving the Kickstarter platform. We find that the number of consumer complaints increases following the change in Kickstarter's terms of use, especially in states with stronger consumer protection, consistent with the role of consumer protection becoming more salient to backers in those states. Moreover, we conduct a textual analysis of backer comments and find that, after the change in terms of use, backer sentiment increases and delayed reward deliveries as well as fraudulent projects decrease, consistent with heightened perceptions of legal liability by creators.

Taken together, both the anecdotal evidence provided and the results of the empirical tests that we conduct offer strong support for our maintained assumption that (potential)

\footnotetext{
${ }^{20}$ Ganatra (2016) argues that, because prior to the change in terms of use Kickstarter stated that backers were not consumers and creators were not merchants, it was unclear whether consumer protection laws would apply to the platform.
} 
backers and creators were indeed aware of the change in terms of use and that this change was followed by increased awareness of legal liability (by creators) and legal protection (by backers). ${ }^{21}$

To examine the effect of the change in terms of use on disclosure credibility, we estimate various model specifications of the following form:

$y=\varphi\left(\beta_{0}+\beta_{1}(\right.$ Disclosure $)+\beta_{2}($ Post $\times$ Treated $)+\beta_{3}($ Disclosure $\times$ Post $)+\beta_{4}($ Disclosure $\times$

Treated $)+\beta_{5}($ Disclosure $\times$ Post $\times$ Treated $)+\partial^{\prime}$ Controls $+\gamma^{\prime}$ Fixed effects $\left.+\varepsilon\right)$.

The dependent variable $(y)$ is either an indicator capturing whether the amount pledged by backers reaches the project's funding goal (Funded), or the natural logarithm of the amount pledged to a project $(\operatorname{Ln}($ Pledged $)) . \varphi(\cdot)$ indicates the model functional form (i.e., Logit or OLS). Disclosure denotes one of the different project disclosure proxies (i.e., the length of the campaign pitch (Ln(Campaign Pitch) ) and the length of the risks and challenges section (Ln(Risks and Challenges)) measured in number of words). Treated captures the strength of consumer protection laws in the respective state. Post is an indicator variable taking the value of one after September 19, 2014. Controls is a vector of project, creator, and macrolevel control variables, which we include to account for time-varying factors affecting the response variable of interest. Fixed effects represents state and project subcategory $\times$ yearmonth (or state, project subcategory, and year-month) fixed effects. ${ }^{22}$ Detailed variable definitions are provided in Appendix B.

The inclusion of state fixed effects allows us to control for time-invariant state-level factors potentially affecting the likelihood of project success. Project subcategory $\times$ year-

\footnotetext{
${ }^{21}$ This is also evidenced by comments on delayed projects, where backers often quote Kickstarter's terms of use and sometimes threaten creators with litigation. For example on March 23, 2018 a backer of Eye-Smart Android Case for iPhone writes "I invoke my rights under Kickstarter's Terms of Use [...] Project Creators are required to fulfill all rewards of their successful fundraising campaigns or refund any Backer whose reward they do not or cannot fulfill [...] I demand a full refund for my pledge amount ASAP."

${ }^{22}$ The main effects of Treated and Post are not included in equation (1) because they are perfectly collinear with state and subcategory $\times$ year-month fixed effects, respectively. We rely on Kickstarter's project subcategory classification. Kickstarter classifies projects into 51 subcategories, which represent finer partitions of the project categories presented in Table 1, Panel C.
} 
month fixed effects account for unobservable heterogeneity in time-varying project subcategory characteristics that are likely to explain variation in both project success and disclosure. We draw statistical inferences based on standard errors clustered at the project state and year-month level. ${ }^{23}$ Our main coefficient of interest in equation (1) is $\beta_{5}$. If, as we predict, the perceived credibility of project disclosure increases when state-level consumer protection laws are stricter following the change in Kickstarter's terms of use, then $\beta_{5}$ should be positive.

Unobservable state time-varying factors may potentially present a challenge to our identification strategy. These factors could bias our inferences if correlated with the treatment (i.e., with the timing of the change in Kickstarter's terms of use and with the strength of statelevel consumer protection laws). We employ several strategies to alleviate this potential concern (see Section 4.4).

A further challenge may come from changes in unobservable project characteristics around the introduction of the new terms of use. To bias our treatment effect however, these changes would have to systematically vary with the stringency of consumer protection laws across states and correlate with both project funding and disclosure. To mitigate this concern, we nonetheless control for project subcategory $\times$ year-month fixed effects, as well as for a host of project-specific characteristics. Moreover, our analysis of disclosure attributes discussed in Section 4.8 further allays the potential concern that the documented increase in the association between disclosure and project success might simply reflect an improvement in project quality, rather than a change in disclosure attributes.

\footnotetext{
${ }^{23}$ We cluster standard errors at the project state and year-month level because our treatment varies across states and over time.
} 


\subsection{Descriptive Evidence on the Association between Project Success and Disclosure}

To provide initial descriptive evidence of the role of disclosure on Kickstarter, we examine the association between disclosure and project success. Whether creator disclosures facilitate contracting between backers and creators is ex ante unclear. On the one hand, project rewards are one of the main reasons backers participate in reward crowdfunding (Gerber, 2012) and, therefore, backers should factor in their decision to pledge any information that is relevant to estimate the probability that rewards will be delivered. On the other hand, disclosures in this market may not be credible because: (i) disclosures are, to a large extent, voluntary and unverifiable; (ii) most backers only access the platform once; and (iii) there is substantial regulatory uncertainty. However, certain features of reward crowdfunding may render disclosures credible even in the absence of regulation. To the extent that Kickstarter creators are interested in assessing demand for their products and increasing subsequent sales, they have an incentive to disclose truthfully. This, in turn, alleviates moral hazard and prevents market failure (e.g., Strausz, 2017; Gutiérrez and Sáez, 2018).

Table 2 presents the results of the tests that examine the association between disclosure and project success. We focus on two disclosure proxies: the length of the campaign pitch (Ln(Campaign Pitch)) and the length of the risks and challenges section (Ln(Risks and Challenges)). We also consider two main measures of project success: an indicator variable equal to one if a project's funding goal is reached (Funded) and the natural logarithm of the amount pledged to a project (Ln(Pledged)).

We control for several project characteristics, such as a project's funding goal $(\operatorname{Ln}(\mathrm{Goal}))$, the duration of the funding period $(\operatorname{Ln}($ Duration $))$, whether a project is chosen by Kickstarter as a "project of the day" (Project of the Day), whether a project has multiple creators (Multiple Creators), and the number of project rewards 
$(\operatorname{Ln}($ Rewards $)) .{ }^{24} \mathrm{We}$ also control for creator characteristics, such as the length of a creator biography (Ln(Bio Length)), the number of Kickstarter projects backed by a creator (Ln(Projects Backed)), and the number of friends a creator has on Facebook (Ln(Facebook Friends)). Finally, we control for an extensive set of time-varying macro factors, including state per capita GDP $(G D P)$, whether a project is in a high-trust region (Trust), regional internet access (Internet Access), extent of credit constraints (Credit Constraints), and Kickstarter funding performance in the previous year (Funding Performance).

Panel A presents the results of the analysis where the dependent variable is Funded. Columns (1), (3), and (5) display coefficient estimates (and respective $z$-statistics) of logistic regressions including subcategory, state, and year-month fixed effects. The remaining columns display the results from the estimation of linear probability models in which we replace subcategory and year-month fixed effects with subcategory $\times$ year-month fixed effects (Columns (2), (4), and (6)) to account for unobservable time-varying subcategory factors.

Consistent with prior research (e.g., Qiu, 2013; Barbi and Bigelli, 2017), projects with shorter funding periods, lower funding goals, multiple creators, multiple rewards, and projects that are selected by Kickstarter as "project of the day" are more likely to be successful. ${ }^{25}$ Longer creator biographies and creator social capital (proxied by the number of Facebook friends and the number of projects previously backed by a creator) are also associated with higher likelihood of success, in line with Lin et al. (2013), Mollick (2014), Kim et al. (2015), and Koch and Siering (2015). As expected, state per capita GDP, trust, internet access, and lagged Kickstarter funding performance exhibit positive associations

\footnotetext{
${ }^{24}$ In additional sensitivity analyses (untabulated), we re-run our main tests also controlling for the number of videos and images on projects' webpages and continue to find a significant association between disclosure and project success.

${ }^{25}$ The positive coefficient on Multiple Creators is also consistent with a widespread consensus that the performance of new ventures is higher when these are launched by teams as opposed to individuals, a consensus recently challenged by Greenberg and Mollick (2018).
} 
with the likelihood of success in most specifications. The association between bank concentration (our proxy for credit constraints) and the likelihood of success is also positive, although generally not significant. ${ }^{26}$ The different model specifications consistently show a positive association between the likelihood of a project being funded and our disclosure proxies (Ln(Campaign Pitch) and Ln(Risks and Challenges)). The economic magnitude of the association is similar across specifications. As the length of the campaign pitch (risks and challenges section) increases by one standard deviation, the probability of success increases by $1.8(0.8)$ percentage points (based on the coefficients reported in Column (6)). ${ }^{27}$

In Panel $\mathrm{B}$, the dependent variable is instead $\operatorname{Ln}($ Pledged $)$. We find that, across all specifications, amount pledged is robustly associated with disclosure. Specifically, as the campaign pitch (risks and challenges section) increases by one standard deviation, the amount of funds pledged to a project increases by U.S. \$521 (U.S. \$80) or, equivalently, by $29.0 \%(4.5 \%)$ (based on the coefficients reported in Column (3)). ${ }^{28}$ The documented association between disclosure and funding is consistently positive and significant across different project size (i.e., funding goal) categories (see Section 3 of the Online Appendix).

\footnotetext{
${ }^{26}$ The expected sign of the coefficient on this variable is ex-ante unclear. To the extent that bank credit and crowdfunding are substitutes and entrepreneurs rely on Kickstarter (at least in part) to assess demand for their projects, more expensive bank credit may be associated with a composition of projects on Kickstarter that is tilted towards safer projects. It is possible, however, that restrictions to bank credit are also associated with lower availability of funds to backers and hence lower project funding.

${ }^{27}$ To estimate the effect of a standard deviation change in the campaign pitch on the probability of success, we multiply the coefficient on $\operatorname{Ln}$ (Campaign Pitch) by the difference between the logarithm of the average length of the campaign pitch and the logarithm of the average increased by the standard deviation.

${ }^{28}$ To estimate the effect of a standard deviation change in the campaign pitch on the amount of funds pledged to the project, we first set all control variables to their sample means and take the logarithm when applicable. We then compute the corresponding fitted value of Ln(Pledged). Next, we increase Campaign Pitch by its standard deviation, and calculate a new fitted value of Ln(Pledged), leaving the other variables unchanged at their means. The dollar effect of a standard deviation change in the campaign pitch is equal to the difference in the exponentials of the two fitted values. To restate this effect in percentage terms, we divide it by the fitted value of $L n$ (Pledged), calculated based on the average length of Campaign Pitch.
} 


\subsection{Consumer Protection and Disclosure Credibility}

In this section, we employ the research design in the spirit of a DiD described in Section 4.1 to assess whether, subsequent to the change in Kickstarter's terms of use, the perceived credibility of disclosure increases in states with stronger consumer protection laws.

An important identifying assumption in a DiD research design is that, in the absence of treatment, treatment and control groups would exhibit similar trends in the outcome variable of interest (i.e., parallel trends). Because counterfactual trends are not empirically observable, we assess the validity of the parallel-trends assumption by testing for differences in pretreatment trends. We examine differences in disclosure credibility trends across states with varying degrees of consumer protection by mapping out counterfactual treatment effects over our sample period. We map out these effects by replacing Post and its two- and three-way interactions with Disclosure and Treated with four separate time indicators and their respective two- and three-way interactions with Disclosure and Treated in our main model specification. Our treatment effects are captured by the three-way interactions of each of the four separate time indicators with Disclosure and Treated. We plot the estimated treatment effects in Figure 2. The evidence in Figure 2 suggests that, while prior to the rule change the estimated treatment effects are statistically indistinguishable from zero, they experience a sharp increase in the months following the rule change that persists over time. This is the case irrespective of the success and disclosure proxies we use.

Table 3 presents the results from the estimation of equation (1). The dependent variable in Panel A is Funded. We find that, following the change in Kickstarter's terms of use, the association between the likelihood of success and our two measures of disclosure increases, which we interpret as an improvement in the perceived credibility of disclosure. Note that, while the association between the outcome of a funding campaign and disclosure increases following the rule change, it is already significantly positive prior to the rule change, which 
indicates that disclosure was already perceived as credible when the market was largely unregulated. Consistent with our expectations, the increase in the perceived credibility of disclosure is more pronounced in states with stronger consumer protection. This finding is robust to different model specifications and fixed effects structures.

Following the rule change, an increase in the length of the campaign pitch by one standard deviation increases the probability of success by an additional $3.8(0.3)$ percentage points in states where Treated is equal to 16 (1). The negative and significant coefficient on Post $\times$ Treated is also noteworthy. It suggests that, as the risk of litigation increases, projects with relatively lower levels of disclosure experience a decrease in funding. Specifically, in states where Treated is equal to 1, funding decreases for projects with a campaign pitch of less than 99.48 words. In states where Treated is equal to 16, this decrease in funding is observed for projects with a campaign pitch of less than 287.59 words. $^{29}$

In Panel B, the dependent variable is $\operatorname{Ln}($ Pledged $)$. Our coefficient of interest, Disclosure $\times$ Post $\times$ Treated, is again positive and significant for our two disclosure measures, indicating that the elasticity of the amount pledged to the number of words in the campaign pitch and risks and challenges section increases in states with stronger consumer protection following the rule change. This increase ranges from 0.025 (in states where Treated is equal to 1) to 0.400 (in states where Treated is equal to 16) for the campaign pitch (Column (1)) and from 0.023 (in states where Treated is equal to 1) to 0.368 (in states where Treated is equal to 16) for the risks and challenges section (Column (2)). Thus, in states with stricter consumer protection laws, the elasticity of amount pledged to disclosure

\footnotetext{
${ }^{29}$ These estimates are based on the calculation of break-even points. These represent the levels of disclosure that leave the probability of success unchanged following the introduction of the new terms of use. For example, when Treated is equal to 16 , the break-even point is calculated by solving the following equation: $\hat{\beta}_{2} \times 16+$ $\hat{\beta}_{3} \times$ Disclosure $+\hat{\beta}_{5} \times$ Disclosure $\times 16=0$, where $\hat{\beta}_{i}$ are the estimated coefficients reported in Table 3 , Panel A, Column (3).
} 
doubles following the change in Kickstarter's terms of use, again indicating that the increase in the perceived credibility of disclosure is economically meaningful. To further gauge the economic significance of our results, we recast them in U.S. dollars. Following the rule change, an increase in the length of the campaign pitch by one standard deviation increases the amount pledged by an additional U.S. $\$ 730$ (U.S. \$119) in states where Treated is equal to 16 (1). Similarly, an increase in the length of the risks and challenges section by one standard deviation increases the amount pledged by an additional U.S. \$497 (U.S. \$67) in states where Treated is equal to $16(1) .^{30}$

\subsection{Mitigating the Influence of State-Level Time-Varying Factors}

An identification challenge to our research design comes from local shocks at the state level, which may constitute a potential source of omitted variable bias if correlated both with the treatment and the disclosure-funding status relation.

Controlling for time-varying factors potentially affecting the disclosure-funding status relation and Kickstarter's decision to change its terms of use (see Section 2 of the Online Appendix) is especially important because our treatment is concentrated in time. For this reason, in our model specifications, we control for a host of macro factors, such as state per capita GDP, trust, internet access, credit constraints, and Kickstarter funding performance in the previous year. Nevertheless, to further allay the concern that unobservable state-level time-varying factors may confound our results, we conduct a series of additional tests.

First, we limit the sample to shorter time windows of one and two years before and after the rule change. The use of a shorter window mitigates the concern that the effect that we document may be due to other changes taking place during the sample period. Moreover, using a shorter window around the rule change also alleviates the concern that overall

\footnotetext{
${ }^{30}$ Section 4 of the Online Appendix discusses a set of robustness tests that allay potential concerns regarding the identification of a project's state, cancelled and suspended projects, and repeat creators.
} 
changes in market structure (e.g., changes in the type of projects on Kickstarter following the rule change) may be driving our results. As shown in Table 4, Panel A, our coefficient of interest remains positive and significant across all specifications in these shorter windows, with the exception of the regression of probability of success on the length of the risks and challenges section in Column (3), where the coefficient is positive but not significant.

Second, we conduct a county-level analysis (Card and Krueger, 1997; Holmes, 2006; and Dube et al., 2010) in which we restrict the sample to contiguous counties of different states. Assuming that local economic conditions are plausibly similar along a state border, our county-level analysis allows us to exploit discontinuities in the strength of consumer protection across state borders, while effectively controlling for local economic conditions. Figure 3 illustrates the contiguous counties located at U.S. state-border segments and Table 4, Panel B, presents the results of this analysis. Odd-numbered columns include subcategory, county, and year-month fixed effects. Even-numbered columns replace year-month fixed effects by border $\times$ year-month fixed effects. Our main coefficient of interest, Disclosure $\times$ Post $\times$ Treated, remains positive and significant across the different specifications and across the different success and disclosure variables. Furthermore, the magnitude of this coefficient is similar to the coefficient magnitudes reported in previous tables.

Third, we also conduct an additional set of tests in which we impose more stringent fixed effects structures (e.g., statexyear-month fixed effects) effectively subsuming observable and unobservable state-level time-varying factors potentially affecting the disclosure-funding status relation. The results of these tests, presented in Table 4, Panel C, confirm the inferences we draw from our main analysis. ${ }^{31}$

Finally, we follow the approach described in Oster (2019) to assess the stability of our treatment effects and evaluate their robustness to omitted variable bias. The evidence from

\footnotetext{
${ }^{31}$ In this set of tests (Table 4, Panel C), the interaction term Post $\times$ Treated as well as the macro-level control variables are excluded from the model because they are collinear with the state $\times$ year-month fixed effects.
} 
this analysis, discussed in Section 5 of the Online Appendix, suggests that it is unlikely that our treatment effects are driven by omitted variables.

\subsection{Disclosure and Project Backers}

In this section, we examine the effect of the rule change on the number of project backers and their level of engagement. Table 5 presents the results of these analyses. In Panel A, the dependent variable is the natural logarithm of the number of backers (Ln(Backers)). We document a positive and significant association between disclosure and the number of backers before the change in Kickstarter's terms of use. This association increases following the change in Kickstarter's terms of use in states with stricter consumer protection laws, as indicated by the positive coefficient on Disclosure $\times$ Post $\times$ Treated $^{32}$

In Panel B, we separately examine the effects of the change in regulation on the number of new and returning backers. We find that, following the change in Kickstarter's terms of use, the elasticity of the number of both types of backers to disclosure increases, suggesting that disclosure plays an increasingly important role not only in retaining existing Kickstarter users, but also in attracting new backers to the platform.

In Panel $\mathrm{C}$, we examine the effect of the rule change on the level of backer engagement, namely on the extent to which backers comment on a project's page. Backer comments are a form of third-party endorsement (Courtney et al., 2017) and often provide valuable feedback to creators, enabling the development of a virtual community and of a social buzz around the project (Belleflamme et al., 2015). Therefore, a large number of backers supporting and engaging with a particular project campaign can be regarded as a signal of project success. We consider backers that frequently invest on the platform (i.e., superbackers) separately.

\footnotetext{
${ }^{32}$ The increase in the elasticity of the number of backers to the length of the campaign pitch (risks and challenges section) ranges from $0.015(0.012)$ in states where Treated is equal to 1 to $0.240(0.192)$ in states where Treated is equal to 16 . Following the rule change, an increase in the length of the campaign pitch by one standard deviation increases the number of backers by an additional 1 (8) backer(s) in states where Treated is equal to $1(16)$.
} 
Superbackers are perceived as the most experienced and sophisticated funders. They may thus play a role similar to that of institutional investors in traditional equity and credit markets; pledges made by superbackers and their active engagement may be regarded by other backers as a signal of project quality $(\mathrm{Xu}, 2018)$. Both of our disclosure measures exhibit a significantly positive association with backer and superbacker engagement. Following the change in Kickstarter regulation, this association increases in states with stronger consumer protection, consistent with an increase in the perceived credibility of disclosure in these states.

\subsection{Heterogeneity in Treatment Effects}

In this section, we examine cross-sectional variation in treatment effects. We argue that the effect of state consumer protection laws on perceived disclosure credibility is likely to vary depending on: (i) the size of the claim (i.e., the magnitude of the rewards); and (ii) the efficiency of the courts that enforce those laws (see Iverson (2017) who examines bankruptcy outcomes). This is because it may not be cost-effective for backers to litigate small claims as the potential awards would be insufficient to cover legal fees. While small claimants may be able to seek redress through a class action (which allows a representative plaintiff to bring a lawsuit on behalf of a large number of claimants, effectively aggregating multiple claims), we expect the perceived increase in litigation risk to be more pronounced for projects involving larger rewards. Furthermore, the perceived increase in litigation risk (by creators and backers alike) arguably depends on factors such as the extent of confidence in courts and the degree of court busyness. Specifically, we expect the effect of the rule change on disclosure credibility to be stronger in states whose courts are believed to handle criminal offences in a fairer way. Similarly, we expect the effect to be more pronounced in states whose courts experience a lower case load on average. 
In Table 6, Panel A, we partition projects based on median reward magnitude. The coefficient on Disclosure $\times$ Post $\times$ Treated is positive and significant across all groups as expected (note that small backers may also file suit through a class action) but significantly higher in the subsample of projects with larger rewards.

In Table 6, Panels B and C, we partition projects based on the extent of confidence in courts and the degree of court busyness. We measure confidence in courts based on the General Social Survey. Specifically, we compute the percentage of survey respondents in a project's region that believe that courts in their own region deal with criminals in a fair way. ${ }^{33}$ A region is classified as having low (high) confidence in courts if this percentage is lower (higher) than the median across U.S. regions. We find that the effect of the rule change is significantly lower when confidence in courts is low across all success and disclosure measures, with the exception of the regression of Ln(Pledged) on Ln(Campaign Pitch) where the coefficients on Disclosure $\times$ Post $\times$ Treated are not significantly different across the low and high confidence partitions (Table 6, Panel B). We measure court busyness based on the total caseload per capita of state courts before the change in terms in use. We classify a state court as having low (high) caseload if the respective caseload is below (above) the median across all U.S. states. In Table 6, Panel C, we split the sample based on court caseload. We expect the coefficient on Disclosure $\times$ Post $\times$ Treated to be positive and significant across all groups but significantly lower when the respective state court caseload is high. While the relative magnitudes of coefficients across the different partitions are in line with our expectations across all specifications, their difference is only significant in the regression of Funded on Ln(Campaign Pitch).

Combined, the evidence from our cross-sectional tests allays the potential concern that the increase in disclosure credibility that we document in states with stricter consumer

\footnotetext{
${ }^{33}$ Data for these tests are available at the aggregate level for nine U.S. regions (i.e., New England, Mid-Atlantic, East North Central, West North Central, South Atlantic, East South, West South Central, Mountain and Pacific).
} 
protection after the introduction of Kickstarter's new terms of use is attributable to factors other than the perceived increase in consumer litigation risk.

\subsection{Do Project Backers Increasingly Fall for Cheap Talk After the Rule Change?}

In our main analysis, we show that the introduction of Kickstarter's new terms of use strengthens the association between disclosure and project funding, which we argue is consistent with an improvement in disclosure credibility. However, a potential alternative explanation for this stronger association could be that, after the rule change, project bakers increasingly fall for uninformative or deceitful disclosure.

To alleviate this cheap talk concern, we test whether, after the rule change, the association between disclosure and project quality becomes stronger. We contend that Kickstarter's new terms of use increase litigation risk and, consequently, the cost creators potentially face in case of misreporting. To the extent that, following the rule change, the increase in the cost of deceitful disclosures discourages "bad" project creators from attempting to pool with "good" project creators by misreporting the quality of their projects, disclosure should become more informative of underlying project quality.

Because project quality is ex-ante unobservable, our analysis focuses solely on successfully-funded projects. We gauge project quality based on the number of fraud allegations made by backers in the post-funding period (Suspected Fraud). We expect the association between disclosure and Suspected Fraud (our proxy for poor-quality projects) to become more negative after the rule change in states with stricter consumer protection laws. The results of this analysis are reported in Table 7. The coefficient on Disclosure $\times$ Post $\times$ Treated is negative and significant, which is consistent with disclosure becoming more informative of underlying project quality after the introduction of the new terms of 
use. ${ }^{34}$ This finding is especially interesting, as it suggests that, after the rule change, disclosure increasingly helps backers to distinguish between good and bad projects even within the set of fully-funded projects (i.e., at the intensive margin).

The evidence emerging from this analysis provides reassurance that the stronger association between disclosure and project funding following the change in terms of use is unlikely to be explained by backers increasingly falling for cheap talk. ${ }^{35}$

\subsection{Changes in Disclosure Attributes}

Our empirical findings so far document an increase in the association between disclosure and project success following the change in Kickstarter's terms of use, which we regard as evidence of an improvement in the perceived credibility of disclosure. In this section, we investigate how creators enhance the credibility of their disclosures. To this end, we examine changes in the attributes of project disclosures along six dimensions: (i) length; (ii) readability; (iii) sentiment; (iv) lexical diversity; (v) use of specific terminology (e.g., the use of legal terms (i.e., legalese language)); and (vi) presence of quantitative information. We present the results of our disclosure attribute analysis in Table 8.

Consistent with the idea that the rule change increases the expected benefits of disclosure, we expect that, following the rule change, creators provide longer campaign pitch and risk and challenges disclosures in states with stronger consumer protection regulation. In Column (1) of Panels A and B, we document a positive and significant coefficient on Post $\times$ Treated, in line with our expectations.

\footnotetext{
${ }^{34}$ The positive and significant coefficient on Post $\times$ Treated is also noteworthy. It suggests that, as the risk of litigation increases, projects with relatively lower levels of disclosure are more likely to be of lower quality.

${ }^{35}$ The results reported in Table OA-3 of the Online Appendix, which collectively point to an increase in the sentiment of backers, a lower incidence of delays in delivering rewards, and a decrease in the number of fraudulent projects in states with stricter consumer protection following the change in terms of use, as well as our analysis of the changes in disclosure attributes (see Section 4.8), further mitigate the concern that backers increasingly fall for uninformative or deceitful disclosures after the rule change.
} 
We expect disclosure readability to improve after the rule change, as disclosures that are easier to read and comprehend may be perceived as more credible and informative ( $\mathrm{Li}$, 2008), whereas convoluted disclosures may be perceived as misleading and increase litigation risk if rewards are not delivered on time. We find that, while the readability of the risks and challenges section does not significantly change (Panel B, Column (2)), campaign pitch disclosures on average become more readable (Panel A, Column (2)). ${ }^{36,37}$

Creators may refrain from writing very positive campaign pitches after the rule change and increase the use of negative language in the risks and challenges section to avoid legal liability. However, our results do not support this expectation as disclosure sentiment does not significantly change (Column (3) of Panels A and B). ${ }^{38}$

After the introduction of the new terms of use, we expect creators to provide disclosures with higher information content, use more legalese language, and include more quantitative information in their project descriptions. Empirically, we document an improvement in lexical diversity (Column (4) of Panels A and B), consistent with an increase in the information content of project disclosures. Moreover, we find that, following the rule change, creators increasingly use legal terms (i.e., legalese language) in their campaign pitch (but not in the risks and challenges section) (Column (5) of Panels A and B). ${ }^{39,40}$ Finally, in

\footnotetext{
${ }^{36}$ The number of years of education generally required to understand a text is on average 9.8 and 10.7 for the campaign pitch and risks and challenges section, respectively (untabulated).

${ }^{37}$ We obtain similar results (untabulated) when we use, instead, the Gunning Fog (Gunning, 1968) or the Smog (McLaughlin, 1969) indices as alternative measures of readability. In fact, the Flesch-Kincaid grade level, the Gunning Fog index, and the Smog index are strongly correlated.

${ }^{38}$ Although the overall sentiment does not significantly change, in untabulated analyses we find a significant increase in the use of constraining language (i.e., words such as "commit," "forbid," "impair," "limit," "restrict," etc.) in both the campaign pitch and risks and challenges section following the change in terms of use (Bodnaruk, Loughran and McDonald, 2015).

${ }^{39}$ Our legalese measure has the advantage of being tailored to the language typically used on Kickstarter (Loughran and McDonald, 2015; Loughran and McDonald, 2016) but involves some discretion in compiling the respective list of words. In order to circumvent this potential drawback, we rely on the list of "litigious" words developed by Loughran and McDonald (see Loughran and McDonald, 2011). In untabulated tests, we consistently document a statistically significant increase in litigious language in the campaign pitch, but not in the risks and challenges section.

${ }^{40}$ In Section 6 of the Online Appendix, we provide evidence consistent with creators increasingly using words such as "product," "campaign," "business," "manufacturing," "shipping," "risk," and "documentation" in their
} 
Column (6) of Panels A and B, we document an increase in the extent to which quantitative information is included in both the campaign pitch and risks and challenges disclosures.

Taken together, the results of our disclosure attribute analysis suggest that the documented increase in the association between disclosure and project funding is driven, at least in part, by a change in disclosure attributes.

\subsection{Direct and Indirect Costs of Disclosure}

The documented positive association between project disclosures and funding success raises the question of why not all project creators move to a corner solution of maximum disclosure. When deciding on project disclosures, creators trade off the benefits of disclosing additional information with: (i) the indirect costs of revealing proprietary information that may be used by other entrepreneurs (i.e., proprietary costs of disclosure) ${ }^{41}$ and (ii) the direct costs of having, for example, to communicate with more potential backers.

In Table 9, Panel A, we examine the role of proprietary costs of disclosure. We contend that, following the change in Kickstarter's terms of use, creators of more innovative projects face higher proprietary costs of disclosure. Accordingly, we expect the effect of the rule change on the length of the campaign pitch and risk and challenges section to vary with the degree of project innovation. We measure project innovation using a dictionary of words developed by Mukherjee et al. (2017). Based on this dictionary, we assess whether creators make claims that their projects are "novel" and accordingly partition our sample projects into two subsamples.

campaign pitches, and words such as "report," "accountability," "learn," “check," "questions," and "campaign" in the risks and challenges section following the change in terms of use.

${ }^{41}$ See Quartz, Your brilliant Kickstarter idea could be on sale in China before you've even finished funding it, October 16, 2016 (available at: https://qz.com/771727/chinas-factories-in-shenzhen-can-copy-products-atbreakneck-speed-and-its-time-for-the-rest-of-the-world-to-get-over-it/). The article describes a campaign launched in December 2015 by an Israeli entrepreneur for a smartphone case that unfolds into a selfie stick. One week after the campaign was launched, the entrepreneur found a cover with the same design he created on sale on AliExpress, Alibaba's English-language wholesale website. 
For less innovative projects, the coefficient on the interaction term Post $\times$ Treated is positive and significant irrespective of the disclosure proxy we use (i.e., length of campaign pitch (Column (1)) or risks and challenges section (Column (3))). In contrast, for more innovative projects, while the coefficient on the interaction term Post $\times$ Treated is always positive (Columns (2) and (4)), it is only significant when the disclosure proxy is the length of campaign pitch (Column (2)). Most importantly, we find a less pronounced increase in disclosure for more innovative projects (albeit not significantly so in the case of risks and challenges). This evidence is consistent with creators of more innovative projects trading off the benefits of disclosure against the potential costs of being copied by other entrepreneurs. ${ }^{42}$

In Table 9, Panel B, we examine the role of direct costs of disclosure with a specific focus on communication costs. We expect that, after the rule change, project creators incur higher communication costs as a result of having to engage more frequently with a larger number of backers. We use three measures to gauge these communication costs. First, we construct a measure of creator involvement, which captures the frequency with which creators log into Kickstarter's website. Second, we count the number of replies to backer comments by creators (or their collaborators). Third, we measure the length of these replies. Irrespective of the disclosure proxy we use, we find that disclosure is associated with higher creator involvement, as well as with more and longer replies to backers (as suggested by the positive and significant coefficient on Disclosure). Most importantly, these communication costs significantly increase after the rule change in states with stricter consumer protection, as evidenced by the positive and significant coefficient on Disclosure $\times$ Post $\times$ Treated.

\footnotetext{
${ }^{42}$ Proprietary costs are arguably less relevant for information disclosed in the risks and challenges section. Therefore, the fact that the change in risks and challenges disclosures does not differ across more and less innovative projects is not surprising and further reassures us that the differential effect of the change in terms of use on the campaign pitch across more and less innovative projects is likely explained by proprietary costs considerations.
} 
Collectively, the results of these tests provide important evidence on the direct and indirect costs of disclosure and shed light into why not all creators may want to (equally) expand their disclosures following the introduction of the new terms of use.

\section{Conclusion}

We investigate how the interplay of disclosure and regulation shapes capital allocation in reward crowdfunding. Using data from Kickstarter, we show that, even in the absence of regulation and enforcement, disclosure helps creators access capital for their projects, which suggests that disclosure mitigates moral hazard and adverse selection. Most importantly, we find that disclosure becomes more credible (i.e., more strongly associated with funding success) as the potential litigation cost of false and misleading disclosure increases. This effect is more pronounced for U.S. states with stricter consumer protection laws. Also, we provide evidence of substantial heterogeneity in treatment effects: the increase in the perceived disclosure credibility is stronger for projects involving larger rewards, as well as in states whose courts are generally believed to handle criminal cases in a fairer way and, to a lesser extent, in states whose courts are less busy. Furthermore, we show that, following the change in Kickstarter's terms of use, disclosures become longer, easier to read, more informative, and contain more quantitative information and legal terms. Finally, we provide evidence consistent with proprietary and communication costs of disclosure playing an important role in this market. These findings are likely to be of interest to project backers, creators, reward crowdfunding platforms, and regulators alike.

In closing, a few caveats are in order. First, while in our analysis we control for a host of macroeconomic factors, because our treatment is concentrated in time, we cannot entirely rule out the possibility that other concurrent events may also affect the disclosure-funding relation. Second, as our analysis mainly focuses on a specific benefit of disclosure (i.e., the amount of funding a project receives on Kickstarter), our findings can only indirectly speak 
to other potential benefits of disclosure, such as improved project visibility. Relatedly, we cannot observe the amount of funding that projects subsequently raise outside the platform (e.g., from venture capitalists) or whether these projects eventually become viable businesses. Future research could examine the extent to which more transparent Kickstarter projects are more likely to later develop into profitable companies, spur product innovation, and ultimately contribute to economic growth and employment. 


\section{References}

Agrawal, A., C. Catalini, and A. Goldfarb. 'Some simple economics of crowdfunding.' Innovation Policy and the Economy 14 (2014): 63-97.

Akerlof, G. 'The market for lemons: Qualitative uncertainty and the market mechanism.' Quarterly Journal of Economics 84 (1970): 488-500.

Barbi, M., and M. Bigelli. 'Crowdfunding practices in and outside the US.' Research in International Business and Finance 42 (2017): 208-223.

Belleflamme, P., N. Omrani, and M. Peitz. 'The economics of crowdfunding platforms.' Information Economics and Policy 33 (2015): 11-28.

Black, S., and P. Strahan. 'Entrepreneurship and bank credit availability.' Journal of Finance 57 (2002): 2807-2833.

Bodnaruk, A., T. Loughran, and B. McDonald. 'Using 10-K text to gauge financial constraints.' Journal of Financial and Quantitative Analysis 50 (2015): 623-646.

Bourveau, T., E. T. DeGeorge, A. Ellahie, and D. Macciocchi. 'Information intermediaries in the crypto-tokens market.' (2019). Working paper. Available at: https://papers.ssrn.com/sol3/papers.cfm?abstract_id=3193392.

Brüggemann, U., A. Kaul, C. Leuz and I. Werner. 'The twilight zone: OTC regulatory regimes and market quality.' Review of Financial Studies 31 (2017): 898-942.

Card, D., and A. Krueger (1997). 'Myth and measurement: The new economics of the minimum wage.' Princeton University Press, Princeton.

Cetorelli, N., and P. Strahan. 'Finance as a barrier to entry: Bank competition and industry structure in local US markets.' Journal of Finance 61 (2006): 437-461.

Chemla, G., and K. Tinn. 'Learning through crowdfunding.' (2018). Working paper. Available at: https://papers.ssrn.com/sol3/papers.cfm?abstract_id=2796435.

Christensen, H., L. Hail, and C. Leuz. 'Capital-market effects of securities regulation: Prior conditions, implementation, and enforcement.' Review of Financial Studies 29 (2016): 28852924.

Courtney, C., S. Dutta, and Y. Li. 'Resolving information asymmetry: Signaling, endorsement, and crowdfunding success.' Entrepreneurship Theory and Practice 41 (2017): 265-290.

Dube, A., T.W. Lester, and M. Reich. 'Minimum wage effects across state borders: Estimates using contiguous counties.' Review of Economics and Statistic 92 (2010): 945-964.

Ganatra, J. H. 'When a Kickstarter stops: Exploring failures and regulatory frameworks for the Rewards-Based Crowdfunding Industry.' Rutgers University Law Review 68 (2016): 14251472.

Gerber, E., J. Hui, and P. Kuo. 'Crowdfunding: Why people are motivated to post and fund projects on crowdfunding platforms.' Proceedings of the International Workshop on Design, Influence, and Social Technologies: Techniques, Impacts and Ethics 2 (2012).

Gigler, F. 'Self-enforcing voluntary disclosures.' Journal of Accounting Research 32 (1994): 224-240.

Goshen, Z., and G. Parchomovsky. 'The essential role of securities regulation.' Duke Law Journal 55 (2006): 711-782.

Greenberg, J., and E. Mollick. 'Sole survivors: Solo ventures versus founding teams.' (2018). Working paper. Available at: https://papers.ssrn.com/sol3/papers.cfm?abstract_id=3107898.

Grossman, S. 'The role of warranties and private disclosure about product quality.' Journal of Law and Economics 24 (1981): 461-483. 
Gunning, R. 'The technique of clear writing.' New York: McGraw-Hill (1968).

Gutiérrez, M., and M. I. Sáez. 'The promise of reward crowdfunding.' (2018). Working paper. Available at: https://papers.ssrn.com/sol3/papers.cfm?abstract_id=3096753.

Heminway, J. M. 'The legal regulation of US crowdfunding: An organically evolving patchwork.' (2017). Working paper. Available at: https://papers.ssrn.com/sol3/papers.cfm?abstract_id=3061552.

Holmes, T. J. 'Geographic spillover of unionism.' (2006). Working paper. Available at: http://www.nber.org/papers/w12025.

Iverson, B. 'Get in line: Chapter 11 restructuring in crowded bankruptcy courts.' Management Science (2017).

Jarvis, S. 'Defining and measuring lexical diversity.' Vocabulary knowledge: Human ratings and automated measures 47 (2013). John Benjamins Publishing Company.

Kim, J., P. Newberry, and C. Qiu. 'An empirical analysis of a crowdfunding platform.' (2015). Working paper. Available at: https://papers.ssrn.com/sol3/papers.cfm?abstract_id=2672075.

Kincaid, J. P., R. P. Fishburne, R. L. Rogers and B. S. Chissom. 'Derivation of new readability formula for navy enlisted personnel.’ Millington, TN: Navy Research Branch (1975).

Koch, J., and M. Siering. 'Crowdfunding success factors: the characteristics of successfully funded projects on crowdfunding platforms.' (2015). Proceedings of the 23rd European Conference on Information Systems.

Leuz, C. 'Evidence-based policymaking: Promise, challenges and opportunities for accounting and financial markets research.' Accounting and Business Research 48 (2018): 582-608.

Leuz, C., and P. D. Wysocki. 'The economics of disclosure and financial reporting regulation: Evidence and suggestions for future research.' Journal of Accounting Research 54 (2016): 525622.

Li, F. 'Annual report readability, current earnings, and earnings persistence.' Journal of Accounting and Economics 45 (2008): 221-247.

Lin, M., N. R. Prabhala, and S. Viswanathan. 'Judging borrowers by the company they keep: Friendship networks and information asymmetry in online peer-to-peer lending.' Management Science 59 (2013): 17-35.

Lin, T., and V. Pursiainen. 'Fund what you trust? Social capital and moral hazard in crowdfunding.' (2018). Working paper. Available at: https://papers.ssrn.com/sol3/papers.cfm?abstract_id=3088905.

Loughran, T., and B. McDonald. 'When is a liability not a liability? Textual analysis, dictionaries, and 10-Ks.' Journal of Finance 66 (2011): 35-65.

Loughran, T., and B. McDonald. 'The use of word lists in textual analysis.' Journal of Behavioral Finance 16 (2015): 1-11.

Loughran, T., and B. McDonald. 'Textual analysis in accounting and finance: A survey.' Journal of Accounting Research 54 (2016): 1187-1230.

McLaughlin, G. H. 'SMOG grading-A new readability formula.' Journal of Reading 12 (1969): 639-646.

Mahoney, P. 'The development of securities law in the United States.' Journal of Accounting Research 47 (2009): 325-347.

Michels, J. 'Do unverifiable disclosures matter? Evidence from peer-to-peer lending.' The Accounting Review 87: 1385-1413. 
Milgrom, P. 'Good news and bad news: Representation theorems and applications.' Bell Journal of Economics 12 (1981): 380-391.

Mollick, E. 'The dynamics of crowdfunding: An exploratory study.' Journal of Business Venturing 29 (2014): 1-16.

Mollick, E. 'Delivery rates on Kickstarter.' (2015). Working paper. Available at: https://papers.ssrn.com/sol3/papers.cfm?abstract_id=2699251.

Mollick, E., 'Containing multitudes: The many impacts of Kickstarter funding.' (2016). Working paper. Available at: https://papers.ssrn.com/sol3/papers.cfm?abstract_id=2808000.

Mukherjee, A., C. Yang, P. Xiao, and A. Chattopadhyay. 'Does the crowd support innovation? Innovation claims and success on Kickstarter.' Working paper (2017). Available at: https://papers.ssrn.com/sol3/papers.cfm?abstract_id=3003283.

National Consumer Law Center (2009). 'Consumer protection in the States. A 50-state report on unfair and deceptive acts and practices statutes.' Research report. Available at: http://www.nclc.org/images/pdf/udap/report_50_states.pdf.

Oster, E. 'Unobservable selection and coefficient stability: Theory and evidence.' Journal of Business and Economic Statistics 37 (2019): 187-204.

Qiu, C. 'Issues in crowdfunding: Theoretical and empirical investigation on Kickstarter.' (2013). Working paper. Available at: https://papers.ssrn.com/sol3/papers.cfm?abstract_id=2345872.

Sivakumar, K., and G. Waymire. 'Insider trading following material news events: Evidence from earnings.' Financial Management 23 (1994): 23-32.

Stocken, P. C. 'Credibility of voluntary disclosure.' The RAND Journal of Economics (2000): 359374.

Strausz, R. 'A theory of crowdfunding: A mechanism design approach with demand uncertainty and moral hazard.' American Economic Review 107 (2017): 1430-1476.

$\mathrm{Xu}, \mathrm{T}$. 'Learning from the crowd: The feedback value of crowdfunding.' (2018). Working paper. Available at: https://papers.ssrn.com/sol3/papers.cfm?abstract_id=2637699. 


\section{Appendix A: Consumer Protection Regulation}

\section{A-1. Applicability and Landmark Lawsuits}

There is substantial variation in the scope of consumer protection regulation. While in some states a backer has to be classed as a consumer in a traditional sense, that is, "a person that buys goods and services," in order to be afforded protection under state consumer laws, other states employ broader definitions to encompass, for example, "any person that suffers an ascertainable loss, " in Connecticut, and any private claimant that has suffered damage, in Arizona (Ganatra, 2016).

Nevertheless, litigation may be possible (albeit more difficult) even in states that employ a more traditional consumer definition. This is because, while one might potentially argue that backers are not consumers and rewards are simply a token incentive to donate, pledges made on reward crowdfunding platforms are generally construed as "pre-purchases" (Hemingway, 2017). This was in fact the view taken by the Federal Trade Commission (FTC) in its 2015 action against Erik Chevalier, who ran a Kickstarter campaign to raise funds to produce a board game. Paragraph 10 of the FTC complaint clearly states: "Crowdfunding transactions typically involve consumers (sometimes known as "backers") giving money (known as a "pledge") to a project "creator" in exchange for a specific "reward"." As a result, false and misleading disclosures regarding the product and the failure to deliver rewards or refund backers were deemed a violation of the FTC Act and the defendant was ordered to pay U.S. $\$ 111,794 .^{43}$

A similar view was taken by the Washington State Attorney General, Bob Ferguson who, in 2015, successfully charged Ed Nash and his company, Altius Management, because of the Asylum Playing Cards Kickstarter campaign: "Washington state will not tolerate crowdfunding theft. If you accept money from consumers, and don't follow through on your

\footnotetext{
43 The FTC complaint against Erik Chevalier specifically refers to misrepresentation and deceptive disclosure: "the representation as set forth in Paragraph 33 was and is false and misleading, and constitutes a deceptive act or practice in violation of Section 5(a) of the FTC Act, 15 U.S.C. $\S$ 45(a)" (Available at: https://www.ftc.gov/system/files/documents/cases/150611 chevaliercmpt.pdf).
} 
obligations, my office will hold you accountable." As a result of the suit, Ed Nash was ordered to pay U.S. \$54,851 for violating the state Consumer Protection Act. Similarly, in September 2016 the Oregon State Attorney General confirmed that she was conducting an investigation into the Coolest Cooler campaign (which raised U.S. \$13.2 million from 62,642 backers on Kickstarter). In June 2017 Coolest Cooler reached a settlement with the Oregon Department of Justice. ${ }^{44}$

\section{A-2. Heterogeneity in Strength of State Consumer Protection Laws}

U.S. states have their own consumer protection laws, the Unfair and Deceptive Acts and Practices (UDAP) statutes. These represent the main line of defense to protect consumers from predatory and deceptive business practices. The strength of UDAP statutes varies extensively from state to state along several dimensions.

First, while some states broadly prohibit deception and/or unfairness, others confine the prohibition to a defined list of specific practices, making it harder to tackle new methods of deception and unfairness as they emerge. Also, some states prohibit acts that are deceptive, but not acts that are unfair, encompass very narrow types of deception and unfairness, or employ a very narrow consumer definition. Second, some states exempt specific industries (e.g., banks, insurers, regulated industries) from UDAP statutes. Third, while most state agencies have the authority to seek an injunction, restitution for consumers or civil penalties, several states limit the effectiveness of these forms of relief, namely by requiring the state agency to prove intent before seeking an injunction (e.g., Colorado, Indiana, Nevada, North Dakota, and Wyoming), prohibiting state agencies from seeking civil penalties (e.g., Rhode Island), or severely limiting the amount of civil penalties that can be sought (e.g., District of

\footnotetext{
${ }^{44}$ In addition to agreeing to provide a certain number of coolers to its backers, the company was required to set aside $10 \%$ of its profits from future sales to fulfill commitments to other backers. The company: (i) agreed to pay U.S. $\$ 20$ per cooler to all backers who do not receive their product by the middle of 2020; (ii) was forbidden from using rewards-based crowdfunding sites until all commitments to backers have been met; (iii) was required to submit financials to an outside accountant quarterly and to provide the Department of Justice access to financial records and progress reports; and (iv) was ordered to pay a fine of U.S. $\$ 50,000$.
} 
Columbia, Missouri, Pennsylvania, and Tennessee). Fourth, while in some states consumers can effectively supplement public enforcement by taking a business to court and seeking restitution and punitive damages, this is not as easy (or even impossible) in other states. For example, several states prohibit class action lawsuits, others require consumers to pay defendants attorney fees even if the suit is filed in good faith, and several prohibit enhanced damages (which would allow consumers to seek two or three times their actual damages). In contrast, in other states consumer regulation is stricter with laws allowing, for example, consumer lawsuits without pre-suit notice and proof of public impact, as well as class actions. In sum, there is considerable variation across states in the likelihood and expected outcomes of consumer litigation.

\section{A-3. State Consumer Protection Index}

The heterogeneity in the strength of state consumer protection laws is highlighted by the National Consumer Law Center in their publication titled "Consumer Protection in the States: A 50-State Report on Unfair and Deceptive Acts and Practices Statutes."

The report evaluates consumer protection laws in each U.S. state and the District of Columbia along four broad dimensions: their substantive prohibitions, their scope, the remedies they provide for the state enforcement agency, and the remedies they provide for consumers (see Table A-1).

For each dimension, the strength of Unfair and Deceptive Acts and Practices Statutes (UDAP) statutes is rated as "weak," "mixed or undecided" and "strong." We first convert these qualitative attributes into numerical ratings taking the values of $-1,0$, and 1 if a dimension is rated as "weak," "mixed or undecided," or "strong," respectively. We then add these numerical ratings across all dimensions to form a summary state-level index. Table A-2 presents descriptive information (for each U.S. state and the District of Columbia) on the consumer protection index. 


\section{Table A-1: Dimensions of State-Level Consumer Protection Regulation}

Prohibition of unfairness, deception

Broad deception prohibition

Broad unfairness prohibition

Rulemaking authority

Scope

Covers credit

Covers insurance

Covers utilities

Covers post-sale acts

Covers real estate

State enforcement

Civil penalty amount

Deception sufficient without proof of intent or knowledge

Remedies for consumers

Compensatory damages for consumers

Multiple or punitive damages

Attorney fees for consumers

Class actions

Allows consumer suit without proof of public impact

Allows consumer suit without pre-suit notice

This table presents the different dimensions of state-level consumer protection regulation analyzed by the National Consumer Law Center in their report titled "Consumer Protection in the States: A 50-State Report on Unfair and Deceptive Acts and Practices Statutes." For each dimension, the strength of Unfair and Deceptive Acts and Practices Statutes (UDAP) statutes is rated as "weak," "mixed or undecided," or "strong." 
Table A-2: Strength of Consumer Protection Regulation by U.S. State

\begin{tabular}{|c|c|}
\hline State & Consumer Protection Index \\
\hline Alabama & 1 \\
\hline Alaska & 8 \\
\hline Arizona & 7 \\
\hline Arkansas & 7 \\
\hline California & 11 \\
\hline Colorado & 7 \\
\hline Connecticut & 15 \\
\hline Delaware & 3 \\
\hline District of Columbia & 15 \\
\hline Florida & 4 \\
\hline Georgia & 3 \\
\hline Hawaii & 16 \\
\hline Idaho & 11 \\
\hline Illinois & 14 \\
\hline Indiana & 1 \\
\hline Iowa & 1 \\
\hline Kansas & 10 \\
\hline Kentucky & 9 \\
\hline Louisiana & 7 \\
\hline Maine & 12 \\
\hline Maryland & 7 \\
\hline Massachusetts & 14 \\
\hline Michigan & 3 \\
\hline Minnesota & 7 \\
\hline Mississippi & 2 \\
\hline Missouri & 12 \\
\hline Montana & 10 \\
\hline Nebraska & 3 \\
\hline Nevada & 9 \\
\hline New Hampshire & 8 \\
\hline New Jersey & 13 \\
\hline New Mexico & 13 \\
\hline New York & 9 \\
\hline North Carolina & 13 \\
\hline North Dakota & 11 \\
\hline Ohio & 9 \\
\hline Oklahoma & 9 \\
\hline Oregon & 9 \\
\hline Pennsylvania & 11 \\
\hline Rhode Island & 6 \\
\hline South Carolina & 7 \\
\hline South Dakota & 5 \\
\hline Tennessee & 7 \\
\hline Texas & 9 \\
\hline Utah & 7 \\
\hline Vermont & 15 \\
\hline Virginia & -1 \\
\hline Washington & 8 \\
\hline West Virginia & 8 \\
\hline Wisconsin & 12 \\
\hline Wyoming & 3 \\
\hline
\end{tabular}

This table provides descriptive information (for each U.S. state and the District of Columbia) on the consumer protection index that we use to construct the treatment variable in our analysis (Treated). The index is computed based on the consumer protection regulation report published by the National Consumer Law Center and titled "Consumer Protection in the States: A 50-State Report on Unfair and Deceptive Acts and Practices Statutes." Consumer protection in each state is evaluated according to several dimensions (see Table A-1). For each dimension, the strength of Unfair and Deceptive Acts and Practices Statutes (UDAP) statutes is rated as "weak," "mixed or undecided," or "strong." We first convert these qualitative attributes into numerical ratings taking the values of $-1,0$, and 1 if a dimension is rated as "weak," "mixed or undecided," or "strong," respectively. We then add these numerical ratings across all dimensions to form a summary state-level index. 
Appendix B: Variable Definitions

\begin{tabular}{|c|c|}
\hline Variable & Definition \\
\hline \multicolumn{2}{|l|}{ Success Variables } \\
\hline Funded & $\begin{array}{l}\text { Indicator variable set equal to one if the amount pledged by backers is } \\
\text { higher than a project's funding goal, and zero otherwise (Source: } \\
\text { Kickstarter). }\end{array}$ \\
\hline Ln(Pledged $)$ & $\begin{array}{l}\text { Natural logarithm of the amount pledged to a project (Source: } \\
\text { Kickstarter). }\end{array}$ \\
\hline Ln(Backers) & $\begin{array}{l}\text { Natural logarithm of the number of project backers (Source: } \\
\text { Kickstarter). }\end{array}$ \\
\hline Ln(New Backers) & $\begin{array}{l}\text { Natural logarithm of the number of project backers that have not } \\
\text { previously backed other projects on Kickstarter (Source: Kickstarter). }\end{array}$ \\
\hline Ln(Returning Backers) & $\begin{array}{l}\text { Natural logarithm of the number of project backers that have } \\
\text { previously backed other projects on Kickstarter (Source: Kickstarter). }\end{array}$ \\
\hline Ln(Backer Comments) & $\begin{array}{l}\text { Natural logarithm of the length of comments made by backers in a } \\
\text { project's comments tab (Source: Kickstarter). }\end{array}$ \\
\hline Ln(Superbacker Comments) & $\begin{array}{l}\text { Natural logarithm of the length of comments made by superbackers in } \\
\text { a project's comments tab. Superbackers are backers that have } \\
\text { supported more than } 25 \text { projects with pledges of at least U.S. } \$ 10 \text { in } \\
\text { the previous year (Source: Kickstarter). }\end{array}$ \\
\hline \multicolumn{2}{|l|}{$\underline{\text { Disclosure Variables }}$} \\
\hline Ln(Campaign Pitch) & $\begin{array}{l}\text { Natural logarithm of the length of a project's campaign pitch in words } \\
\text { (Source: Kickstarter). }\end{array}$ \\
\hline Ln(Risks and Challenges) & $\begin{array}{l}\text { Natural logarithm of the length of a project's risks and challenges } \\
\text { section in words (Source: Kickstarter). }\end{array}$ \\
\hline Readabiliy & $\begin{array}{l}\text { The additive inverse of the Flesch-Kincaid grade level (Kincaid et al., } \\
\text { 1975) for the campaign pitch and risks and challenges section } \\
\text { (calculated using the R "readability" package). The Flesch-Kincaid } \\
\text { grade level provides an approximation of the number of years of } \\
\text { education required for a reader to be able to parse and comprehend a } \\
\text { text (Source: Kickstarter). }\end{array}$ \\
\hline Sentiment & $\begin{array}{l}\text { Sentiment of the campaign pitch, or risks and challenges section, } \\
\text { calculated as (Number of positive words - Number of negative } \\
\text { words)/(Number of positive words }+ \text { Number of negative words). } \\
\text { Positive and negative words are identified based on Dictionary GI, a } \\
\text { Dictionary with opinionated words from the Harvard-IV dictionary as } \\
\text { in the General Inquirer software (calculated using the R } \\
\text { "SentimentAnalysis" package) (Source: Kickstarter). }\end{array}$ \\
\hline Lexical Diversity & $\begin{array}{l}\text { Carroll's Corrected Type-Token ratio (CTTR) for the campaign pitch } \\
\text { (risks and challenges section), calculated as the ratio of different } \\
\text { unique word stems (types) to the square root of twice the total number } \\
\text { of words (tokens) (Jarvis, 2013) (Source: Kickstarter). }\end{array}$ \\
\hline Legalese & $\begin{array}{l}\text { Indicator variable set equal to one if the campaign pitch (risks and } \\
\text { challenges section) contains legalese language, and zero otherwise. } \\
\text { Please refer to Appendix C for a list of legal terms (Source: } \\
\text { Kickstarter). }\end{array}$ \\
\hline Quantitative Information & $\begin{array}{l}\text { Natural logarithm of the number of numerals, including numbers and } \\
\text { words expressing numbers, in the campaign pitch (risks and challenges } \\
\text { section) (Source: Kickstarter). }\end{array}$ \\
\hline
\end{tabular}

(continued) 


\begin{tabular}{|c|c|}
\hline Variable & Definition \\
\hline \multicolumn{2}{|l|}{$\underline{\text { Project Controls }}$} \\
\hline $\operatorname{Ln}($ Goal $)$ & Natural logarithm of a project's funding goal (Source: Kickstarter). \\
\hline Ln(Duration) & $\begin{array}{l}\text { Natural logarithm of the duration of a project's funding period in days } \\
\text { (Source: Kickstarter). }\end{array}$ \\
\hline Project of the Day & $\begin{array}{l}\text { Indicator variable set equal to one if a project is chosen as "project of } \\
\text { the day" by Kickstarter, and zero otherwise (Source: Kickstarter). }\end{array}$ \\
\hline Multiple Creators & $\begin{array}{l}\text { Indicator variable set equal to one if a project has multiple creators, } \\
\text { and zero otherwise (Source: Kickstarter). }\end{array}$ \\
\hline $\operatorname{Ln}($ Rewards $)$ & $\begin{array}{l}\text { Natural logarithm of the number of project rewards (Source: } \\
\text { Kickstarter). }\end{array}$ \\
\hline \multicolumn{2}{|l|}{$\underline{\text { Creator Controls }}$} \\
\hline Ln(Bio Length) & $\begin{array}{l}\text { Natural logarithm of the length of a project creator biography in words } \\
\text { (Source: Kickstarter). }\end{array}$ \\
\hline Ln(Projects Backed) & $\begin{array}{l}\text { Natural logarithm of the number of Kickstarter projects backed by a } \\
\text { project creator (Source: Kickstarter). }\end{array}$ \\
\hline Ln(Facebook Friends) & $\begin{array}{l}\text { Natural logarithm of the number of Facebook friends of a project } \\
\text { creator (Source: Kickstarter). }\end{array}$ \\
\hline \multicolumn{2}{|l|}{$\underline{\text { Macro Controls }}$} \\
\hline $\operatorname{Ln}(G D P)$ & $\begin{array}{l}\text { Natural logarithm of the real state per capita GDP (chained } 2012 \\
\text { dollars) (Source: Bureau of Economic Analysis). }\end{array}$ \\
\hline Trust & $\begin{array}{l}\text { Indicator variable set equal to one if a project is in a high-trust U.S. } \\
\text { region, and zero otherwise. A U.S. region is classified as high trust if } \\
\text { the percentage of "Yes" answers to the question "Do you think most } \\
\text { people can be trusted?" in each region and year is above the country } \\
\text { median for that year (Source: General Social Surveys, GSS). }\end{array}$ \\
\hline Internet Access & $\begin{array}{l}\text { Percentage of respondents that have a computer at home in a project's } \\
\text { region (Source: General Social Surveys, GSS). }\end{array}$ \\
\hline Credit Constraints & $\begin{array}{l}\text { Degree of bank concentration (Black and Strahan, 2002; Cetorelli and } \\
\text { Strahan, 2006), calculated as the sum of the squared share of deposits } \\
\text { for each banking company in a city (Metropolitan Statistical Area } \\
\text { (MSA)) averaged across all MSAs within a state (Source: Bank Call } \\
\text { Reports, available at the Federal Financial Institutions Examination } \\
\text { Council (FFIEC) website). }\end{array}$ \\
\hline Funding Performance & $\begin{array}{l}\text { Total amount pledged scaled by total funding goal in a project's state } \\
\text { in the previous year (Source: Kickstarter) }\end{array}$ \\
\hline \multicolumn{2}{|l|}{$\underline{\text { Regulation Variables }}$} \\
\hline Post & $\begin{array}{l}\text { Indicator variable set equal to one if a project's funding period starts } \\
\text { after September 19, 2014, and zero otherwise. }\end{array}$ \\
\hline Treated & $\begin{array}{l}\text { Strength of state consumer protection law, reflecting the strength of } \\
\text { state Unfair and Deceptive Acts and Practices (UDAP) statutes in four } \\
\text { broad categories: their substantive prohibitions, their scope, the } \\
\text { remedies they provide for the state enforcement agency, and the } \\
\text { remedies they provide for consumers (Source: Calculated based on the } \\
\text { National Consumer Law Center's report on UDAP, available at: } \\
\text { http://www.nclc.org/images/pdf/udap/report_50_states.pdf). } \\
\text { Appendix A for details. }\end{array}$ \\
\hline
\end{tabular}


Appendix B (continued)

Variable

Cross-Sectional Partition Variables

Reward Magnitude

Confidence in Courts

Caseload

Project Quality Variable

Suspected Fraud

Disclosure Cost Variables

Innovative Project

Creator Involvement

Ln(Creator Replies)

Ln(Creator Replies Length)
Definition

Largest reward offered for a project (Source: Kickstarter).

Percentage of respondents to the General Social Survey in a project's region that believe that courts in their respective area deal well with criminals (i.e., respondents that answer "About right" to the question "In general, do you think the courts in this area deal too harshly or not harshly enough with criminals?") (Source: General Social Survey, available at http://gss.norc.org/).

Total caseload per capita in a project's state courts. The total caseload is the sum of all incoming (newly filed, reopened, and reactivated) cases reported by a state. It comprises civil, domestic relations, criminal, juvenile, and traffic violations cases (Source: Court Statistics Project by the National Center for State Courts, available at http://www.courtstatistics.org/).

Number of fraud allegations made by backers of a successfully-funded project in the comments tab scaled by number of backers. Fraud allegations are identified using the fraud word list presented in Appendix C (Source: Kickstarter).

Indicator variable set equal to one if the campaign pitch includes at least one of the words in the "novel" word list (Mukherjee et al., 2017) presented in Appendix C, and zero otherwise (Source: Kickstarter).

Additive inverse of the number of days from the last creator login to Kickstarter.com to the end of the funding period (Source: Kickstarter).

Natural logarithm of the number of replies to backers by creators and their collaborators (Source: Kickstarter).

Natural logarithm of the length of replies to backers by creators and their collaborators in words (Source: Kickstarter). 


\section{Appendix C: Lists of Words}

\begin{tabular}{l|l}
\hline \hline Variable & Words \\
\hline Delay & Delay (Delays, Delayed, Delaying) \\
& Late \\
\hline Fraud & Fraud (Frauds, Fraudulent, Defraud, Defrauds, Defrauded, Defrauding) \\
& Scam (Scams, Scamming, Scammed, Scammer, Scammers) \\
& Lie (Lies, Lying) \\
& Deceive (Deceives, Deceived, Deceiving) \\
Sham \\
& Hoax \\
& Forgery (Forgeries, Forged, Forging) \\
& Counterfeit (Counterfeits, Counterfeited) \\
& Thief (Thieves, Theft) \\
& Steal (Steals, Stealing, Stole, Stolen) \\
& Mislead (Misleads, Misleading, Misled) \\
& Trickster (Tricksters, Tricking, Tricked) \\
& Fake (Fakes, Faked, Faking) \\
& Charlatan (Charlatans) \\
\hline Legalese & Disclaim (Disclaimer, Disclaiming) \\
& Liability (Liabilities, Liable) \\
& Clause (Clauses) \\
& Comply (Complies, Compliance, Complying) \\
& Legal \\
& Contract (Contracts, Contractual) \\
& Damage (Damages, Damaging) \\
& Law (Laws) \\
& Regulation (Regulations) \\
& Consumer Protection (Consumer Protections, Consumer Law, Consumer Laws, Consumer Right, \\
& Consumer Rights) \\
& Obligation (Obligations, Obliged) \\
& Responsible (Responsibility, Responsibilities) \\
\hline \hline Novel & Avant-Guard \\
& Creative \\
& Distinctive \\
& Groundbreaking \\
Imaginative \\
Ingenious \\
Inventive \\
New \\
Novel \\
Original \\
Remarkable \\
Revolutionary \\
Unique \\
\hline
\end{tabular}


Figure 1: Strength of Consumer Protection Regulation

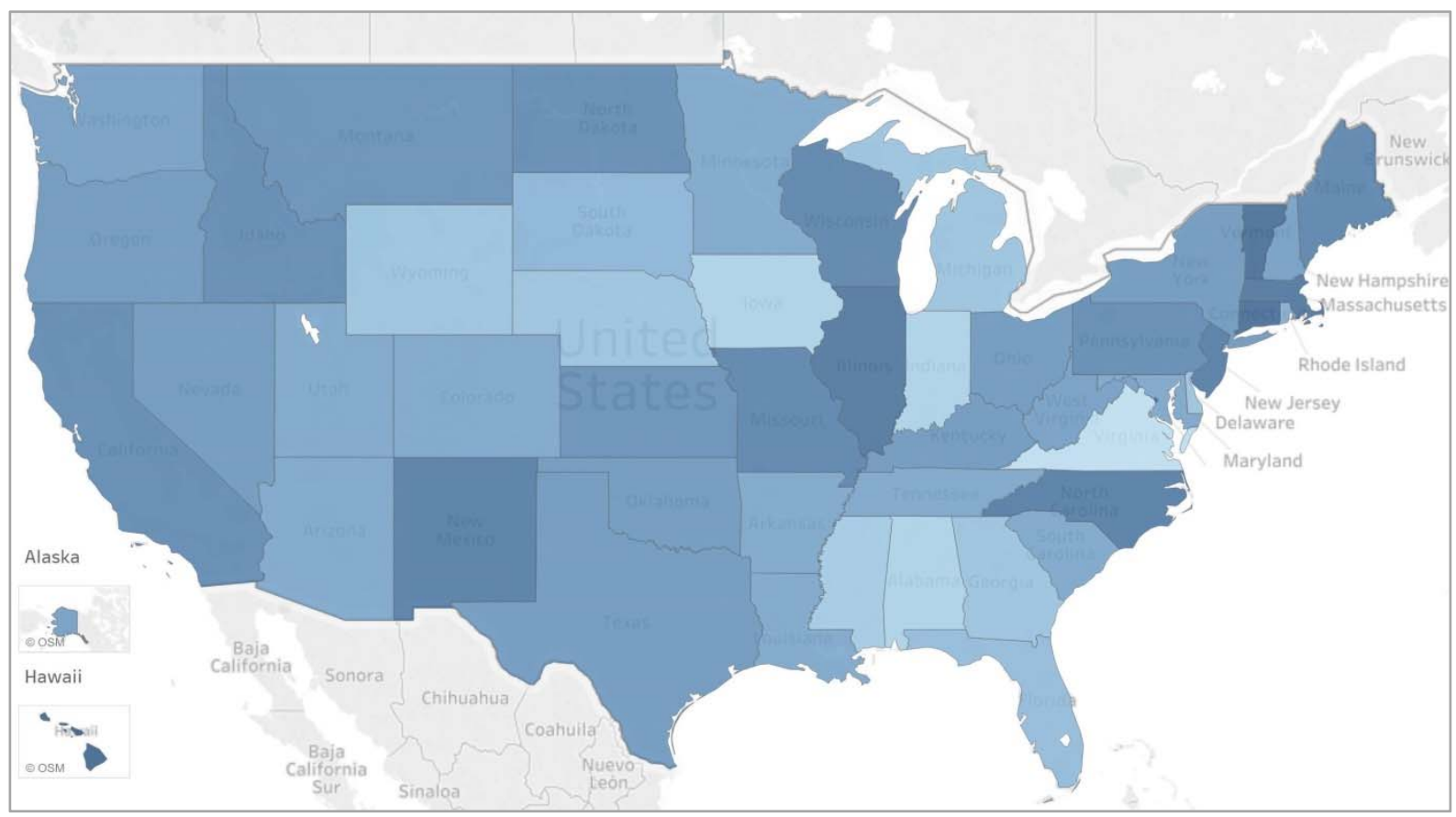

This figure shows the differential strength of consumer protection laws across U.S. states. Dark (light) blue areas indicate stricter (less strict) consumer protection regulation. 


\section{Figure 2: Treatment Effects}

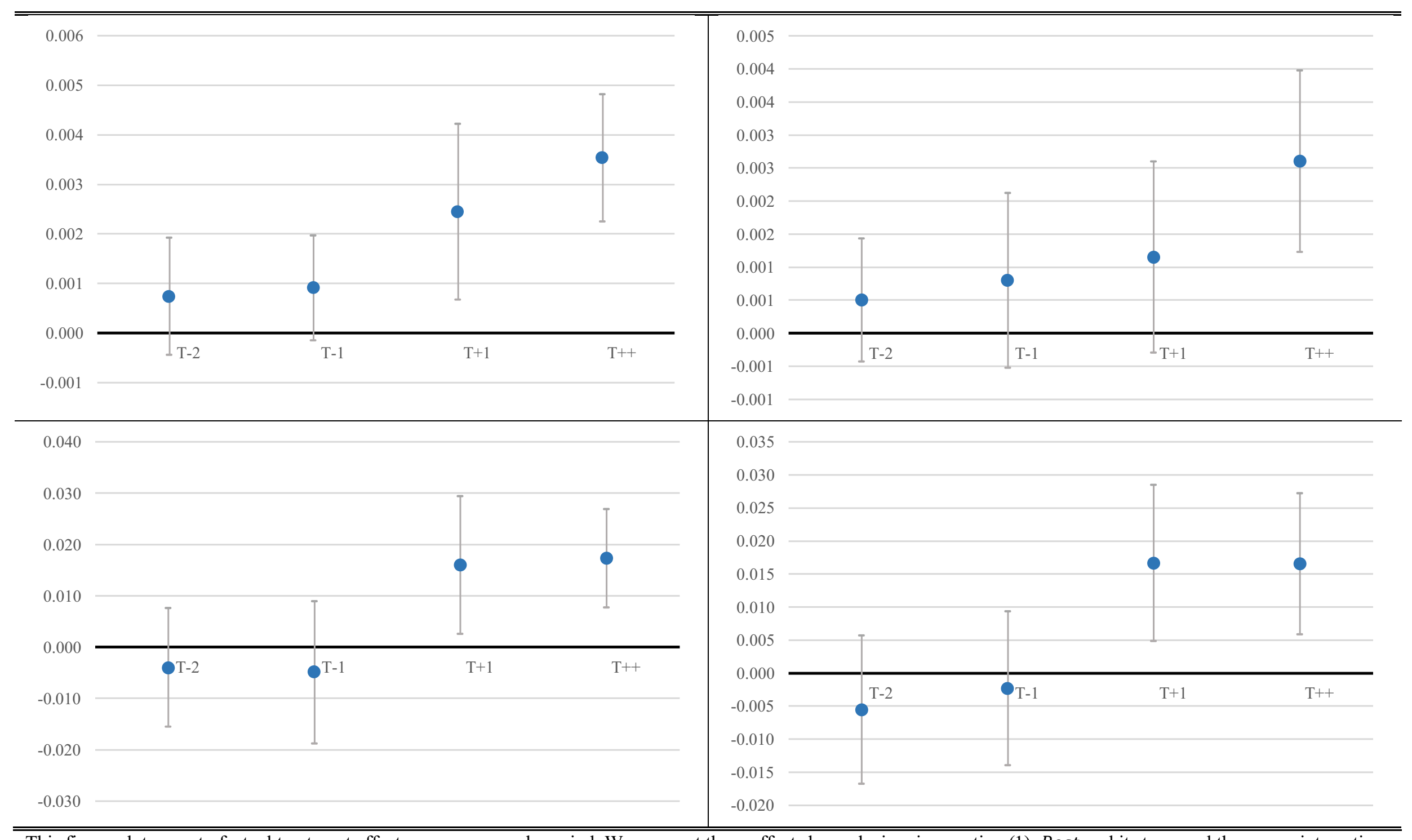

This figure plots counterfactual treatment effects over our sample period. We map out these effects by replacing, in equation (1), Post and its two- and three-way interactions with Disclosure and Treated with four separate time indicators (from January 1, 2013 to June 19, $2013\left(T_{-2}\right)$, from June 20, 2013 to September 19, $2014\left(T_{-1}\right)$, from 
September 20, 2014 to March 19, $2015\left(T_{+1}\right)$ and after March 19, $\left.2015\left(T_{++}\right)\right)$and their respective two- and three-way interactions with Disclosure and Treated. Our treatment effects are captured by the three-way interactions of each of the four separate time indicators with Disclosure and Treated. The upper left (right) plot reports treatment effect estimates and respective $95 \%$ confidence intervals of a model specification in which the dependent variable is Funded and the disclosure variable is Ln(Campaign Pitch) (Ln(Risks and Challenges)). The lower left (right) plot reports treatment effect estimates and respective $95 \%$ confidence intervals of a model specification in which the dependent variables is Ln(Pledged) and the disclosure variable is Ln(Campaign Pitch) (Ln(Risks and Challenges)). Project, creator, and macro-level control variables as well as state and subcategory $\times$ year-month fixed effects are included in all model specifications. 
Figure 3: Border Counties

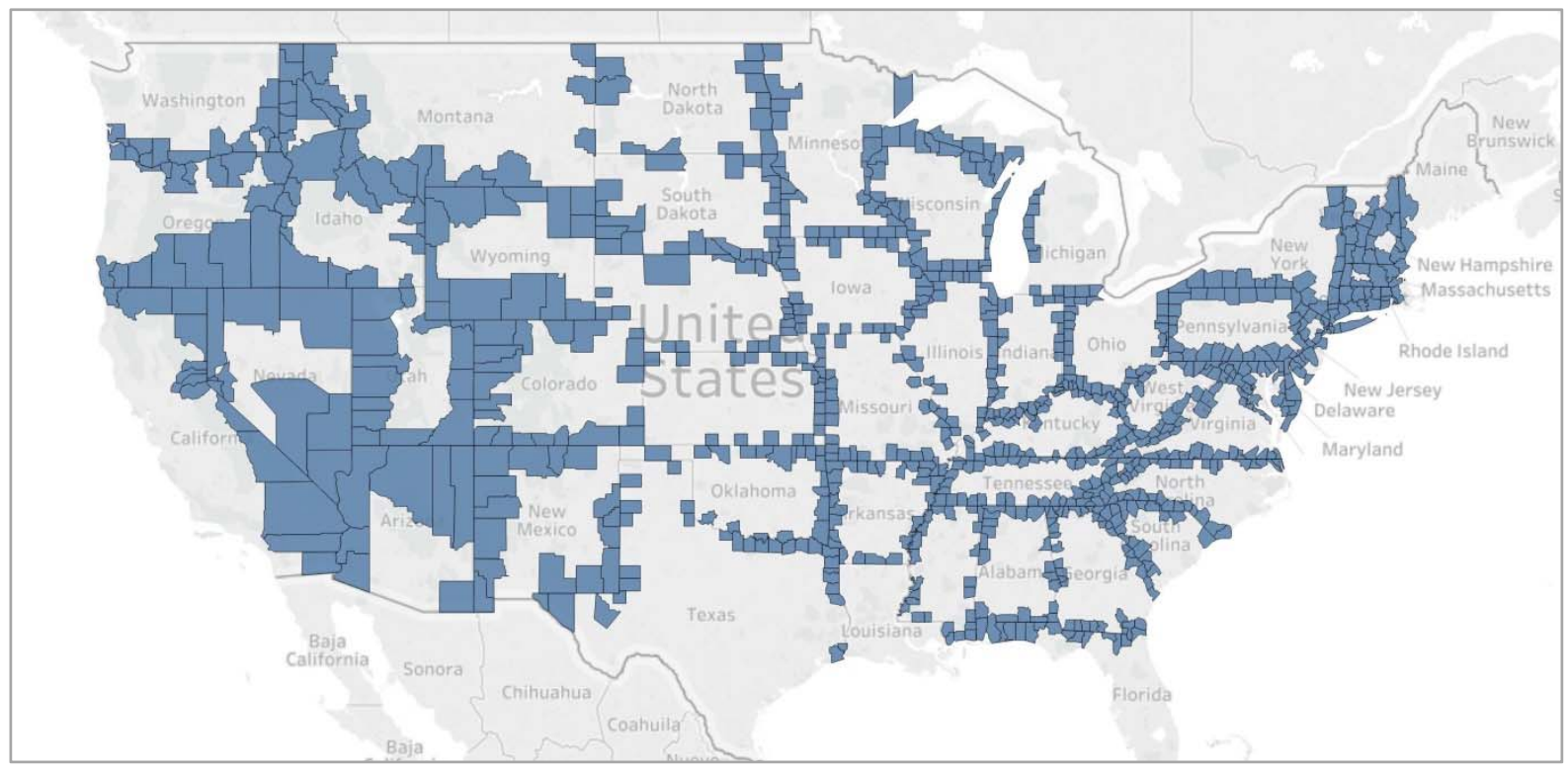

This figure shows contiguous U.S. counties located at state border segments (dark blue areas) that we use in our border county analysis. 
Table 1: Sample Selection and Composition

Panel A: Sample Selection Criteria

Projects downloaded on July 15, 2017

Exclude projects with missing funding period

- Exclude foreign projects

- Exclude projects with missing location state

- Exclude projects with zero funding goal

Panel B: Projects by Year

\begin{tabular}{lrr}
\hline \hline Year & Obs. & $\%$ \\
\hline 2009 & 912 & 0.36 \\
2010 & 8,971 & 3.52 \\
2011 & 25,385 & 9.95 \\
2012 & 39,348 & 15.43 \\
2013 & 38,812 & 15.22 \\
2014 & 50,786 & 19.91 \\
2015 & 46,348 & 18.17 \\
2016 & 30,009 & 11.77 \\
2017 & 14,446 & 5.66 \\
\hline Total & 255,017 & 100.00 \\
\hline \hline
\end{tabular}

Panel C: Projects by Category

\begin{tabular}{lrr}
\hline \hline Category & Obs. & $\%$ \\
\hline Film and Video & 65,363 & 25.63 \\
Music & 30,183 & 11.84 \\
Publishing & 26,866 & 10.53 \\
Games & 21,758 & 8.53 \\
Art & 18,307 & 7.18 \\
Technology & 17,518 & 6.87 \\
Design & 17,386 & 6.82 \\
Food & 15,669 & 6.14 \\
Fashion & 14,273 & 5.60 \\
Comics & 7,954 & 3.12 \\
Photography & 6,593 & 2.59 \\
Crafts & 3,048 & 1.20 \\
Dance & 2,851 & 1.12 \\
Journalism & 2,849 & 1.12 \\
Theatre & 2,301 & 0.90 \\
Craft & 2,098 & 0.82 \\
\hline Total & 255,017 & 100.00 \\
\hline \hline
\end{tabular}

Panel D: Projects by Size

\begin{tabular}{lrr}
\hline \hline Size & Obs. & $\%$ \\
\hline Goal $<$ U.S. $\$ 5,000$ & 108,724 & 42.63 \\
U.S. $\$ 5,000 \leq$ Goal < U.S. \$10,000 & 50,823 & 19.93 \\
U.S. $\$ 10,000 \leq$ Goal < U.S. \$15,000 & 26,528 & 10.40 \\
Goal $\geq$ U.S. $\$ 15,000$ & 68,942 & 27.04 \\
\hline Total & 255,017 & 100.00 \\
\hline \hline
\end{tabular}


Table 1 (continued)

Panel E: Descriptive Statistics

\begin{tabular}{|c|c|c|c|c|c|c|c|c|}
\hline & Obs. & Mean & Std. Dev. & $P 10$ & $P 25$ & Median & $P 75$ & $P 90$ \\
\hline \multicolumn{9}{|l|}{ Success variables: } \\
\hline$\overline{\text { Funded }}$ & 255,017 & 0.386 & 0.487 & 0.000 & 0.000 & 0.000 & 1.000 & 1.000 \\
\hline Pledged & 255,017 & 6,597 & 16,344 & 0 & 281 & 1,691 & 5,442 & 14,000 \\
\hline Backers & 255,017 & 79 & 210 & 0 & 2 & 15 & 61 & 172 \\
\hline New Backers & 255,017 & 27 & 58 & 0 & 0 & 5 & 29 & 71 \\
\hline Returning Backers & 255,017 & 50 & 161 & 0 & 0 & 4 & 26 & 98 \\
\hline Backer Comments & 255,017 & 107 & 294 & 0 & 0 & 0 & 46 & 281 \\
\hline Superbacker Comments & 255,017 & 22 & 86 & 0 & 0 & 0 & 0 & 31 \\
\hline \multicolumn{9}{|l|}{ Disclosure variables: } \\
\hline Campaign Pitch & 255,017 & 585 & 471 & 166 & 266 & 443 & 750 & 1,190 \\
\hline Risks and Challenges & 188,915 & 127 & 88 & 45 & 67 & 103 & 159 & 239 \\
\hline \multicolumn{9}{|l|}{ Project variables: } \\
\hline Goal & 255,017 & 18,124 & 41,167 & 780 & 2,000 & 5,000 & 15,000 & 40,000 \\
\hline Duration & 255,017 & 34 & 13 & 21 & 30 & 30 & 38 & 60 \\
\hline Project of the Day & 255,017 & 0.008 & 0.087 & 0.000 & 0.000 & 0.000 & 0.000 & 0.000 \\
\hline Multiple Creators & 255,017 & 0.043 & 0.203 & 0.000 & 0.000 & 0.000 & 0.000 & 0.000 \\
\hline Rewards & 255,017 & 8 & 5 & 2 & 4 & 7 & 10 & 14 \\
\hline \multicolumn{9}{|l|}{ Creator variables: } \\
\hline Bio Length & 255,017 & 103 & 107 & 14 & 39 & 76 & 119 & 227 \\
\hline Projects Backed & 255,017 & 6 & 14 & 0 & 0 & 1 & 4 & 14 \\
\hline Facebook Friends & 255,017 & 543 & 973 & 0 & 0 & 43 & 687 & 1,595 \\
\hline \multicolumn{9}{|l|}{ Macro-level variables: } \\
\hline$G D P$ & 255,017 & 55,435 & 14,945 & 41,643 & 46,242 & 55,520 & 60,357 & 67,379 \\
\hline Trust & 255,017 & 0.459 & 0.498 & 0.000 & 0.000 & 0.000 & 1.000 & 1.000 \\
\hline Internet Access & 255,017 & 0.852 & 0.049 & 0.797 & 0.819 & 0.832 & 0.909 & 0.909 \\
\hline Credit Constraints & 255,017 & 0.517 & 0.132 & 0.336 & 0.414 & 0.527 & 0.588 & 0.692 \\
\hline Funding Performance & 255,017 & 0.350 & 0.186 & 0.141 & 0.205 & 0.338 & 0.453 & 0.558 \\
\hline
\end{tabular}

This table presents the sample selection procedure and the sample composition. Panel A describes the sample selection procedure. Panels B, C, and D present the distribution of sample projects by year, category, and size, respectively. Panel E provides descriptive statistics for different measures of project success, as well as for disclosure, project, creator, and macro-level variables. All continuous variables are winsorized at the $1^{\text {st }}$ and $99^{\text {th }}$ percentile of their distributions. All variables are defined in Appendix B. 
Table 2: Disclosure and Project Success

Panel A: Probability of Success

\begin{tabular}{|c|c|c|c|c|c|c|}
\hline \multirow[b]{3}{*}{ Independent variables: } & \multicolumn{6}{|c|}{ Dependent variable: Funded } \\
\hline & Logit & OLS & Logit & OLS & Logit & OLS \\
\hline & $(1)$ & $(2)$ & (3) & (4) & $(5)$ & $(6)$ \\
\hline \multicolumn{7}{|l|}{ Disclosure variables: } \\
\hline Ln(Campaign Pitch) & $\begin{array}{l}0.234^{* * *} \\
(12.15)\end{array}$ & $\begin{array}{l}0.027 * * * \\
(9.40)\end{array}$ & & & $\begin{array}{l}0.258^{* * * *} \\
(16.14)\end{array}$ & $\begin{array}{l}0.031^{* * * *} \\
(8.34)\end{array}$ \\
\hline Ln(Risks and Challenges) & & & $\begin{array}{l}0.263^{* * *} \\
(12.70)\end{array}$ & $\begin{array}{l}0.031 * * * \\
(12.57)\end{array}$ & $\begin{array}{l}0.138^{* * * *} \\
(7.20)\end{array}$ & $\begin{array}{l}0.015^{* * * *} \\
(6.38)\end{array}$ \\
\hline \multicolumn{7}{|l|}{ Project controls: } \\
\hline $\operatorname{Ln}($ Goal $)$ & $\begin{array}{l}-0.586 \text { *** } \\
(-40.57)\end{array}$ & $\begin{array}{l}-0.079 * * * \\
(-25.06)\end{array}$ & $\begin{array}{l}-0.564 * * * \\
(-34.06)\end{array}$ & $\begin{array}{l}-0.073 * * * \\
(-23.39)\end{array}$ & $\begin{array}{l}-0.583 * * * \\
(-37.79)\end{array}$ & $\begin{array}{l}-0.074 * * * \\
(-23.44)\end{array}$ \\
\hline Ln(Duration) & $\begin{array}{l}-0.523 * * * \\
(-21.41)\end{array}$ & $\begin{array}{l}-0.086^{* * *} \\
(-20.25)\end{array}$ & $\begin{array}{l}-0.531^{* * * *} \\
(-18.20)\end{array}$ & $\begin{array}{l}-0.081 * * * \\
(-18.34)\end{array}$ & $\begin{array}{l}-0.526^{* * * *} \\
(-18.15)\end{array}$ & $\begin{array}{l}-0.081^{* * * *} \\
(-18.26)\end{array}$ \\
\hline Project of the Day & $\begin{array}{l}3.170 * * * \\
(23.08)\end{array}$ & $\begin{array}{l}0.361^{* * * *} \\
(15.79)\end{array}$ & $\begin{array}{l}3.030 * * * \\
(19.71)\end{array}$ & $\begin{array}{l}0.357 * * * \\
(17.24)\end{array}$ & $\begin{array}{l}2.980 * * * \\
(19.55)\end{array}$ & $\begin{array}{l}0.352^{* * * *} \\
(16.95)\end{array}$ \\
\hline Multiple Creators & $\begin{array}{l}0.522^{* * * *} \\
(18.76)\end{array}$ & $\begin{array}{l}0.085^{* * * *} \\
(16.21)\end{array}$ & $\begin{array}{l}0.485^{* * * *} \\
(18.46)\end{array}$ & $\begin{array}{l}0.076^{* * *} \\
(16.72)\end{array}$ & $\begin{array}{l}0.484^{* * * *} \\
(18.65)\end{array}$ & $\begin{array}{l}0.076^{* * * *} \\
(16.57)\end{array}$ \\
\hline $\operatorname{Ln}($ Rewards $)$ & $\begin{array}{l}1.035^{* * * *} \\
(38.22)\end{array}$ & $\begin{array}{l}0.133^{* * * *} \\
(28.72)\end{array}$ & $\begin{array}{l}1.107 * * * \\
(33.90)\end{array}$ & $\begin{array}{l}0.136^{* * * *} \\
(24.73)\end{array}$ & $\begin{array}{l}1.034^{* * * *} \\
(32.47)\end{array}$ & $\begin{array}{l}0.126^{* * * *} \\
(26.86)\end{array}$ \\
\hline \multicolumn{7}{|l|}{ Creator controls: } \\
\hline Ln(Bio Length) & $\begin{array}{l}0.138^{* * *} \\
(7.59)\end{array}$ & $\begin{array}{l}0.020^{* * *} \\
(8.38)\end{array}$ & $\begin{array}{l}0.138^{* * *} \\
(5.80)\end{array}$ & $\begin{array}{l}0.019 * * * \\
(6.59)\end{array}$ & $\begin{array}{l}0.128^{* * * *} \\
(5.44)\end{array}$ & $\begin{array}{l}0.018^{* * * *} \\
(6.09)\end{array}$ \\
\hline Ln(Projects Backed $)$ & $\begin{array}{l}0.714 * * * \\
(56.72)\end{array}$ & $\begin{array}{l}0.131^{* * *} \\
(58.43)\end{array}$ & $\begin{array}{l}0.719^{* * *} \\
(59.40)\end{array}$ & $\begin{array}{l}0.131^{* * *} \\
(66.71)\end{array}$ & $\begin{array}{l}0.701^{* * * *} \\
(57.91)\end{array}$ & $\begin{array}{l}0.128^{* * * *} \\
(67.95)\end{array}$ \\
\hline Ln(Facebook Friends) & $\begin{array}{l}0.012^{* * * *} \\
(4.06)\end{array}$ & $\begin{array}{l}0.002^{* * * *} \\
(4.15)\end{array}$ & $\begin{array}{l}0.018^{* * * *} \\
(5.70)\end{array}$ & $\begin{array}{l}0.003^{* * *} \\
(6.11)\end{array}$ & $\begin{array}{l}0.019 * * * \\
(6.05)\end{array}$ & $\begin{array}{l}0.003 * * * \\
(6.36)\end{array}$ \\
\hline \multicolumn{7}{|l|}{ Macro controls: } \\
\hline$G D P$ & $\begin{array}{l}0.808^{*} \\
(1.92)\end{array}$ & $\begin{array}{r}0.067 \\
(0.98)\end{array}$ & $\begin{array}{c}0.898 \\
(1.55)\end{array}$ & $\begin{array}{r}0.072 \\
(0.82)\end{array}$ & $\begin{array}{l}0.876 \\
(1.56)\end{array}$ & $\begin{array}{r}0.067 \\
(0.78)\end{array}$ \\
\hline Trust & $\begin{array}{r}0.044 \\
(1.63)\end{array}$ & $\begin{array}{l}0.009 * * \\
(2.05)\end{array}$ & $\begin{array}{l}0.016 \\
(0.51)\end{array}$ & $\begin{array}{l}0.004 \\
(1.13)\end{array}$ & $\begin{array}{c}0.018 \\
(0.58)\end{array}$ & $\begin{array}{l}0.005 \\
(1.23)\end{array}$ \\
\hline Internet Access & $\begin{array}{l}1.115^{* *} \\
(1.99)\end{array}$ & $\begin{array}{c}0.138 \\
(1.58)\end{array}$ & $\begin{array}{l}1.773^{* * * *} \\
(2.62)\end{array}$ & $\begin{array}{l}0.243^{* *} \\
(2.27)\end{array}$ & $\begin{array}{l}1.735^{* * *} \\
(2.59)\end{array}$ & $\begin{array}{l}0.236^{* *} \\
(2.21)\end{array}$ \\
\hline
\end{tabular}


Table 2: (continued)

(continued)

\begin{tabular}{|c|c|c|c|c|c|c|}
\hline \multirow[b]{3}{*}{ Independent variables: } & \multicolumn{6}{|c|}{ "Dependent variable: Funded } \\
\hline & Logit & OLS & Logit & OLS & Logit & OLS \\
\hline & $(1)$ & $(2)$ & (3) & $(4)$ & $(5)$ & $(6)$ \\
\hline \multicolumn{7}{|l|}{ Macro controls: } \\
\hline \multirow[t]{2}{*}{ Credit Constraints } & 0.433 & $0.091 *$ & 0.250 & 0.042 & 0.279 & 0.045 \\
\hline & $(1.36)$ & $(1.71)$ & $(0.60)$ & $(0.75)$ & $(0.64)$ & $(0.79)$ \\
\hline \multirow[t]{2}{*}{ Funding Performance } & $0.112 * *$ & $0.019 * *$ & 0.057 & 0.014 & 0.063 & 0.015 \\
\hline & $(2.44)$ & $(2.32)$ & $(0.94)$ & $(1.44)$ & $(1.00)$ & $(1.46)$ \\
\hline Subcategory fixed effects & Yes & No & Yes & No & Yes & No \\
\hline State fixed effects & Yes & Yes & Yes & Yes & Yes & Yes \\
\hline Year-month fixed effects & Yes & No & Yes & No & Yes & No \\
\hline Subcategory $\times$ Year-month fixed effects & No & Yes & No & Yes & No & Yes \\
\hline Obs. & 255,017 & 255,017 & 188,915 & 188,915 & 188,915 & 188,915 \\
\hline Pseudo $\mathrm{R}^{2}$ & 0.291 & & 0.305 & & 0.308 & \\
\hline Adj. $\mathrm{R}^{2}$ & & 0.353 & & 0.366 & & 0.367 \\
\hline
\end{tabular}


Table 2 (continued)

Panel B: Amount Pledged

\begin{tabular}{|c|c|c|c|}
\hline \multirow[b]{2}{*}{ Independent variables: } & \multicolumn{3}{|c|}{ Dependent variable: Ln(Pledged) } \\
\hline & (1) & $(2)$ & (3) \\
\hline \multicolumn{4}{|l|}{ Disclosure variables: } \\
\hline Ln(Campaign Pitch) & $\begin{array}{l}0.432 * * * \\
(23.20)\end{array}$ & & $\begin{array}{l}0.441^{* * *} \\
(26.03)\end{array}$ \\
\hline Ln(Risks and Challenges) & & $\begin{array}{l}0.310 * * * \\
(12.91)\end{array}$ & $\begin{array}{l}0.083^{* * *} \\
(4.87)\end{array}$ \\
\hline \multicolumn{4}{|l|}{ Project controls: } \\
\hline $\operatorname{Ln}($ Goal $)$ & $\begin{array}{l}0.043 * * \\
(2.53)\end{array}$ & $\begin{array}{l}0.066^{* * *} \\
(3.51)\end{array}$ & $\begin{array}{l}0.044 * * \\
(2.38)\end{array}$ \\
\hline Ln(Duration) & $\begin{array}{l}-0.048 \\
(-1.30)\end{array}$ & $\begin{array}{l}-0.037 \\
(-0.88)\end{array}$ & $\begin{array}{c}-0.031 \\
(-0.72)\end{array}$ \\
\hline Project of the Day & $\begin{array}{l}1.482 * * * \\
(15.49)\end{array}$ & $\begin{array}{l}1.545^{* * *} \\
(17.80)\end{array}$ & $\begin{array}{l}1.466^{* * *} \\
(17.18)\end{array}$ \\
\hline Multiple Creators & $\begin{array}{l}0.555^{* * *} \\
(16.64)\end{array}$ & $\begin{array}{l}0.543^{* * *} \\
(14.58)\end{array}$ & $\begin{array}{l}0.537^{* * *} \\
(14.98)\end{array}$ \\
\hline $\operatorname{Ln}($ Rewards $)$ & $\begin{array}{l}1.257 * * * \\
(28.94)\end{array}$ & $\begin{array}{l}1.399 * * * \\
(27.34)\end{array}$ & $\begin{array}{l}1.262^{* * * *} \\
(26.07)\end{array}$ \\
\hline \multicolumn{4}{|l|}{ Creator controls: } \\
\hline Ln(Bio Length) & $\begin{array}{l}0.057 * * * \\
(5.53)\end{array}$ & $\begin{array}{l}0.060 * * * \\
(4.33)\end{array}$ & $\begin{array}{l}0.041^{* * *} \\
(3.03)\end{array}$ \\
\hline Ln(Projects Backed $)$ & $\begin{array}{l}0.560^{* * *} \\
(33.19)\end{array}$ & $\begin{array}{l}0.585^{* * *} \\
(40.36)\end{array}$ & $\begin{array}{l}0.552^{* * *} \\
(38.85)\end{array}$ \\
\hline Ln(Facebook Friends) & $\begin{array}{l}0.019^{* * * *} \\
(4.92)\end{array}$ & $\begin{array}{l}0.021 * * * \\
(5.65)\end{array}$ & $\begin{array}{l}0.022 * * * \\
(6.04)\end{array}$ \\
\hline \multicolumn{4}{|l|}{ Macro controls: } \\
\hline$G D P$ & $\begin{array}{l}0.824 * * \\
(2.13)\end{array}$ & $\begin{array}{l}1.182 * * \\
(2.08)\end{array}$ & $\begin{array}{l}1.111^{*} \\
(2.00)\end{array}$ \\
\hline Trust & $\begin{array}{l}0.024^{*} \\
(1.78)\end{array}$ & $\begin{array}{l}-0.007 \\
(-0.53)\end{array}$ & $\begin{array}{l}-0.001 \\
(-0.05)\end{array}$ \\
\hline Internet Access & $\begin{array}{l}1.179^{* *} \\
(2.11)\end{array}$ & $\begin{array}{l}1.852^{* * * *} \\
(3.31)\end{array}$ & $\begin{array}{l}1.753^{* * *} \\
(3.13)\end{array}$ \\
\hline
\end{tabular}


Table 2 (continued)

(continued)

\begin{tabular}{|c|c|c|c|}
\hline \multirow[b]{2}{*}{ Independent variables: } & \multicolumn{3}{|c|}{ Dependent variable: Ln(Pledged) } \\
\hline & $(1)$ & $(2)$ & (3) \\
\hline \multicolumn{4}{|l|}{ Macro controls: } \\
\hline \multirow[t]{2}{*}{ Credit Constraints } & $0.629 * *$ & 0.223 & 0.267 \\
\hline & $(2.49)$ & $(0.63)$ & $(0.74)$ \\
\hline \multirow{2}{*}{ Funding Performance } & $0.134 * * *$ & $0.127^{*}$ & $0.134 * *$ \\
\hline & $(3.14)$ & $(1.99)$ & $(2.07)$ \\
\hline State fixed effects & Yes & Yes & Yes \\
\hline Subcategory $\times$ Year-month fixed effects & Yes & Yes & Yes \\
\hline Obs. & 255,017 & 188,915 & 188,915 \\
\hline Adj. $\mathrm{R}^{2}$ & 0.330 & 0.352 & 0.357 \\
\hline
\end{tabular}

This table presents the results of the analysis that examines the association between disclosure and project success. Panel A reports the coefficients from the estimation of a set of logistic (Columns (1), (3), and (5)) and OLS (Columns (2), (4), and (6)) regressions. The dependent variable is Funded, an indicator variable set equal to one if a project's funding goal is reached, and zero otherwise. Model specifications presented in Columns (1), (3), and (5) include state, subcategory, and year-month fixed effects, whereas model specifications presented in Columns (2), (4), and (6) include state and subcategory×year-month fixed effects. Panel B reports the coefficients from the estimation of a set of OLS regressions. The dependent variable is Ln(Pledged), the natural logarithm of the amount pledged to a project. All model specifications include state and subcategory $\times$ year-month fixed effects. The table reports (in parentheses) $t$-statistics and $z$-statistics based on heteroscedasticity-robust standard errors clustered by state and year-month. $* * * * *$, and $*$ denote statistical significance at the $1 \%, 5 \%$, and 10\% levels (two-tailed), respectively. All variables are defined in Appendix B. 
Table 3: The Role of Consumer Protection

Panel A: Probability of Success

\begin{tabular}{|c|c|c|c|c|}
\hline \multirow[b]{4}{*}{ Independent variables: } & \multicolumn{4}{|c|}{ Dependent variable: Funded } \\
\hline & \multicolumn{2}{|c|}{ Disclosure variable: Ln(Campaign Pitch) } & \multicolumn{2}{|c|}{ Disclosure variable: Ln(Risks and Challenges) } \\
\hline & Logit & OLS & Logit & OLS \\
\hline & $(1)$ & $(2)$ & $(3)$ & $(4)$ \\
\hline \multirow[t]{2}{*}{ Disclosure } & $0.174 * * *$ & $0.012 * * *$ & $0.248 * * *$ & $0.020 * * *$ \\
\hline & $(5.74)$ & $(3.07)$ & $(8.21)$ & $(5.15)$ \\
\hline \multirow[t]{2}{*}{ Post $\times$ Treated } & $-0.187 * * *$ & $-0.023 * * *$ & $-0.069 * * *$ & $-0.009 * * *$ \\
\hline & $(-6.82)$ & $(-7.74)$ & $(-3.15)$ & $(-3.76)$ \\
\hline \multirow[t]{2}{*}{ Disclosure $\times$ Post } & 0.020 & 0.001 & -0.002 & -0.001 \\
\hline & $(0.61)$ & $(0.52)$ & $(-0.07)$ & $(-0.30)$ \\
\hline \multirow[t]{2}{*}{ Disclosure $\times$ Treated } & $-0.006^{*}$ & 0.000 & $-0.006^{*}$ & 0.000 \\
\hline & $(-1.90)$ & $(0.21)$ & $(-1.69)$ & $(0.54)$ \\
\hline \multirow[t]{2}{*}{ Disclosure $\times$ Post $\times$ Treated } & $0.030 * * *$ & $0.004 * * *$ & $0.015^{* * *}$ & $0.002 * * *$ \\
\hline & $(6.86)$ & $(7.63)$ & $(3.23)$ & $(3.64)$ \\
\hline Project controls & Yes & Yes & Yes & Yes \\
\hline Creator controls & Yes & Yes & Yes & Yes \\
\hline Macro controls & Yes & Yes & Yes & Yes \\
\hline Subcategory fixed effects & Yes & No & Yes & No \\
\hline State fixed effects & Yes & Yes & Yes & Yes \\
\hline Year-month fixed effects & Yes & No & Yes & No \\
\hline Subcategory $\times$ Year-month fixed effects & No & Yes & No & Yes \\
\hline Obs. & 255,017 & 255,017 & 188,915 & 188,915 \\
\hline Pseudo $\mathrm{R}^{2}$ & 0.292 & & 0.305 & \\
\hline Adj. $R^{2}$ & & 0.354 & & 0.366 \\
\hline
\end{tabular}


Table 3 (continued)

Panel B: Amount Pledged

\begin{tabular}{|c|c|c|}
\hline \multirow{2}{*}{ Independent variables: } & \multicolumn{2}{|c|}{ Dependent variable: $L n($ Pledged $)$} \\
\hline & Disclosure variable: Ln(Campaign Pitch) & Disclosure variable: Ln(Risks and Challenges) \\
\hline \multirow[t]{2}{*}{ Disclosure } & $0.356^{* * *}$ & $0.230 * * *$ \\
\hline & $(9.41)$ & (4.91) \\
\hline Post $\times$ Treated & $(-6.05)$ & $(-4.30)$ \\
\hline \multirow[t]{2}{*}{ Disclosure $\times$ Post } & 0.018 & 0.015 \\
\hline & $(0.56)$ & $(0.38)$ \\
\hline Disclosure $\times$ Treated & -0.003 & -0.004 \\
\hline Disclosure $\times$ Post $\times$ Treated & $(6.16)$ & $(4.68)$ \\
\hline Project controls & Yes & Yes \\
\hline Creator controls & Yes & Yes \\
\hline Macro controls & Yes & Yes \\
\hline State fixed effects & Yes & Yes \\
\hline Subcategory $\times$ Year-month fixed effects & Yes & Yes \\
\hline Obs. & 255,017 & 188,915 \\
\hline
\end{tabular}

This table reports the results of the analysis that examines how the association between disclosure and project success changes following the introduction of Kickstarter's new terms of use. Panel A reports the coefficients from the estimation of a set of logistic (Columns (1) and (3)) and OLS (Columns (2) and (4)) regressions. The dependent variable is Funded. The model specifications presented in Columns (1) and (3) include project, creator, and macro-level control variables, as well as state, subcategory, and year-month fixed effects, whereas the model specifications presented in Columns (2) and (4) include project, creator, and macro-level control variables, as well as state and subcategory $\times$ year-month fixed effects. Post is an indicator variable set equal to one if a project's funding period starts after September 19, 2014, and zero otherwise. Treated is a measure of the strength of consumer protection in the respective project's state. Panel B reports the coefficients from the estimation of a set of OLS regressions. The dependent variable is $L n$ (Pledged). All model specifications include project, creator, and macro-level control variables, as well as state and subcategory $\times$ year-month fixed effects. The table reports (in parentheses) $t$-statistics based on heteroscedasticity-robust standard errors clustered by state and year-month. ***, $* *$, and $*$ denote statistical significance at the $1 \%, 5 \%$, and $10 \%$ levels (two-tailed), respectively. All variables are defined in Appendix B. 
Table 4: Mitigating the Influence of State-Level Time-Varying Factors

Panel A: Short Event Windows

\begin{tabular}{|c|c|c|c|c|c|c|c|c|}
\hline \multirow[b]{5}{*}{ Independent variables: } & \multicolumn{4}{|c|}{ Dependent variable: Funded } & \multicolumn{4}{|c|}{ "Dependent variable: Ln(Pledged) } \\
\hline & \multirow{2}{*}{\multicolumn{2}{|c|}{$\begin{array}{l}\text { Disclosure variable: } \\
\text { Ln(Campaign Pitch }) \\
\text { Event Window }\end{array}$}} & \multirow{2}{*}{\multicolumn{2}{|c|}{$\begin{array}{c}\text { Disclosure variable: } \\
\text { Ln(Risks and Challenges }) \\
\text { Event Window }\end{array}$}} & \multirow{2}{*}{\multicolumn{2}{|c|}{$\begin{array}{l}\text { Disclosure variable: } \\
\text { Ln(Campaign Pitch) } \\
\text { Event Window }\end{array}$}} & \multirow{2}{*}{\multicolumn{2}{|c|}{$\begin{array}{c}\text { Disclosure variable: } \\
\text { Ln(Risks and Challenges }) \\
\text { Event Window }\end{array}$}} \\
\hline & & & & & & & & \\
\hline & $(-1,+1)$ & $(-2,+2)$ & $(-1,+1)$ & $(-2,+2)$ & $(-1,+1)$ & $(-2,+2)$ & $(-1,+1)$ & $(-2,+2)$ \\
\hline & $(1)$ & $(2)$ & $(3)$ & $(4)$ & $(5)$ & (6) & $(7)$ & $(8)$ \\
\hline Disclosure & $\begin{array}{l}0.010^{* *} \\
(2.24)\end{array}$ & $\begin{array}{l}0.016^{* * *} \\
(4.56)\end{array}$ & $\begin{array}{l}\text { 0.012*** } \\
(2.85)\end{array}$ & $\begin{array}{l}0.020^{* * *} \\
(5.16)\end{array}$ & $\begin{array}{l}0.392 * * * \\
(6.60)\end{array}$ & $\begin{array}{l}0.375^{* * *} \\
(9.13)\end{array}$ & $\begin{array}{l}0.232^{* * *} \\
(3.72)\end{array}$ & $\begin{array}{l}0.230^{* * *} \\
(4.90)\end{array}$ \\
\hline Post $\times$ Treated & $\begin{array}{l}-0.013 * * * \\
(-3.89)\end{array}$ & $\begin{array}{l}-0.020 * * * \\
(-6.97)\end{array}$ & $\begin{array}{c}-0.003 \\
(-1.24)\end{array}$ & $\begin{array}{l}-0.009 * * * \\
(-3.73)\end{array}$ & $\begin{array}{l}-0.158 * * * \\
(-4.20)\end{array}$ & $\begin{array}{l}-0.147 * * * \\
(-5.81)\end{array}$ & $\begin{array}{l}-0.096^{* * *} \\
(-3.48)\end{array}$ & $\begin{array}{l}-0.095 * * * \\
(-4.29)\end{array}$ \\
\hline Disclosure $\times$ Post & $\begin{array}{c}-0.002 \\
(-0.96)\end{array}$ & $\begin{array}{r}0.001 \\
(0.28)\end{array}$ & $\begin{array}{l}-0.003 \\
(-1.09)\end{array}$ & $\begin{array}{l}-0.001 \\
(-0.30)\end{array}$ & $\begin{array}{l}-0.007 \\
(-0.32)\end{array}$ & $\begin{array}{c}0.018 \\
(0.58)\end{array}$ & $\begin{array}{l}-0.011 \\
(-0.37)\end{array}$ & $\begin{array}{r}0.015 \\
(0.38)\end{array}$ \\
\hline Disclosure $\times$ Treated & $\begin{array}{l}0.002^{* * * *} \\
(2.83)\end{array}$ & $\begin{array}{r}0.000 \\
(0.61)\end{array}$ & $\begin{array}{l}0.002^{* * * *} \\
(3.17)\end{array}$ & $\begin{array}{c}0.000 \\
(0.53)\end{array}$ & $\begin{array}{l}-0.003 \\
(-0.39)\end{array}$ & $\begin{array}{l}-0.005 \\
(-0.99)\end{array}$ & $\begin{array}{r}0.000 \\
(0.01)\end{array}$ & $\begin{array}{c}-0.004 \\
(-0.90)\end{array}$ \\
\hline Disclosure $\times$ Post $\times$ Treated & $\begin{array}{l}0.002 * * * \\
(3.85) \\
\end{array}$ & $\begin{array}{l}0.003^{* * * *} \\
(6.84) \\
\end{array}$ & $\begin{array}{r}0.001 \\
(1.18) \\
\end{array}$ & $\begin{array}{l}0.002 * * * \\
(3.61)\end{array}$ & $\begin{array}{l}0.028 * * * \\
(4.51)\end{array}$ & $\begin{array}{l}0.025^{* * *} \\
(5.99)\end{array}$ & $\begin{array}{l}0.024 * * * \\
(3.86)\end{array}$ & $\begin{array}{l}0.023 * * * \\
(4.67)\end{array}$ \\
\hline Project controls & Yes & Yes & Yes & Yes & Yes & Yes & Yes & Yes \\
\hline Creator controls & Yes & Yes & Yes & Yes & Yes & Yes & Yes & Yes \\
\hline Macro controls & Yes & Yes & Yes & Yes & Yes & Yes & Yes & Yes \\
\hline State fixed effects & Yes & Yes & Yes & Yes & Yes & Yes & Yes & Yes \\
\hline Subcategory $\times$ Year-month fixed effects & Yes & Yes & Yes & Yes & Yes & Yes & Yes & Yes \\
\hline Obs. & 97,048 & 211,146 & 96,858 & 188,876 & 97,048 & 211,146 & 96,858 & 188,876 \\
\hline Adj. $\mathrm{R}^{2}$ & 0.374 & 0.362 & 0.374 & 0.366 & 0.361 & 0.350 & 0.355 & 0.352 \\
\hline
\end{tabular}


Table 4: (continued)

Panel B: Border County Analysis

\begin{tabular}{|c|c|c|c|c|c|c|c|c|}
\hline \multirow[b]{3}{*}{ Independent variables: } & \multicolumn{4}{|c|}{ Dependent variable: Funded } & \multicolumn{4}{|c|}{ "Dependent variable: Ln(Pledged) } \\
\hline & \multicolumn{2}{|c|}{$\begin{array}{l}\text { Disclosure variable: } \\
\text { Ln(Campaign Pitch) }\end{array}$} & \multicolumn{2}{|c|}{$\begin{array}{c}\text { Disclosure variable: } \\
\text { Ln(Risks and Challenges) }\end{array}$} & \multicolumn{2}{|c|}{$\begin{array}{l}\text { Disclosure variable: } \\
\text { Ln(Campaign Pitch) }\end{array}$} & \multicolumn{2}{|c|}{$\begin{array}{c}\text { Disclosure variable: } \\
\text { Ln(Risks and Challenges) }\end{array}$} \\
\hline & $(1)$ & $(2)$ & $(3)$ & $(4)$ & $(5)$ & $(6)$ & $(7)$ & $(8)$ \\
\hline Disclosure & $\begin{array}{l}0.013^{* * * *} \\
(3.13)\end{array}$ & $\begin{array}{l}0.021 * * \\
(2.34)\end{array}$ & $\begin{array}{l}0.021 * * * \\
(5.87)\end{array}$ & $\begin{array}{l}0.019 * * \\
(2.08)\end{array}$ & $\begin{array}{l}0.361^{* * *} \\
(10.06)\end{array}$ & $\begin{array}{l}0.404 * * * \\
(8.76)\end{array}$ & $\begin{array}{l}0.240 * * * \\
(5.06)\end{array}$ & $\begin{array}{l}0.224 * * * \\
(4.11)\end{array}$ \\
\hline Post $\times$ Treated & $\begin{array}{l}-0.024 * * * \\
(-7.54)\end{array}$ & $\begin{array}{l}-0.027 * * * \\
(-6.39)\end{array}$ & $\begin{array}{l}-0.008 * * * \\
(-2.86)\end{array}$ & $\begin{array}{l}-0.008^{* *} \\
(-2.39)\end{array}$ & $\begin{array}{l}-0.139 * * * \\
(-5.55)\end{array}$ & $\begin{array}{l}-0.154 * * * \\
(-5.48)\end{array}$ & $\begin{array}{l}-0.085 * * * \\
(-3.52)\end{array}$ & $\begin{array}{l}-0.102 * * * \\
(-3.87)\end{array}$ \\
\hline Disclosure $\times$ Post & $\begin{array}{c}0.003 \\
(0.92)\end{array}$ & $\begin{array}{l}0.004 \\
(1.13)\end{array}$ & $\begin{array}{r}0.000 \\
(0.09)\end{array}$ & $\begin{array}{r}0.001 \\
(0.22)\end{array}$ & $\begin{array}{r}0.019 \\
(0.55)\end{array}$ & $\begin{array}{c}0.008 \\
(0.29)\end{array}$ & $\begin{array}{r}0.013 \\
(0.34)\end{array}$ & $\begin{array}{l}-0.005 \\
(-0.19)\end{array}$ \\
\hline Disclosure $\times$ Treated & $\begin{array}{l}-0.000 \\
(-0.37)\end{array}$ & $\begin{array}{l}-0.001^{*} \\
(-1.68)\end{array}$ & $\begin{array}{r}0.000 \\
(0.50)\end{array}$ & $\begin{array}{l}-0.000 \\
(-0.14)\end{array}$ & $\begin{array}{l}-0.003 \\
(-0.80)\end{array}$ & $\begin{array}{l}-0.008 \\
(-1.55)\end{array}$ & $\begin{array}{l}-0.003 \\
(-0.76)\end{array}$ & $\begin{array}{c}-0.004 \\
(-0.73)\end{array}$ \\
\hline Disclosure $\times$ Post $\times$ Treated & $\begin{array}{l}0.004^{* * * *} \\
(7.34)\end{array}$ & $\begin{array}{l}0.004^{* * *} \\
(5.39)\end{array}$ & $\begin{array}{l}0.002 * * * \\
(2.79)\end{array}$ & $\begin{array}{l}0.002^{* *} \\
(2.38)\end{array}$ & $\begin{array}{l}0.024 * * * \\
(5.69)\end{array}$ & $\begin{array}{l}0.026^{* * *} \\
(5.62)\end{array}$ & $\begin{array}{l}0.020^{* * * *} \\
(3.88)\end{array}$ & $\begin{array}{l}0.025^{* * *} \\
(4.76)\end{array}$ \\
\hline Project controls & Yes & Yes & Yes & Yes & Yes & Yes & Yes & Yes \\
\hline Creator controls & Yes & Yes & Yes & Yes & Yes & Yes & Yes & Yes \\
\hline Macro controls & Yes & Yes & Yes & Yes & Yes & Yes & Yes & Yes \\
\hline Subcategory fixed effects & Yes & Yes & Yes & Yes & Yes & Yes & Yes & Yes \\
\hline County fixed effects & Yes & Yes & Yes & Yes & Yes & Yes & Yes & Yes \\
\hline Year-month fixed effects & Yes & No & Yes & No & Yes & No & Yes & No \\
\hline Border $\times$ Year-month fixed effects & No & Yes & No & Yes & No & Yes & No & Yes \\
\hline Obs. & 254,792 & 87,454 & 188,744 & 63,293 & 254,792 & 87,454 & 188,744 & 63,293 \\
\hline Adj. $R^{2}$ & 0.337 & 0.398 & 0.349 & 0.408 & 0.315 & 0.371 & 0.337 & 0.388 \\
\hline
\end{tabular}


Table 4: (continued)

Panel C: Fixed Effects Analysis

\begin{tabular}{|c|c|c|c|c|c|c|c|c|c|c|c|c|}
\hline \multirow[b]{3}{*}{ Independent variables: } & \multicolumn{6}{|c|}{ Dependent variable: Funded } & \multicolumn{6}{|c|}{ Dependent variable: $L n($ Pledged $)$} \\
\hline & \multicolumn{3}{|c|}{$\begin{array}{l}\text { Disclosure variable: } \\
\text { Ln(Campaign Pitch) }\end{array}$} & \multicolumn{3}{|c|}{$\begin{array}{c}\text { Disclosure variable: } \\
\text { Ln(Risks and Challenges) }\end{array}$} & \multicolumn{3}{|c|}{$\begin{array}{l}\text { Disclosure variable: } \\
\text { Ln(Campaign Pitch) }\end{array}$} & \multicolumn{3}{|c|}{$\begin{array}{c}\text { Disclosure variable: } \\
\text { Ln(Risks and Challenges) }\end{array}$} \\
\hline & $(1)$ & (2) & (3) & (4) & $(5)$ & (6) & (7) & $(8)$ & (9) & $(10)$ & (11) & (12) \\
\hline Disclosure & $\begin{array}{c}0.009 \\
(1.43)\end{array}$ & $\begin{array}{c}0.008 \\
(1.40)\end{array}$ & $\begin{array}{c}0.009 \\
(1.22)\end{array}$ & $\begin{array}{l}0.018^{* * *} \\
(3.37)\end{array}$ & $\begin{array}{l}0.017 * * * \\
(2.97)\end{array}$ & $\begin{array}{l}0.024 * * * \\
(3.40)\end{array}$ & $\begin{array}{l}0.322 * * * \\
(5.84)\end{array}$ & $\begin{array}{l}0.306^{* * *} \\
(5.47)\end{array}$ & $\begin{array}{l}0.276^{* * *} \\
(5.31)\end{array}$ & $\begin{array}{l}0.187 * * \\
(2.42)\end{array}$ & $\begin{array}{l}0.162^{* *} \\
(2.08)\end{array}$ & $\begin{array}{l}0.192^{* * *} \\
(2.81)\end{array}$ \\
\hline Disclosure $\times$ Post & $\begin{array}{r}0.011 \\
(1.23)\end{array}$ & $\begin{array}{r}0.009 \\
(1.14)\end{array}$ & $\begin{array}{r}0.001 \\
(0.08)\end{array}$ & $\begin{array}{c}0.004 \\
(0.58)\end{array}$ & $\begin{array}{c}0.004 \\
(0.56)\end{array}$ & $\begin{array}{c}-0.004 \\
(-0.45)\end{array}$ & $\begin{array}{r}0.122 \\
(1.42)\end{array}$ & $\begin{array}{c}0.123 \\
(1.45)\end{array}$ & $\begin{array}{c}0.114 \\
(1.42)\end{array}$ & $\begin{array}{r}0.121 \\
(1.20)\end{array}$ & $\begin{array}{r}0.134 \\
(1.28)\end{array}$ & $\begin{array}{r}0.141 \\
(1.39)\end{array}$ \\
\hline Disclosure $\times$ Treated & $\begin{array}{r}0.000 \\
(0.61)\end{array}$ & $\begin{array}{r}0.001 \\
(0.85)\end{array}$ & $\begin{array}{r}0.001 \\
(0.94)\end{array}$ & $\begin{array}{r}0.001 \\
(1.09)\end{array}$ & $\begin{array}{r}0.001 \\
(0.95)\end{array}$ & $\begin{array}{r}-0.000 \\
(-0.23)\end{array}$ & $\begin{array}{r}0.002 \\
(0.32)\end{array}$ & $\begin{array}{r}0.002 \\
(0.41)\end{array}$ & $\begin{array}{r}0.006 \\
(1.19)\end{array}$ & $\begin{array}{r}0.003 \\
(0.49)\end{array}$ & $\begin{array}{r}0.003 \\
(0.42)\end{array}$ & $\begin{array}{l}-0.002 \\
(-0.34)\end{array}$ \\
\hline Disclosure $\times$ Post $\times$ Treated & $\begin{array}{l}0.003 * * * \\
(3.31)\end{array}$ & $\begin{array}{l}0.003^{* * *} \\
(3.81)\end{array}$ & $\begin{array}{l}0.004^{* * *} \\
(5.21)\end{array}$ & $\begin{array}{l}0.001^{*} \\
(1.81)\end{array}$ & $\begin{array}{l}0.001^{* *} \\
(2.02)\end{array}$ & $\begin{array}{l}0.003 * * * \\
(2.92)\end{array}$ & $\begin{array}{l}0.014^{*} \\
(1.80)\end{array}$ & $\begin{array}{l}0.014^{*} \\
(1.92)\end{array}$ & $\begin{array}{l}0.016^{* *} \\
(2.19)\end{array}$ & $\begin{array}{c}0.010 \\
(1.19)\end{array}$ & $\begin{array}{c}0.012 \\
(1.36)\end{array}$ & $\begin{array}{l}0.015^{*} \\
(1.73)\end{array}$ \\
\hline Project controls & Yes & Yes & Yes & Yes & Yes & Yes & Yes & Yes & Yes & Yes & Yes & Yes \\
\hline Creator controls & Yes & Yes & Yes & Yes & Yes & Yes & Yes & Yes & Yes & Yes & Yes & Yes \\
\hline Subcategory fixed effects & Yes & No & No & Yes & No & No & Yes & No & No & Yes & No & No \\
\hline Subcategory $\times$ Year-month fixed effects & No & Yes & No & No & Yes & No & No & Yes & No & No & Yes & No \\
\hline State $\times$ Year-month fixed effects & Yes & Yes & No & Yes & Yes & No & Yes & Yes & No & Yes & Yes & No \\
\hline Subcategory $\times$ State $\times$ Year-month fixed effects & No & No & Yes & No & No & Yes & No & No & Yes & No & No & Yes \\
\hline Obs. & 255,017 & 255,017 & 255,017 & 188,915 & 188,915 & 188,915 & 255,017 & 255,017 & 255,017 & 188,915 & 188,915 & 188,915 \\
\hline Adj. $R^{2}$ & 0.335 & 0.367 & 0.607 & 0.343 & 0.376 & 0.628 & 0.315 & 0.345 & 0.614 & 0.332 & 0.364 & 0.641 \\
\hline
\end{tabular}

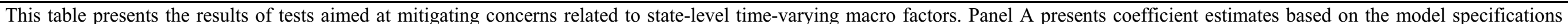

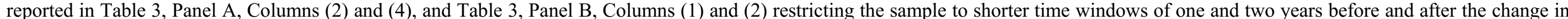

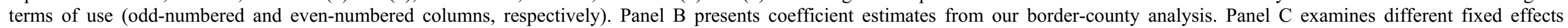

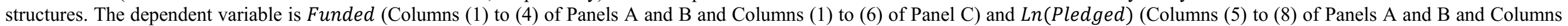

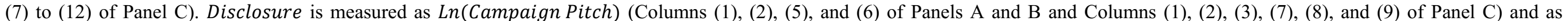

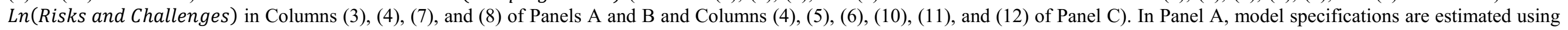

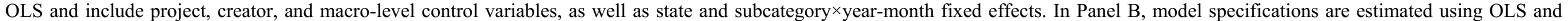

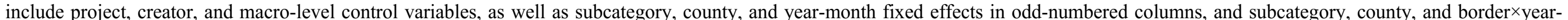

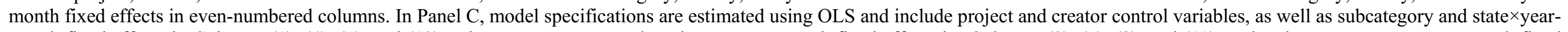

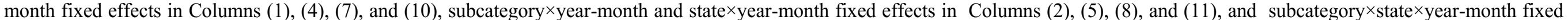

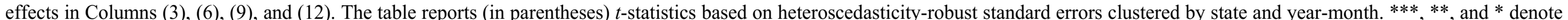
statistical significance at the $1 \%, 5 \%$, and $10 \%$ levels (two-tailed), respectively. All variables are defined in Appendix B. 
Table 5: Consumer Protection and Project Backers

Panel A: Number of Backers

\begin{tabular}{|c|c|c|}
\hline \multirow[b]{3}{*}{ Independent variables: } & \multicolumn{2}{|c|}{ Dependent variable: Ln(Backers) } \\
\hline & Disclosure variable: Ln(Campaign Pitch) & Disclosure variable: Ln(Risks and Challenges) \\
\hline & $(1)$ & $(2)$ \\
\hline \multirow[t]{2}{*}{ Disclosure } & $0.221 * * *$ & $0.127 * * *$ \\
\hline & $(9.04)$ & $(4.51)$ \\
\hline \multirow[t]{2}{*}{ Post $\times$ Treated } & $-0.088 * * *$ & $-0.052 * * *$ \\
\hline & $(-7.30)$ & $(-4.50)$ \\
\hline \multirow[t]{2}{*}{ Disclosure $\times$ Post } & 0.011 & 0.009 \\
\hline & $(0.79)$ & $(0.55)$ \\
\hline \multirow[t]{2}{*}{ Disclosure $\times$ Treated } & 0.003 & 0.003 \\
\hline & $(1.29)$ & $(1.02)$ \\
\hline \multirow[t]{2}{*}{ Disclosure $\times$ Post $\times$ Treated } & $0.015^{* * *}$ & $0.012 * * *$ \\
\hline & $(7.57)$ & $(4.73)$ \\
\hline Project controls & Yes & Yes \\
\hline Creator controls & Yes & Yes \\
\hline Macro controls & Yes & Yes \\
\hline State fixed effects & Yes & Yes \\
\hline Subcategory $\times$ Year-month fixed effects & Yes & Yes \\
\hline Obs. & 255,017 & 188,915 \\
\hline Adj. $\mathrm{R}^{2}$ & 0.511 & 0.537 \\
\hline
\end{tabular}


Table 5 (continued)

Panel B: Type of Backers

\begin{tabular}{|c|c|c|c|c|}
\hline \multirow[b]{3}{*}{ Independent variables: } & \multicolumn{2}{|c|}{ "Dependent variable: Ln(New Backers) } & \multicolumn{2}{|c|}{ "Dependent variable: Ln(Returning Backers) } \\
\hline & $\begin{array}{c}\text { Disclosure variable: } \\
\text { Ln(Campaign Pitch })\end{array}$ & $\begin{array}{c}\text { Disclosure variable: } \\
\text { Ln(Risks and Challenges) }\end{array}$ & $\begin{array}{c}\text { Disclosure variable: } \\
\text { Ln(Campaign Pitch) }\end{array}$ & $\begin{array}{c}\text { Disclosure variable: } \\
\text { Ln(Risks and Challenges) }\end{array}$ \\
\hline & $(1)$ & $(2)$ & $(3)$ & $(4)$ \\
\hline Disclosure & $\begin{array}{l}0.155^{* * *} \\
(5.79)\end{array}$ & $\begin{array}{l}0.096^{* * *} \\
(3.46)\end{array}$ & $\begin{array}{l}0.176^{* * *} \\
(5.83)\end{array}$ & $\begin{array}{l}0.084 * * \\
(2.45)\end{array}$ \\
\hline Post $\times$ Treated & $\begin{array}{l}-0.052 * * * \\
(-5.53)\end{array}$ & $\begin{array}{l}-0.039 * * * \\
(-4.37)\end{array}$ & $\begin{array}{l}-0.097 * * * \\
(-7.07)\end{array}$ & $\begin{array}{l}-0.046^{* * *} \\
(-4.93)\end{array}$ \\
\hline Disclosure $\times$ Post & $\begin{array}{c}0.008 \\
(1.26)\end{array}$ & $\begin{array}{r}0.009 \\
(0.70)\end{array}$ & $\begin{array}{r}0.013 \\
(0.90)\end{array}$ & $\begin{array}{r}0.010 \\
(0.69)\end{array}$ \\
\hline Disclosure $\times$ Treated & $\begin{array}{l}0.008^{* * * *} \\
(2.96)\end{array}$ & $\begin{array}{l}0.007^{* *} \\
(2.45)\end{array}$ & $\begin{array}{l}0.006^{*} \\
(1.78)\end{array}$ & $\begin{array}{l}0.007^{*} \\
(1.75)\end{array}$ \\
\hline Disclosure $\times$ Post $\times$ Treated & $\begin{array}{l}0.008^{* * * *} \\
(5.49)\end{array}$ & $\begin{array}{l}0.009^{* * * *} \\
(4.13)\end{array}$ & $\begin{array}{l}0.016^{* * *} \\
(7.15)\end{array}$ & $\begin{array}{l}0.010^{* * * *} \\
(4.81)\end{array}$ \\
\hline Project controls & Yes & Yes & Yes & Yes \\
\hline Creator controls & Yes & Yes & Yes & Yes \\
\hline Macro controls & Yes & Yes & Yes & Yes \\
\hline State fixed effects & Yes & Yes & Yes & Yes \\
\hline Subcategory $\times$ Year-month fixed effects & Yes & Yes & Yes & Yes \\
\hline Obs. & 255,017 & 188,915 & 255,017 & 188,915 \\
\hline Adj. $\mathrm{R}^{2}$ & 0.408 & 0.427 & 0.518 & 0.534 \\
\hline
\end{tabular}


Table 5 (continued)

Panel C: Backer Engagement

\begin{tabular}{|c|c|c|c|c|}
\hline \multirow[b]{3}{*}{ Independent variables: } & \multicolumn{2}{|c|}{ Dependent variable: Ln(Backer Comments) } & \multicolumn{2}{|c|}{ "Dependent variable: Ln(Superbacker Comments) } \\
\hline & $\begin{array}{l}\text { Disclosure variable: } \\
\text { Ln(Campaign Pitch) }\end{array}$ & $\begin{array}{c}\text { Disclosure variable: } \\
\text { Ln(Risks and Challenges) }\end{array}$ & $\begin{array}{l}\text { Disclosure variable: } \\
\text { Ln(Campaign Pitch) }\end{array}$ & $\begin{array}{c}\text { Disclosure variable: } \\
\text { Ln(Risks and Challenges })\end{array}$ \\
\hline & $(1)$ & $(2)$ & $(3)$ & $(4)$ \\
\hline Disclosure & $\begin{array}{l}0.189 * * * \\
(6.73)\end{array}$ & $\begin{array}{l}0.067 * * \\
(2.55)\end{array}$ & $\begin{array}{l}0.105^{* * * *} \\
(5.39)\end{array}$ & $\begin{array}{l}0.064 * * * \\
(3.29)\end{array}$ \\
\hline Post $\times$ Treated & $\begin{array}{l}-0.030^{* *} \\
(-2.22)\end{array}$ & $\begin{array}{l}-0.027^{* *} \\
(-2.33)\end{array}$ & $\begin{array}{l}-0.074 * * * \\
(-5.28)\end{array}$ & $\begin{array}{l}-0.031^{* * *} \\
(-4.22)\end{array}$ \\
\hline Disclosure $\times$ Post & $\begin{array}{l}0.027 * * * \\
(2.82)\end{array}$ & $\begin{array}{l}0.041^{* * *} \\
(2.74)\end{array}$ & $\begin{array}{c}0.019 \\
(1.35)\end{array}$ & $\begin{array}{l}0.014^{*} \\
(1.77)\end{array}$ \\
\hline Disclosure $\times$ Treated & $\begin{array}{l}0.009^{* * *} \\
(3.05)\end{array}$ & $\begin{array}{l}0.008^{* *} \\
(2.63)\end{array}$ & $\begin{array}{l}-0.004^{*} \\
(-1.87)\end{array}$ & $\begin{array}{r}-0.002 \\
(-1.08)\end{array}$ \\
\hline Disclosure $\times$ Post $\times$ Treated & $\begin{array}{l}0.005^{*} \\
(1.98)\end{array}$ & $\begin{array}{l}0.006^{*} \\
(1.97)\end{array}$ & $\begin{array}{l}0.012^{* * * *} \\
(5.15)\end{array}$ & $\begin{array}{l}0.007^{* * * *} \\
(3.62)\end{array}$ \\
\hline Project controls & Yes & Yes & Yes & Yes \\
\hline Creator controls & Yes & Yes & Yes & Yes \\
\hline Macro controls & Yes & Yes & Yes & Yes \\
\hline State fixed effects & Yes & Yes & Yes & Yes \\
\hline Subcategory $\times$ Year-month fixed effects & Yes & Yes & Yes & Yes \\
\hline Obs. & 255,017 & 188,915 & 255,017 & 188,915 \\
\hline Adj. $R^{2}$ & 0.351 & 0.378 & 0.374 & 0.385 \\
\hline
\end{tabular}

This table presents the result of the analysis that examines how the association between project disclosure and (i) number of backers (Panel A), (ii) type of backers (Panel B), and (iii) backer engagement (Panel C) changes following the introduction of Kickstarter's new terms of use. The dependent variable is Ln(Backers) in Panel A, Ln(New Backers) and Ln(Returning Backers) in Panel B, and Ln(Backer Comments) and Ln(Superbacker Comments) in Panel C. In all panels, Disclosure is measured as Ln(Campaign Pitch) in odd-numbered columns and Ln(Risks and Challenges) in even-numbered columns. All model specifications are estimated using OLS and include project, creator, and macro-level control variables, as well as state and subcategory×year-month fixed effects. The table reports (in parentheses) $t$-statistics based on heteroscedasticity-robust standard errors clustered by state and year-month. ***, **, and * denote statistical significance at the $1 \%$, $5 \%$, and $10 \%$ levels (two-tailed), respectively. All variables are defined in Appendix B. 


\section{Table 6: Cross-Sectional Analysis}

Panel A: Reward Magnitude

\begin{tabular}{|c|c|c|c|c|c|c|c|c|}
\hline \multirow[b]{5}{*}{ Independent variables: } & \multicolumn{4}{|c|}{ Dependent variable: Funded } & \multicolumn{4}{|c|}{ "Dependent variable: Ln(Pledged) } \\
\hline & \multirow{2}{*}{\multicolumn{2}{|c|}{$\begin{array}{l}\text { Disclosure variable: } \\
\text { Ln(Campaign Pitch) } \\
\text { Reward Magnitude }\end{array}$}} & \multirow{2}{*}{\multicolumn{2}{|c|}{$\begin{array}{c}\text { Disclosure variable: } \\
\text { Ln(Risks and Challenges) } \\
\text { Reward Magnitude }\end{array}$}} & \multirow{2}{*}{\multicolumn{2}{|c|}{$\begin{array}{c}\text { Disclosure variable: } \\
\text { Ln(Campaign Pitch) } \\
\text { Reward Magnitude }\end{array}$}} & \multirow{2}{*}{\multicolumn{2}{|c|}{$\begin{array}{c}\text { Disclosure variable: } \\
\text { Ln(Risks and Challenges) } \\
\text { Reward Magnitude }\end{array}$}} \\
\hline & & & & & & & & \\
\hline & Low & High & Low & High & Low & High & Low & High \\
\hline & $(1)$ & $(2)$ & (3) & (4) & $(5)$ & $(6)$ & $(7)$ & $(8)$ \\
\hline Disclosure & $\begin{array}{l}0.013 * * \\
(2.64)\end{array}$ & $\begin{array}{l}0.015 * * * \\
(2.77)\end{array}$ & $\begin{array}{l}0.031 * * * \\
(5.73)\end{array}$ & $\begin{array}{c}0.013 * \\
(1.96)\end{array}$ & $\begin{array}{l}0.365^{* * *} \\
(7.57)\end{array}$ & $\begin{array}{l}0.390 * * * \\
(9.36)\end{array}$ & $\begin{array}{l}0.279 * * * \\
(5.18)\end{array}$ & $\begin{array}{l}0.254 * * * \\
(4.52)\end{array}$ \\
\hline Post $\times$ Treated & $\begin{array}{l}-0.016^{* * *} \\
(-4.84)\end{array}$ & $\begin{array}{l}-0.024 * * * \\
(-8.30)\end{array}$ & $\begin{array}{l}-0.004 * * \\
(-2.34)\end{array}$ & $\begin{array}{l}-0.009 * * * \\
(-3.28)\end{array}$ & $\begin{array}{l}-0.110^{* * *} \\
(-4.73)\end{array}$ & $\begin{array}{l}-0.166^{* * * *} \\
(-5.59)\end{array}$ & $\begin{array}{l}-0.060 * * * \\
(-2.85)\end{array}$ & $\begin{array}{l}-0.121 * * * \\
(-5.33)\end{array}$ \\
\hline Disclosure $\times$ Post & $\begin{array}{c}0.002 \\
(0.70)\end{array}$ & $\begin{array}{c}-0.000 \\
(-0.05)\end{array}$ & $\begin{array}{c}-0.002 \\
(-0.91)\end{array}$ & $\begin{array}{l}-0.001 \\
(-0.32)\end{array}$ & $\begin{array}{c}0.024 \\
(0.85)\end{array}$ & $\begin{array}{c}0.008 \\
(0.20)\end{array}$ & $\begin{array}{c}0.016 \\
(0.49)\end{array}$ & $\begin{array}{c}0.001 \\
(0.02)\end{array}$ \\
\hline Disclosure $\times$ Treated & $\begin{array}{c}0.000 \\
(0.52)\end{array}$ & $\begin{array}{r}0.000 \\
(0.12)\end{array}$ & $\begin{array}{c}0.000 \\
(0.84)\end{array}$ & $\begin{array}{c}0.000 \\
(0.23)\end{array}$ & $\begin{array}{c}-0.004 \\
(-0.64)\end{array}$ & $\begin{array}{l}-0.007 * \\
(-1.80)\end{array}$ & $\begin{array}{l}-0.002 \\
(-0.32)\end{array}$ & $\begin{array}{l}-0.013 * * * \\
(-2.74)\end{array}$ \\
\hline Disclosure $\times$ Post $\times$ Treated & $\begin{array}{l}0.002^{* * * *} \\
(4.33)\end{array}$ & $\begin{array}{l}0.004^{* * * *} \\
(8.21)\end{array}$ & $\begin{array}{l}0.001 * * \\
(2.13)\end{array}$ & $\begin{array}{l}0.002 * * * \\
(3.22)\end{array}$ & $\begin{array}{l}0.020^{* * *} \\
(4.85)\end{array}$ & $\begin{array}{l}0.028 * * * \\
(5.97)\end{array}$ & $\begin{array}{l}0.015^{* * * *} \\
(3.26)\end{array}$ & $\begin{array}{l}0.028^{* * *} \\
(5.60)\end{array}$ \\
\hline Project controls & Yes & Yes & Yes & Yes & Yes & Yes & Yes & Yes \\
\hline Creator controls & Yes & Yes & Yes & Yes & Yes & Yes & Yes & Yes \\
\hline Subcategory $\times$ Year-month fixed effects & Yes & Yes & Yes & Yes & Yes & Yes & Yes & Yes \\
\hline $\begin{array}{l}\text { Test for difference in Disclosure } \times \text { Post } \times \text { Treated } \\
\chi^{2} \text {-test } \mathrm{p} \text {-value: } \text { Low }=\text { High }\end{array}$ & & 271 & & & 0.02 & & & \\
\hline Obs. & 133,197 & 121,687 & 104,096 & 84,754 & 133,197 & 121,687 & 104,096 & 84,754 \\
\hline Adj. $R^{2}$ & 0.390 & 0.356 & 0.402 & 0.365 & 0.308 & 0.344 & 0.325 & 0.370 \\
\hline
\end{tabular}


Table 6 (continued)

Panel B: Confidence in Courts

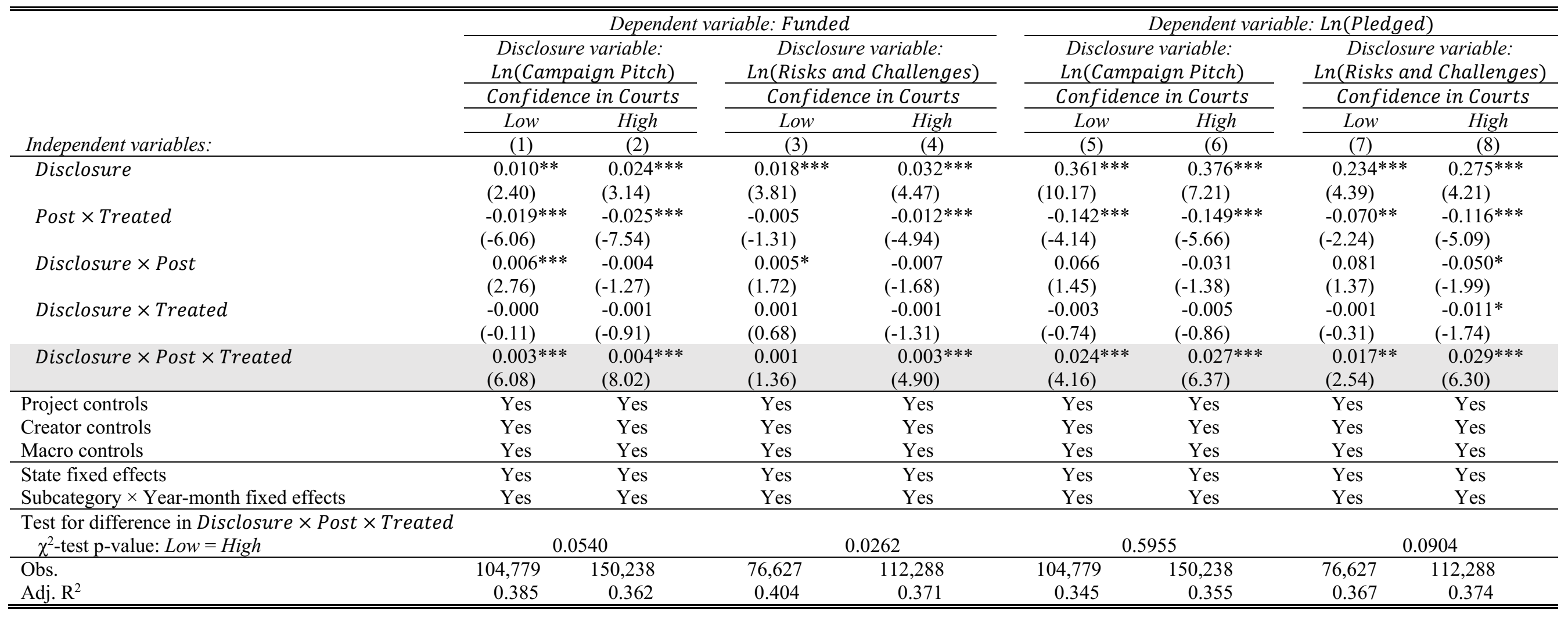


Table 6 (continued)

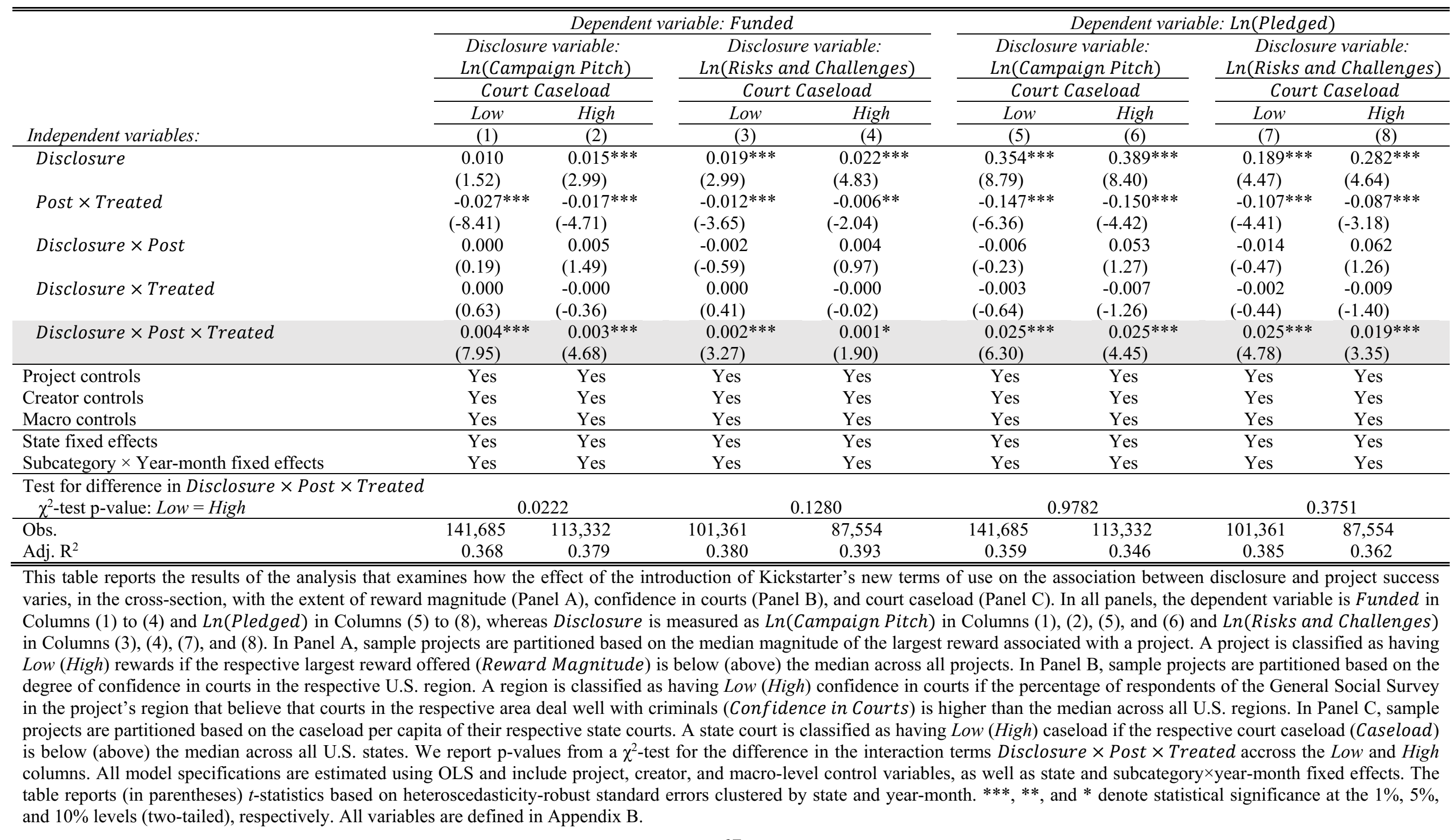


Table 7: Disclosure and Project Quality

\begin{tabular}{|c|c|c|}
\hline \multirow[b]{3}{*}{ Independent variables: } & \multicolumn{2}{|c|}{ Dependent variable: Suspected Fraud } \\
\hline & $\begin{array}{l}\text { Disclosure variable: } \\
\text { Ln(Campaign Pitch) }\end{array}$ & $\begin{array}{c}\text { Disclosure variable: } \\
\text { Ln(Risks and Challenges) }\end{array}$ \\
\hline & $(1)$ & $(2)$ \\
\hline \multirow[t]{2}{*}{ Disclosure } & 0.051 & 0.036 \\
\hline & $(1.30)$ & $(0.81)$ \\
\hline \multirow[t]{2}{*}{ Post $\times$ Treated } & $0.038 * * *$ & $0.035 * * *$ \\
\hline & $(3.56)$ & $(2.71)$ \\
\hline \multirow[t]{2}{*}{ Disclosure $\times$ Post } & -0.009 & 0.023 \\
\hline & $(-0.53)$ & $(1.31)$ \\
\hline \multirow[t]{2}{*}{ Disclosure $\times$ Treated } & 0.000 & -0.001 \\
\hline & $(0.02)$ & $(-0.25)$ \\
\hline \multirow{2}{*}{ Disclosure $\times$ Post $\times$ Treated } & $-0.006 * * *$ & $-0.008 * * *$ \\
\hline & $(-3.14)$ & $(-3.53)$ \\
\hline Project controls & Yes & Yes \\
\hline Creator controls & Yes & Yes \\
\hline Macro controls & Yes & Yes \\
\hline State fixed effects & Yes & Yes \\
\hline Subcategory $\times$ Year-month fixed effects & Yes & Yes \\
\hline Obs. & 50,882 & 33,537 \\
\hline Adj. $R^{2}$ & 0.187 & 0.216 \\
\hline
\end{tabular}

This table reports the results of the analysis that examines how the association between disclosure and project quality changes following the introduction of Kickstarter's new terms of use. The dependent variable is Suspected Fraud, the number of fraud allegations made by backers of a successfully-funded project in the comments tab scaled by number of backers. Fraud allegations are identified using the fraud word list presented in Appendix C. Disclosure is Ln(Campaign Pitch) in Column (1) and Ln(Risks and Challenges) in Column (2). All model specifications are estimated using OLS and include project, creator, and macro-level control variables, as well as state and subcategory $\times$ year-month fixed effects. The table reports (in parentheses) $t$ statistics based on heteroscedasticity-robust standard errors clustered by state and year-month. ***, **, and * denote statistical significance at the $1 \%, 5 \%$, and $10 \%$ levels (two-tailed), respectively. All variables are defined in Appendix B. 
Table 8: Disclosure Attributes

Panel A: Campaign Pitch

\begin{tabular}{|c|c|c|c|c|c|c|}
\hline \multirow[b]{3}{*}{ Independent variables: } & \multicolumn{6}{|c|}{ Dependent variable: Disclosure Attribute } \\
\hline & Length & Readability & Sentiment & Lexical Diversity & Legalese & Quantitative Information \\
\hline & (1) & (2) & (3) & (4) & $(5)$ & (6) \\
\hline Post $\times$ Treated & $\begin{array}{l}0.003^{* * *} \\
(3.79)\end{array}$ & $\begin{array}{l}0.009^{* * *} \\
(3.75)\end{array}$ & $\begin{array}{r}0.000 \\
(1.66) \\
\end{array}$ & $\begin{array}{l}0.005^{* * *} \\
(3.04)\end{array}$ & $\begin{array}{l}0.001 * * \\
(2.27)\end{array}$ & $\begin{array}{l}0.002^{*} \\
(1.98)\end{array}$ \\
\hline Project controls & Yes & Yes & Yes & Yes & Yes & Yes \\
\hline Creator controls & Yes & Yes & Yes & Yes & Yes & Yes \\
\hline Macro controls & Yes & Yes & Yes & Yes & Yes & Yes \\
\hline State fixed effects & Yes & Yes & Yes & Yes & Yes & Yes \\
\hline Subcategory $\times$ Year-month fixed effects & Yes & Yes & Yes & Yes & Yes & Yes \\
\hline Obs. & 255,017 & 255,017 & 255,017 & 255,017 & 255,017 & 255,017 \\
\hline Adj. $R^{2}$ & 0.387 & 0.127 & 0.116 & 0.390 & 0.105 & 0.301 \\
\hline
\end{tabular}

Panel B: Risks and Challenges

\begin{tabular}{|c|c|c|c|c|c|c|}
\hline \multirow[b]{3}{*}{ Independent variables: } & \multicolumn{6}{|c|}{ Dependent variable: Disclosure Attribute } \\
\hline & Length & Readability & Sentiment & Lexical Diversity & Legalese & Quantitative Information \\
\hline & $(1)$ & $(2)$ & (3) & $(4)$ & $(5)$ & $(6)$ \\
\hline Post $\times$ Treated & $\begin{array}{l}0.002 * * * \\
(2.84)\end{array}$ & $\begin{array}{c}-0.002 \\
(-0.70)\end{array}$ & $\begin{array}{r}0.000 \\
(1.13) \\
\end{array}$ & $\begin{array}{l}0.003^{* *} \\
(2.54)\end{array}$ & $\begin{array}{r}-0.000 \\
(-0.13)\end{array}$ & $\begin{array}{l}0.001^{* *} \\
(2.34)\end{array}$ \\
\hline Project controls & Yes & Yes & Yes & Yes & Yes & Yes \\
\hline Creator controls & Yes & Yes & Yes & Yes & Yes & Yes \\
\hline Macro controls & Yes & Yes & Yes & Yes & Yes & Yes \\
\hline State fixed effects & Yes & Yes & Yes & Yes & Yes & Yes \\
\hline Subcategory $\times$ Year-month fixed effects & Yes & Yes & Yes & Yes & Yes & Yes \\
\hline Obs. & 188,915 & 188,915 & 188,915 & 188,915 & 188,915 & 188,915 \\
\hline Adj. $R^{2}$ & 0.239 & 0.086 & 0.068 & 0.235 & 0.061 & 0.127 \\
\hline
\end{tabular}

This table reports the results of the analysis that examines changes in disclosure attributes following the introduction of Kickstarter's new terms of use. The results presented in Panel A (Panel B) pertain to disclosure attributes of a project's campaign pitch (risks and challenges section). The dependent variable is the individual Disclosure Attribute (i.e., length, readability, sentiment, lexical diversity, legalese, or quantitative information). In Column (1) of Panel A (Panel B), Length is measured as Ln (Campaign Pitch) (Ln(Risks and Challenges)). In Column (2) of Panel A (Panel B), Readability is measured as the additive inverse of the Flesch-Kincaid grade level of the campaign pitch (risks and challenges section). In Column (3) of Panel A (Panel B), Sentiment is measured as (Number of positive words - Number of negative words)/(Number of positive 
words + Number of negative words) of the campaign pitch (risks and challenges section). In Column (4) of Panel A (Panel B), Lexical Diversity is measured as the Carroll's Corrected Type-Token ratio (CTTR) for the campaign pitch (risks and challenges section). In Column (5) of Panel A (Panel B), Legalese is an indicator variable set equal to one if the campaign pitch (risks and challenges section) contains legal terms, and zero otherwise. In Column (6) of Panel A (Panel B), Quantitative Information is measured as the number of numerals in the campaign pitch (risks and challenges section) (including numbers and words expressing numbers). All model specifications are estimated using OLS and include project, creator, and macro-level control variables, as well as state and subcategory $\times$ year-month fixed effects. The table reports (in parentheses) $t$ statistics based on heteroscedasticity-robust standard errors clustered by state and year-month. ***, **, and * denote statistical significance at the $1 \%$, $5 \%$, and $10 \%$ levels (two-tailed), respectively. All variables are defined in Appendix B. 


\section{Table 9: Disclosure Costs}

Panel A: Proprietary Costs of Disclosure

\begin{tabular}{|c|c|c|c|c|}
\hline \multirow[b]{4}{*}{ Independent variables: } & \multicolumn{2}{|c|}{ "Dependent variable: Ln(Campaign Pitch) } & \multirow{2}{*}{\multicolumn{2}{|c|}{ Dependent variable: Ln(Risks and Challenges) }} \\
\hline & \multicolumn{2}{|c|}{ Innovative Project } & & \\
\hline & No & Yes & No & Yes \\
\hline & (1) & (2) & (3) & (4) \\
\hline Post $\times$ Treated & $\begin{array}{l}0.004 * * * \\
(3.96)\end{array}$ & $\begin{array}{l}0.002 * * \\
(2.06)\end{array}$ & $\begin{array}{l}0.003 * * \\
(2.44)\end{array}$ & $\begin{array}{r}0.001 \\
(0.96)\end{array}$ \\
\hline Project controls & Yes & Yes & Yes & Yes \\
\hline Creator controls & Yes & Yes & Yes & Yes \\
\hline Macro controls & Yes & Yes & Yes & Yes \\
\hline State fixed effects & Yes & Yes & Yes & Yes \\
\hline Subcategory $\times$ Year-month fixed effects & Yes & Yes & Yes & Yes \\
\hline $\begin{array}{l}\text { Test for difference in Post } \times \text { Treated } \\
\chi^{2} \text {-test p-value: } N o=Y e s\end{array}$ & & & & \\
\hline Obs. & 77,152 & 177,865 & 55,265 & 133,650 \\
\hline Adj. $\mathrm{R}^{2}$ & 0.311 & 0.391 & 0.298 & 0.205 \\
\hline
\end{tabular}


Table 9 (continued)

Panel B: Direct Costs of Disclosure

\begin{tabular}{|c|c|c|c|c|c|c|}
\hline \multirow[b]{3}{*}{ Independent variables: } & \multicolumn{2}{|c|}{ Dependent variable: Creator Involvement } & \multicolumn{2}{|c|}{ Dependent variable: Ln(Creator Replies) } & \multicolumn{2}{|c|}{ Dependent variable: Ln(Creator Replies Length) } \\
\hline & $\begin{array}{l}\text { Disclosure variable: } \\
\text { Ln(Campaign Pitch) }\end{array}$ & $\begin{array}{c}\text { Disclosure variable: } \\
\text { Ln(Risks and Challenges) }\end{array}$ & $\begin{array}{l}\text { Disclosure variable: } \\
\text { Ln(Campaign Pitch) }\end{array}$ & $\begin{array}{c}\text { Disclosure variable: } \\
\text { Ln(Risks and Challenges) }\end{array}$ & $\begin{array}{l}\text { Disclosure variable: } \\
\text { Ln(Campaign Pitch) }\end{array}$ & $\begin{array}{c}\text { Disclosure variable: } \\
\text { Ln(Risks and Challenges) }\end{array}$ \\
\hline & $(1)$ & (2) & (3) & (4) & $(5)$ & (6) \\
\hline Disclosure & $\begin{array}{l}0.708^{* * *} \\
(8.98)\end{array}$ & $\begin{array}{l}0.560 * * * \\
(6.95)\end{array}$ & $\begin{array}{l}0.052 * * * \\
(5.78)\end{array}$ & $\begin{array}{l}0.020^{*} \\
(1.70)\end{array}$ & $\begin{array}{l}0.171^{* * *} \\
(7.46)\end{array}$ & $\begin{array}{l}0.074 * * \\
(2.43)\end{array}$ \\
\hline Post $\times$ Treated & $\begin{array}{l}-0.632^{* * *} \\
(-9.18)\end{array}$ & $\begin{array}{l}-0.378^{* * *} \\
(-7.95)\end{array}$ & $\begin{array}{l}-0.015^{* * *} \\
(-4.31)\end{array}$ & $\begin{array}{l}-0.007 * * * \\
(-3.78)\end{array}$ & $\begin{array}{l}-0.034 * * * \\
(-3.27)\end{array}$ & $\begin{array}{l}-0.023 * * * \\
(-2.74)\end{array}$ \\
\hline Disclosure $\times$ Post & $\begin{array}{c}0.058 \\
(0.60)\end{array}$ & $\begin{array}{r}0.009 \\
(0.12)\end{array}$ & $\begin{array}{l}0.006^{* *} \\
(2.45)\end{array}$ & $\begin{array}{l}0.007^{* * *} \\
(3.80)\end{array}$ & $\begin{array}{r}0.009 \\
(1.52)\end{array}$ & $\begin{array}{l}0.012^{*} \\
(1.98)\end{array}$ \\
\hline Disclosure $\times$ Treated & $\begin{array}{l}-0.055^{* * *} \\
(-6.97)\end{array}$ & $\begin{array}{l}-0.051 * * * \\
(-5.60)\end{array}$ & $\begin{array}{c}0.001 \\
(1.44)\end{array}$ & $\begin{array}{r}0.002 \\
(1.20)\end{array}$ & $\begin{array}{l}0.005^{*} \\
(1.87)\end{array}$ & $\begin{array}{r}0.005 \\
(1.22)\end{array}$ \\
\hline Disclosure $\times$ Post $\times$ Treated & $\begin{array}{l}0.108^{* * *} \\
(9.58)\end{array}$ & $\begin{array}{l}0.091^{* * * *} \\
(8.94)\end{array}$ & $\begin{array}{l}0.002^{* * *} \\
(3.69)\end{array}$ & $\begin{array}{l}0.001^{* * *} \\
(3.34)\end{array}$ & $\begin{array}{l}0.005^{* * *} \\
(2.88)\end{array}$ & $\begin{array}{l}0.005^{* *} \\
(2.40) \\
\end{array}$ \\
\hline Project controls & Yes & Yes & Yes & Yes & Yes & Yes \\
\hline Creator controls & Yes & Yes & Yes & Yes & Yes & Yes \\
\hline Macro controls & Yes & Yes & Yes & Yes & Yes & Yes \\
\hline State fixed effects & Yes & Yes & Yes & Yes & Yes & Yes \\
\hline Subcategory $\times$ Year-month fixed ef & fects & Yes & Yes & Yes & Yes & Yes \\
\hline Obs. & 255,017 & 188,915 & 255,017 & 188,915 & 255,017 & 188,915 \\
\hline Adj. $\mathrm{R}^{2}$ & 0.194 & 0.206 & 0.336 & 0.358 & 0.321 & 0.346 \\
\hline
\end{tabular}

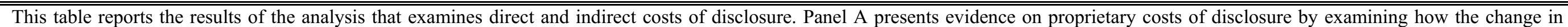

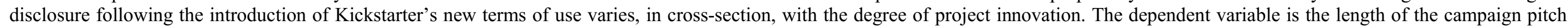

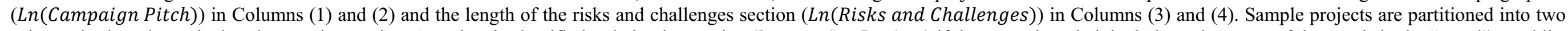

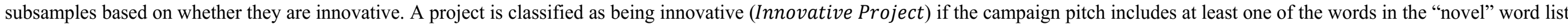

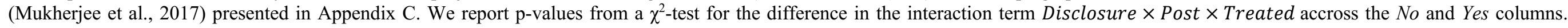

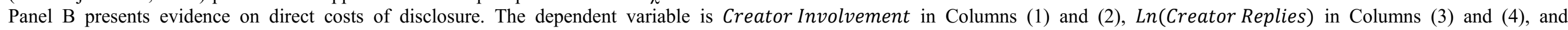

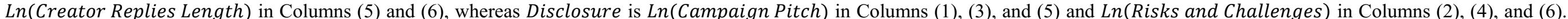

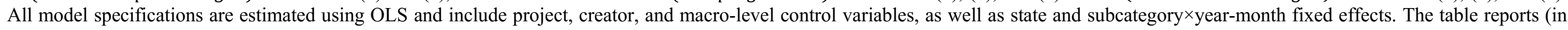

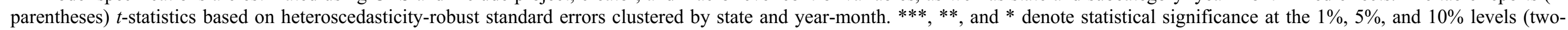
tailed), respectively. All variables are defined in Appendix B. 


\title{
Online Appendix for
}

\section{Does Consumer Protection Enhance Disclosure Credibility in Reward Crowdfunding?}

\author{
Stefano Cascino \\ London School of Economics \\ s.cascino@1se.ac.uk \\ Maria Correia \\ London School of Economics \\ m.m.correia@1se.ac.uk \\ Ane Tamayo \\ London School of Economics \\ a.m.tamayo@1se.ac.uk
}




\section{Table of Contents}

1. Change in Perceptions of Creator Legal Liability and Backer Legal Protection

1.1. Announcement of the Change in Kickstarter's Terms of Use

1.2. Media Coverage of the Change in Kickstarter's Terms of Use

1.3. Reactions to the Change in Kickstarter's Terms of Use on Twitter

1.4. FTC Consumer Complaints and Backer Comments

2. Why Did Kickstarter Change Its Terms of Use?

3. Disclosure and Project Success by Size

4. Additional Robustness Tests

5. Treatment Effect Stability

6. Additional Evidence on Disclosure Changes

Figure OA-1: Example of Kickstarter Project

Figure OA-2: Number of Projects

Figure OA-3: Average Successful Projects

Figure OA-4: Total Amount Pledged

Figure OA-5: Kickstarter's Announcement of Its New Terms of Use

Figure OA-6: Collection of Tweets Discussing the Change in Kickstarter's Terms of Use Figure OA-7: Google Search Interest for Kickstarter Rules

Figure OA-8: Kickstarter Web Traffic

Figure OA-9: Aggregate Goal and Amount Pledged

Figure OA-10: Keyness of Project Disclosures

Table OA-1: Excerpts from Articles Covering the Change in Kickstarter's Terms of Use

Table OA-2: Web Traffic of Publications Covering the Change in Kickstarter's Terms of Use

Table OA-3: FTC Consumer Complaints and Backer Comments

Table OA-4: Disclosure and Project Success by Size

Table OA-5: Additional Robustness Tests

Table OA-6: Treatment Effect Stability 


\section{Change in Perceptions of Creator Legal Liability and Backer Legal Protection}

A maintained assumption underlying our test design is that, while prior to the rule change there was limited awareness that consumer protection laws would apply to Kickstarter creators and backers (see Ganatra, 2016), the revision of Kickstarter's terms of use altered perceptions of creator legal liability and backer legal protection. In other words, we contend that the new rules changed the perceived litigation risk faced by project creators and, consequently, the legal recourse opportunities for backers, even though the actual consumer protection laws did not change. To provide support for this assumption, we take a four-pronged approach. First, we document the different means through which Kickstarter advertised the change in terms of use. Second, we analyze mainstream and tech-dedicated media reactions to the rule change. Third, we investigate how the change in terms of use was discussed on social media. Finally, we conduct empirical tests whose evidence further backs our claim that the rule change significantly increased the awareness of creators and backers regarding the applicability of consumer protection laws to crowdfunding. We explain our approach in more detail in the following sections.

\subsection{Announcement of the Change in Kickstarter's Terms of Use}

We explore how Kickstarter publicized the introduction of its new terms of use. We find that the rule change was widely announced on Kickstarter's website, on social media, as well as via email to all registered users (including all prior or current backers and creators registered on the website).

We present evidence on the different means used by Kickstarter to publicize its new terms of use in Figure OA-5. Given the extensive coverage and wide reach of the announcement, we believe it is very unlikely that Kickstarter's registered users, social media followers, backers, and creators were not aware of the rule change. 


\subsection{Media Coverage of the Change in Kickstarter's Terms of Use}

We conduct an in-depth analysis of the (mainstream and tech-dedicated) media coverage of the change in terms of use. This rule change drew the attention of both types of media and led to extensive discussions on how the new terms of use would alleviate moral hazard problems by introducing the possibility of legal action by backers. Table OA-1 presents a collection of excerpts from articles announcing and describing the change in terms of use. These articles specifically emphasize the increased litigation risk faced by project creators.

Naturally, tech-dedicated outlets, such as TechCrunch, Ars Technica, Polygon, Engadget, SlashGear, and CNET, make up for a substantial portion of the press coverage. In fact, a Washington Post article highlights that much of the news coverage related to Kickstarter is usually in "news blogs devoted to nerd culture." Many of these outlets have a very large readership. Table OA-2 presents web traffic estimates for the online publications listed in Table OA-1. TechCrunch (a Bay Area online publisher focusing on technology news and profiling of new tech businesses and products), for example, has more than 25 million monthly visits. Ars Technica, Polygon, and Engadget, which are somewhat similar and mainly cover news on technology, video games, and consumer electronics, are estimated to have 30, 34, and 37 million monthly visits, respectively. CNET.com, in turn, had approximately 166 million visits per month in February 2019 (330 million visits at the time of the change in Kickstarter's terms of use). CNET's web traffic is comparable to that of the Washington Post. This type of outlets is of particular interest to the typical Kickstarter creator and backer. In fact, according to Quantcast, a company which specializes in the measurement of websites' audience, the typical Kickstarter.com visitor from 2012 to 2014 read TechCrunch. ${ }^{1}$

\footnotetext{
${ }^{1}$ Quantcast stopped measuring and tracking the audience of Kickstarter.com in 2014. We retrieve Kickstarter's traffic and demographic statistics published by Quantcast from 2012 to 2014 using the Wayback Machine.
} 
These tech-outlets emphasized to a large extent the increased legal liability of creators and the increased legal protection of backers. For example, on September 19, 2014, TechCrunch published an article stating:

"Kickstarter also reminds creators that they need to be "honest" and not make "material misrepresentations in their communication to backers." (In other words, scammers beware.) Additionally, the terms now state that creators who are unable to stand by the promises they made in their project may be subject to legal action by backers."

Other online publications followed suit, with Polygon and SlashGear, for example, emphasizing that creators not delivering rewards "open themselves up to possible legal action from backers" and respectively using the following headlines to advertise the change: "Kickstarter updates terms to address creators who fail to deliver on their projects" and "Kickstarter changes rules so nobody runs off with your money."

While this change naturally received more attention from online outlets devoted to technology and gaming, it was also covered by the mainstream media, including NBC News, Time Magazine, and the Washington Post. ${ }^{2}$ For example, NBC News reported:

"Kickstarter is trying to codify the current swampy situation around projects canceled after creators have the cash in hand. (...) If creators don't make good on the promises made in their campaigns, they must explain what happened, return any unused funds, and could face potential legal action from backers."

Time Magazine highlighted the difference between moral hazard problems (i.e., making deceitful disclosures and then taking the money and running) and bad business decisions, clarifying that the former may lead to legal action following the rule change:

"In the event that a scammer takes everyone's money and runs, Kickstarter won't offer a refund or even chip in for legal fees. But at least in those cases there's a clear basis for taking legal action (fraud); when money is squandered in a more conventional way - through bad business decisions - funders have no recourse at all."

\footnotetext{
2 The subsequent 2015 actions by the Federal Trade Commission (FTC) against Erik Chevalier (the creator of "The Doom That Came To Atlantic City") and by the Washington State Attorney General against Ed Nash (the creator of "Asylum Playing Cards") were also extensively covered by both specialized blogs and the mainstream media (e.g., CNN, Washington Post, New York Times, Forbes, Newsweek, and Huffington Post).
} 
Collectively, the analysis of the media coverage suggests that the media found the change in terms of use to be meaningful and consequential and to have implications for creator accountability and backer protection.

\subsection{Reactions to the Change in Kickstarter's Terms of Use on Twitter}

To gain additional insights into how backers and creators perceived the rule change, we next investigate whether and how the change in Kickstarter's terms of use was discussed on social media. We believe this type of analysis can bring. In Figure OA-6, we present a collection of "tweets" surrounding the rule change. These tweets provide interesting anecdotal evidence on how potential backers and creators reacted to the change in Kickstarter's terms of use. Several Twitter users highlighted the importance of the change. For example:

$\begin{array}{ll}\text { @icotom: } & \text { "@kickstarter has updated their TOS. Very } \\ & \text { interesting read, quite important clarifications" } \\ \text { @PixelPiracyGame: } & \text { "Seems like a HUGE step forward for } \\ & @ \text { Kickstarter" }\end{array}$

More importantly, several users emphasized the heightened creator accountability:

@milesmaker: “Kickstarter's New Rules: You can't just take your \$ and run. Complete projects, or fess up!"

Others emphasized how the new rules protect backers:

$\begin{array}{ll}\text { @ElanAmran: } & \text { "\#Kickstarter Releases New \#Crowdfunding Rules to } \\ & \text { Protect Buyers" } \\ \text { @LK617: } & \text { "New \#Kickstarter terms of use protect backers when } \\ & \text { projects fail" } \\ \text { @booksofm: } & \text { "Iwonder if the new Kickstarter Terms of Use basically } \\ & \text { means if you don't deliver what you promise you are } \\ & \text { open to a Class Action" }\end{array}$

Combined, the anecdotal evidence presented in Sections 1.1 to 1.3 supports our assumption that (potential) backers and creators were indeed aware of the rule change and its implications in terms of increased creator legal liability and backer legal protection. In fact, given the way in which Kickstarter disclosed the change in terms of use, the coverage of this 
change by mainstream and specialized media outlets, and the discussion that ensued on social media, it is unlikely that users of Kickstarter were unaware of the rule change and its implications. Nevertheless, in Section 1.4, we conduct a series of empirical tests to provide further support to the key underlying assumption of our research design.

\subsection{FTC Consumer Complaints and Backer Comments}

To offer further support to our maintained assumption that the change in Kickstarter's terms of use changed the perceptions of creators and backers regarding the applicability of preexisting state consumer protection regulation to reward crowdfunding, we conduct two sets of empirical tests. First, we investigate whether the number of consumer complaints increases following the introduction of the new terms of use. Second, we check backer comments to examine whether, following the introduction of the new terms of use and the resulting increase in creator legal liability, backer satisfaction increases and the number of fraudulent campaigns and projects with delayed reward delivery decreases.

We made a request to the Federal Trade Commission (FTC) under the Freedom of Information Act (FOIA) for a list of all consumer complaints involving the Kickstarter platform. The list we obtained from the FTC includes 369 complaints made as of September 4, 2018. While project names and backer (consumer) identifying information are unavailable to us because redacted, the file we received from the FTC contains information regarding the address (and state) of each consumer making a complaint. This information allows us to test whether the number of consumer complaints increases following the change in Kickstarter's terms of use, and whether this increase is more pronounced in states with stricter consumer protection laws, consistent with the role of consumer protection becoming more salient to backers subsequent to the rule change. ${ }^{3}$

\footnotetext{
${ }^{3}$ Note that these are federal (and not state) consumer complaints. Nonetheless, we expect to find a large increase in complaints in states with stronger consumer protection regulation, that is, where consumer rights are more salient.
} 
The increase in consumer complaints appears evident from simple descriptive statistics: backers made 51 complaints to the FTC in the 64 months preceding the change in terms of use and 315 complaints in the 59 months that followed it (three additional complaints were made in the month of the rule change, September 2014).

To further examine whether the effect of the change in terms of use varies across states with different levels of consumer protection, we regress the number of complaints by state and year-month on the interaction term Post $\times$ Treated. Our model specification includes state and year-month fixed effects to control for state and year-month unobservable factors and, therefore, excludes the main effects of Treated and Post, as these variables are collinear with the state and year-month fixed effects, respectively. The results of this analysis are presented in Column (1) of Table OA-3. The coefficient on Post $\times$ Treated is positive and significant, suggesting that, following the change in terms of use, the number of consumer complaints increases in states with stronger consumer protection laws. In untabulated tests, we further control for the number of projects in each state and year. The statistical significance and economic magnitude of the coefficient on Post $\times$ Treated remain unchanged.

To assess whether the change in consumer protection was followed by an improvement in backer satisfaction and a decrease in the number of projects with delayed reward delivery and projects that bakers allege as fraudulent, we conduct a textual analysis of backer comments. We restrict our analysis to comments made by backers of successfully-funded projects after the end of the funding period. We begin by estimating the sentiment of backer comments for each funded project and compute the average backer sentiment of all projects in a given state and year-month. We then identify comments that mention the terms "fraud," "delay," and/or respective synonyms, and compute the percentage of successfully-funded projects in a given state and year-month with comments that include each of these sets of words. Our empirical tests, reported in Columns (2) to (4) of Table OA-3, suggest an increase in the sentiment of backers, a lower incidence of reward delivery delays, and a lower percentage of projects with 
fraud allegations in states with stricter consumer protection following the change in terms of use.

The combined anecdotal and empirical evidence presented in this section strongly backs our assumption that perceptions of creator legal liability and backer legal protection indeed changed following the introduction of Kickstarter's new terms of use.

\section{Why Did Kickstarter Change Its Terms of Use?}

In this section, we discuss potential factors that may have influenced Kickstarter's decision to revise its terms of use and how we control for these factors in our empirical analysis. When Kickstarter announced the change in terms of use on its blog, it indicated that the goal of the change was to "make sure every part of the Kickstarter system is clear and straightforward." An analysis of Twitter activity, Google searches, news articles, and websites related to technology and crowdfunding suggests that the change in terms of use may have been prompted by the negative coverage received by a set of highly-publicized projects that may have led Kickstarter to consider potential reputational costs. This idea is echoed by some of the Twitter activity surrounding the change. For example:

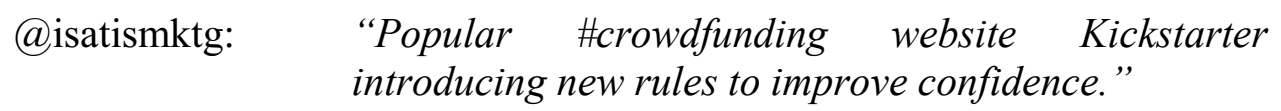

In the months preceding the rule change, the number of Google searches for Kickstarter rules increased (see Figure OA-7). This increasing interest suggests that the decision to clarify the nature of the contract between backers and creators, and clearly spell out the possibility of legal action, may have been driven by increased uncertainty regarding the rights and obligations of backers and creators, respectively.

Another related factor that may have played a role is Kickstarter's desire to clarify that the platform bears no legal responsibility for funded projects that do not deliver rewards. In fact, the new terms of use specifically state: "Kickstarter is not part of this contract - the 
contract is a direct legal agreement between creators and their backers." They further include a section titled "Stuff we don't do and aren't responsible for," in which Kickstarter specifically states that they "don't oversee the performance or punctuality of projects" and "don't endorse any content users submit to the Site."

To assess whether the change in terms of use might have been triggered also by other factors, we further examine the volume of web traffic on Kickstarter.com (Figure OA-8). While web traffic had been steadily increasing since the creation of the website in 2009 , it experienced a deceleration in growth, or even a slight decline, in the months that preceded the change in terms of use. Web traffic then increased again following the change. This pattern could also be consistent with increased uncertainty regarding the contractual arrangement between backers and creators and their respective rights and obligations, which was then resolved by the rule change. We do not control for this last set of factors (Google searches, web traffic, and number of projects receiving negative attention) in our analysis as these are effectively subsumed by our subcategory×year-month fixed effects. ${ }^{4}$

Finally, in Figure OA-9, we report Kickstarter's aggregate goal and amount pledged. Note that the main source of Kickstarter's revenues are the fees it receives for successfullyfunded projects. These fees are defined as a percentage of the total amount pledged by backers. While Kickstarter had been experiencing an increase in the total goal amount (i.e., the total amount of funds requested by creators) leading up to the change in terms of use, this increase was not accompanied by a comparable increase in the amount of funds pledged by backers. It is possible, therefore, that the change in rules was also driven by a relative decrease in amount pledged..$^{5}$ As this could be a potentially important trigger of the rule change whose effect would not be absorbed by our fixed effects structure, we include lagged aggregate amount pledged as

\footnotetext{
${ }^{4}$ Note that Google Trends data and web traffic data are only available at the aggregate year-month level.

${ }^{5}$ Note that, in absolute terms, amount pledged continued to increase throughout our sample period.
} 
a percentage of aggregate goal amount at the state and year-level as an additional control in our model specifications. ${ }^{6}$

\section{Disclosure and Project Success by Size}

In Table OA-4, we examine the extent to which the association between project success and disclosure is observed across different project size (i.e., funding goal) categories. We find that project success exhibits a positive and significant association with disclosure across all size categories. A one standard deviation increase in the length of the campaign pitch (risks and challenges section) is associated with a 1.2 to 2.0 ( 0.8 to 2.3$)$ percentage points increase in probability of success and a U.S. \$146 to U.S. \$955 (U.S. \$111 to U.S. \$465) increase in amount pledged.

\section{Additional Robustness Tests}

In this section, we present a set of sensitivity tests assessing the robustness of our findings. Our main analyses are based on the location of the project (as opposed to the location of the project backers). This research design choice is supported by the following two arguments. First, if a creator is a resident of a given state and does substantial business (i.e., it markets, advertises, distributes, sells, and receives substantial profits from sales) within that state, then the appropriate venue for a consumer protection lawsuit would be that specific state. Second, prior literature documents a significant home-bias even though crowdfunding is not geographically constrained (Agrawal et al., 2011, Lin and Viswanathan, 2015). Nevertheless, to the extent that certain project locations are different from the location of their backers, location may be measured with error. ${ }^{7}$ To alleviate this concern, we conduct a sensitivity test in which we limit our sample to projects for which most backers reside in the project state.

\footnotetext{
${ }^{6}$ In the model specifications presented in Table 4, Panel $\mathrm{C}$ of the paper, our state $\times$ year-month fixed effects effectively absorb the effect of lagged aggregate amount pledged.

${ }^{7}$ Note that, for our identification to lead to a biased estimate of the effect of the rule change, the proportion of backers located outside of the project state would have to be correlated with the treatment.
} 
Kickstarter provides information (in the community tab) on the top 10 cities in which backers are located, as well as on the number of backers in each of these cities. Based on these data, we compute the percentage of project backers that hail from the project state. Note that our measure is conservative, as we are only able to observe backers in the top 10 cities. We limit our sample to projects for which more than $50 \%$ of backers are in the project state. Table OA-5, Panel A, presents the results of this analysis. We find that the coefficient on our variable of interest, Disclosure $\times$ Post $\times$ Treated, is positive and significant across all disclosure and project success proxies. The fact that we observe an increase in the credibility of the campaign pitch (risks and challenges section) in this subsample of 30,351 $(22,585)$ observations increases our confidence in the robustness of our main findings.

Moreover, because some of the projects in our sample have been cancelled or suspended, project success may also be measured with error. When a project is cancelled or suspended by Kickstarter or directly by creators, the reason for the lack of success may not be related to the unwillingness of backers to support that project. Yet, in our main analysis we code such projects as unfunded (i.e., Funded is equal to 0). To alleviate the concern that our findings may be driven by potential measurement error, we conduct further sensitivity tests in which we exclude cancelled and suspended projects from our sample. Table OA-5, Panel B, reports the results of these tests. The coefficient on the interaction term Disclosure $\times$ Post $\times$ Treated remains significantly positive across all disclosure and project success proxies also within this smaller subsample.

Finally, some creators may return to Kickstarter multiple times with different projects hence building reputation. The effect of disclosure on project success may thus be confounded by the performance of creators in previous campaigns. To allay this concern, in Table OA-5, Panel C, we limit our sample to projects of first-time creators. We continue to find an increase in the credibility of disclosure following the rule change across all disclosure and project success proxies. 


\section{Treatment Effect Stability}

While the different fixed effects structures that we employ in the tests presented in Table 4, Panel $\mathrm{C}$ and the results of our cross-sectional tests presented in Table 6 already alleviate, to a great extent, a potential omitted variable bias in our empirical analysis, in this section we implement the bounding methodology proposed by Oster (2019) to assess the stability of our treatment effects and evaluate their robustness to omitted variable bias.

Specifically, we re-estimate our main model specifications (Table 3, Panel A, Columns (2) and (4) and Table 3, Panel B, Columns (1) and (2) of the paper) with and without project, creator, and macro-level control variables. We then assume a value for $\mathrm{R}^{\max }$ (the $\mathrm{R}^{2}$ from a hypothetical regression of the outcome on treatment and both observed and unobserved control variables) and, based on this assumption, calculate the value of delta (the relative degree of selection on observed and unobserved control variables) for which the treatment effect would be zero. Delta is a function of $\mathrm{R}^{\max }$ and the change in the coefficient on Post $\times$ Treated $\times$ Disclosure and $\mathrm{R}^{2}$ as the control variables are included in the regression. Following Oster (2019), we set $\mathrm{R}^{\max }$ equal to 1.3 multiplied by the $\mathrm{R}^{2}$ of the regression that includes all control variables. We present the results of this analysis in Table OA-6. Our deltas range from 1.7 to 2.7 (across the different disclosure and funding variables). This suggests that, depending on the disclosure and funding variable, the unobservables would need to be 1.7 to 2.7 times as important as the observables to produce a treatment effect of zero. When $\mathrm{R}^{\max }$ is set more conservatively to 1.5 multiplied by the $\mathrm{R}^{2}$ of the controlled regression, deltas range from 1 to 1.5 (untabulated). The magnitude of these deltas provides further reassurance that the treatment effect that we document is unlikely to be driven by omitted variables.

\section{Additional Evidence on Disclosure Changes}

Our analysis of the type of language used in project disclosures is based on lists of words. As these lists necessarily involve some discretion, we also examine the keyness (i.e., the 
relative frequency of words) in the campaign pitch and risks and challenges section for projects starting before and after the rule change. Figure OA-10 plots the highest values of the $\chi^{2}$-test statistic for differences in the frequency of words in the "pre" and "post" period. Following the change in Kickstarter's terms of use, creators increasingly use words such as "product," "campaign," "business," "manufacturing," "shipping," "risk," and "documentation" in their campaign pitches. The type of words used in the risks and challenges section also appears to change, with words such as "report," "accountability," "learn," “check," "questions," "campaign," being, for example, more frequently used. In line with our main findings, the evidence emerging from this additional analysis points to an increase in the use of legal, as well as business, terms. 


\section{References}

Agrawal, A, C. Catalini, and A. Goldfarb. 'The geography of crowdfunding.' NBER No. w16820. National Bureau of Economic Research (2011).

Ganatra, J. H. 'When a Kickstarter stops: Exploring failures and regulatory frameworks for the Rewards-Based Crowdfunding Industry.' Rutgers University Law Review 68 (2016): 1425-1472.

Lin, M., and S. Viswanathan. 'Home bias in online investments: An empirical study of an online crowdfunding market.' Management Science 62 (2015): 1393-1414.

Oster, E. 'Unobservable selection and coefficient stability: Theory and evidence.' Journal of Business and Economic Statistics 37 (2019): 187-204. 


\section{Figure OA-1: Example of Kickstarter Project}

\section{Exhibit A: Project Header}

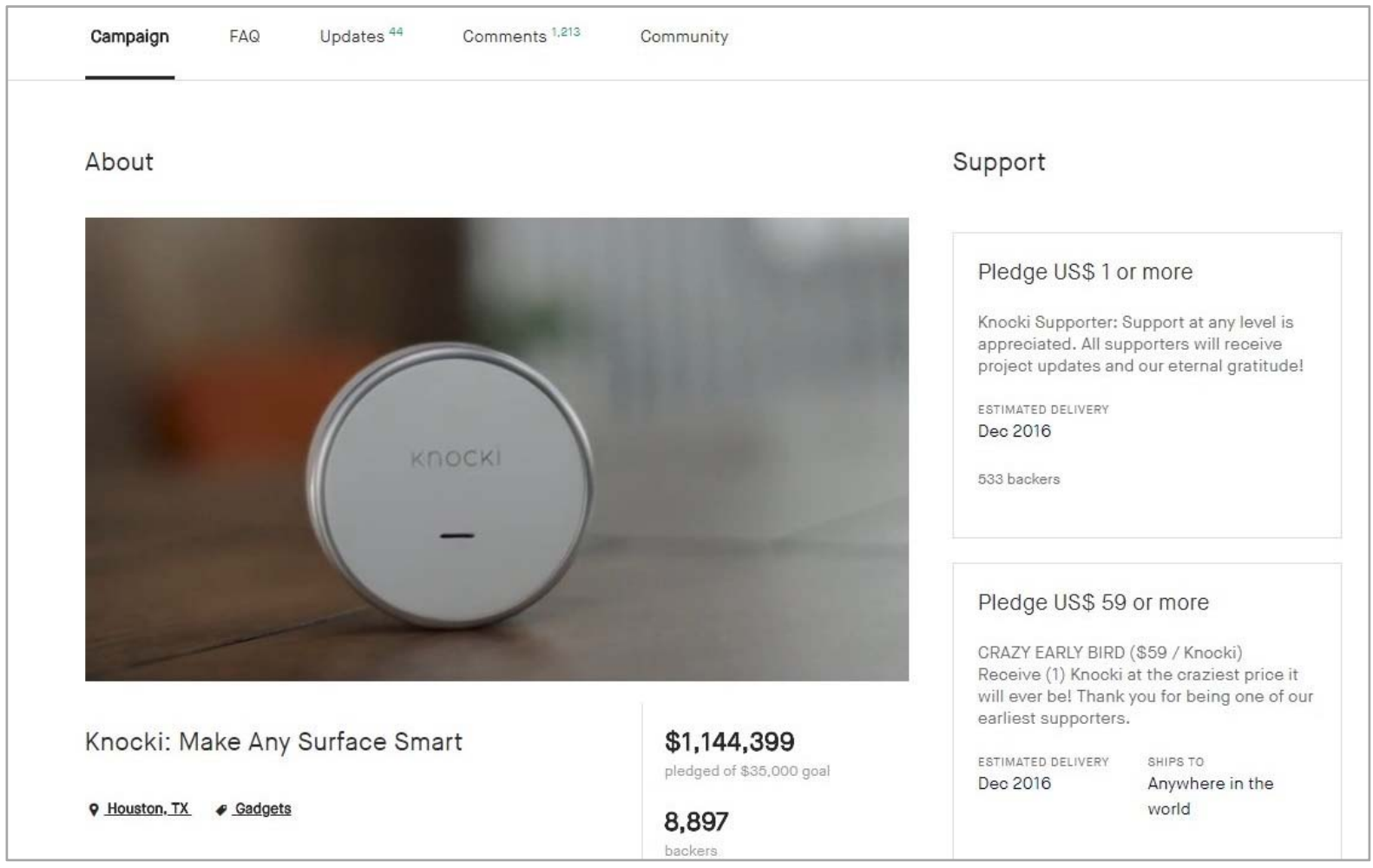

\section{Exhibit B: Campaign Pitch}

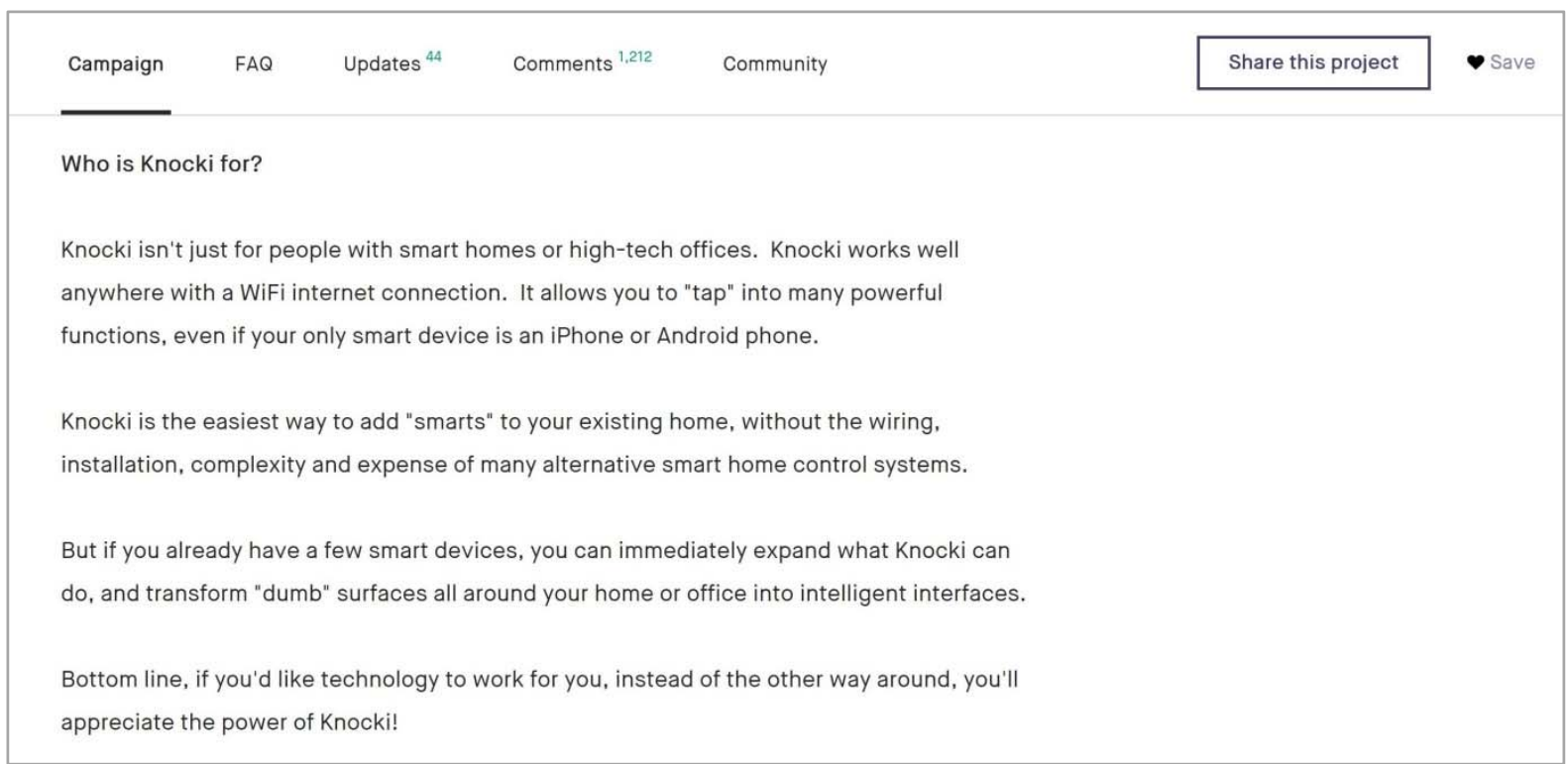




\section{Figure OA-1 (continued)}

\section{Exhibit C: Risks and Challenges Section}

Campaign
Risks and challenges
Knocki isn't some far-fetched idea hacked together in a garage. We're a serious start-up
with a growing full-time team, seed-funding, a production ready working prototype, and lots
of exciting momentum.
We've finalized designs and have engaged a proven domestic manufacturer so we can be
on the ground-floor watching the birth of Knocki! We also have the support of two
accelerators (Seed Sumo \& TechrloT) who have helped us along the way. It's safe to say
that we've reduced many of the risks typical of a hardware startup!
However, as with any newly manufactured product, it's possible for unexpected events to
impact the actual production time frame. On the positive end of the spectrum, we might
deliver them earlier than expected, but we can't rule out the possibility of some delay.
Our commitment to all of you is that we will make every effort to deliver you an exceptional

\section{Exhibit D: Backer Comments}

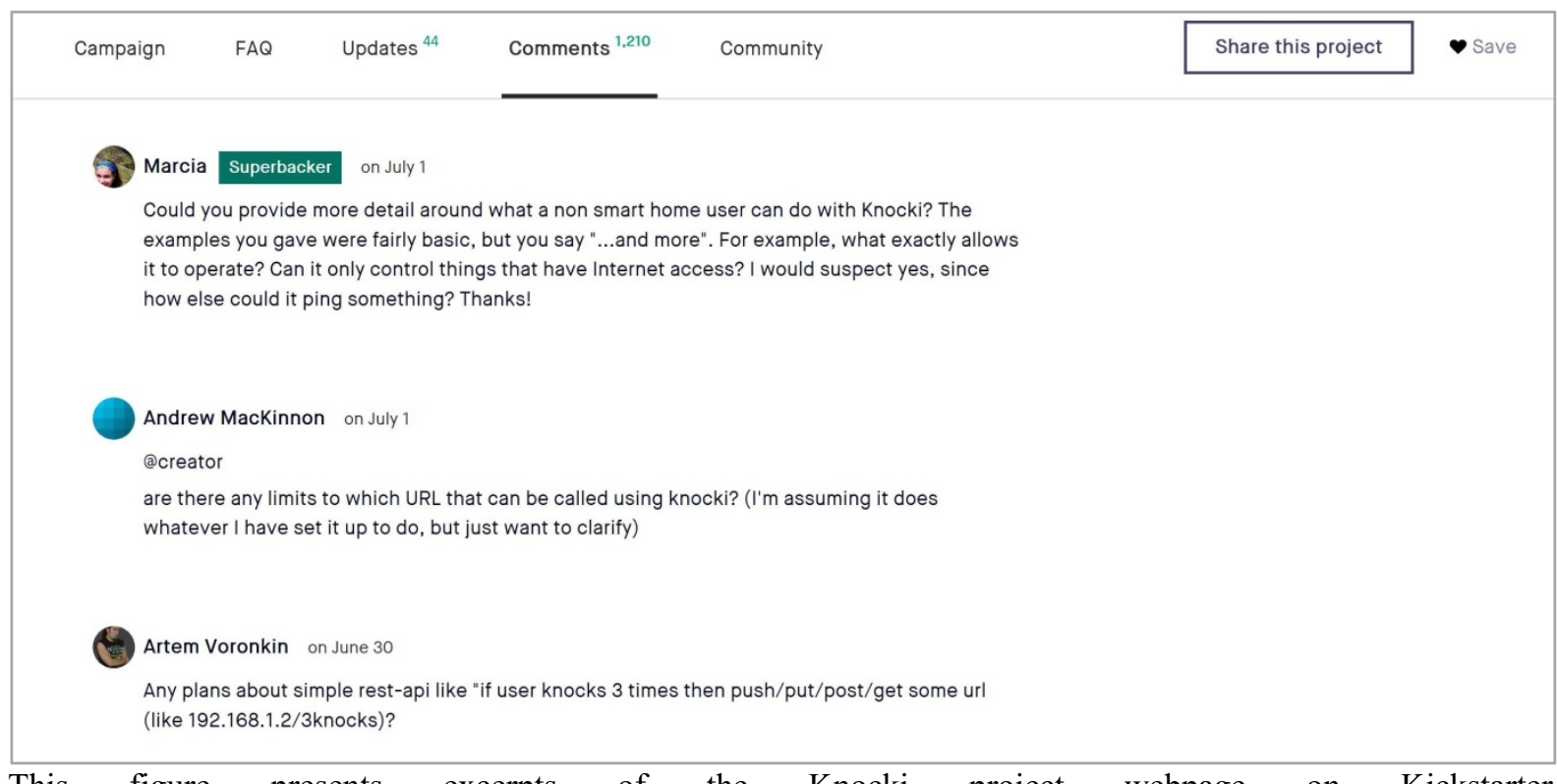

This figure presents excerpts of the Knocki project webpage on Kickstarter

(https://www.kickstarter.com/projects/knocki/knocki-make-any-surface-smart). Exhibits A, B, and C contain snippets of the campaign tab. Exhibit A presents information on project location, category, funding goal, amount pledged, number of backers, and rewards. Exhibits B and C show excerpts of the campaign pitch and risks and challenges section, respectively. Exhibit D provides a snapshot of the project's comments tab. 


\section{Figure OA-2: Number of Projects}

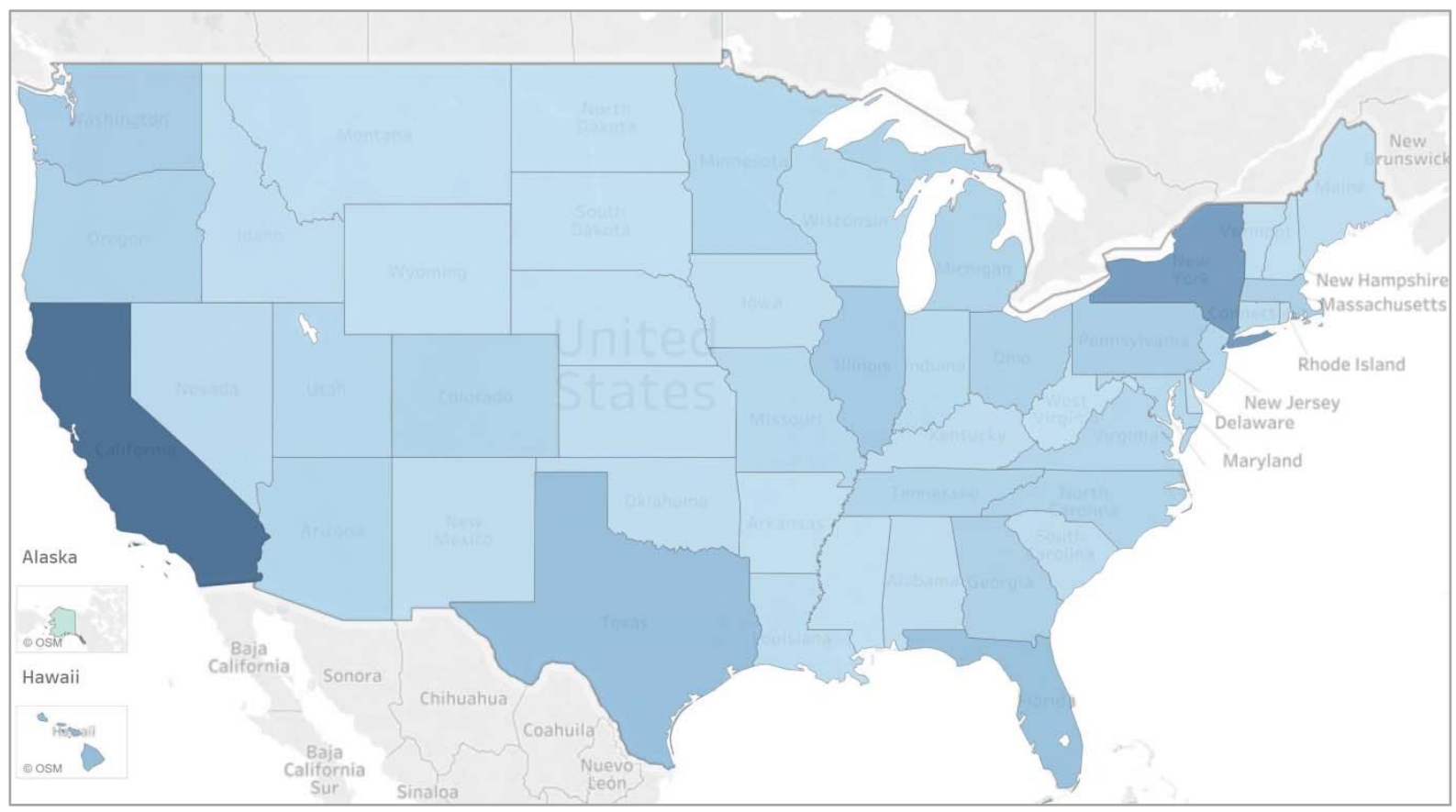

This figure shows the extent of variation in total number of projects on Kickstarter across U.S. states. Dark (light) blue areas indicate a larger (smaller) number of projects.

\section{Figure OA-3: Average Successful Projects}

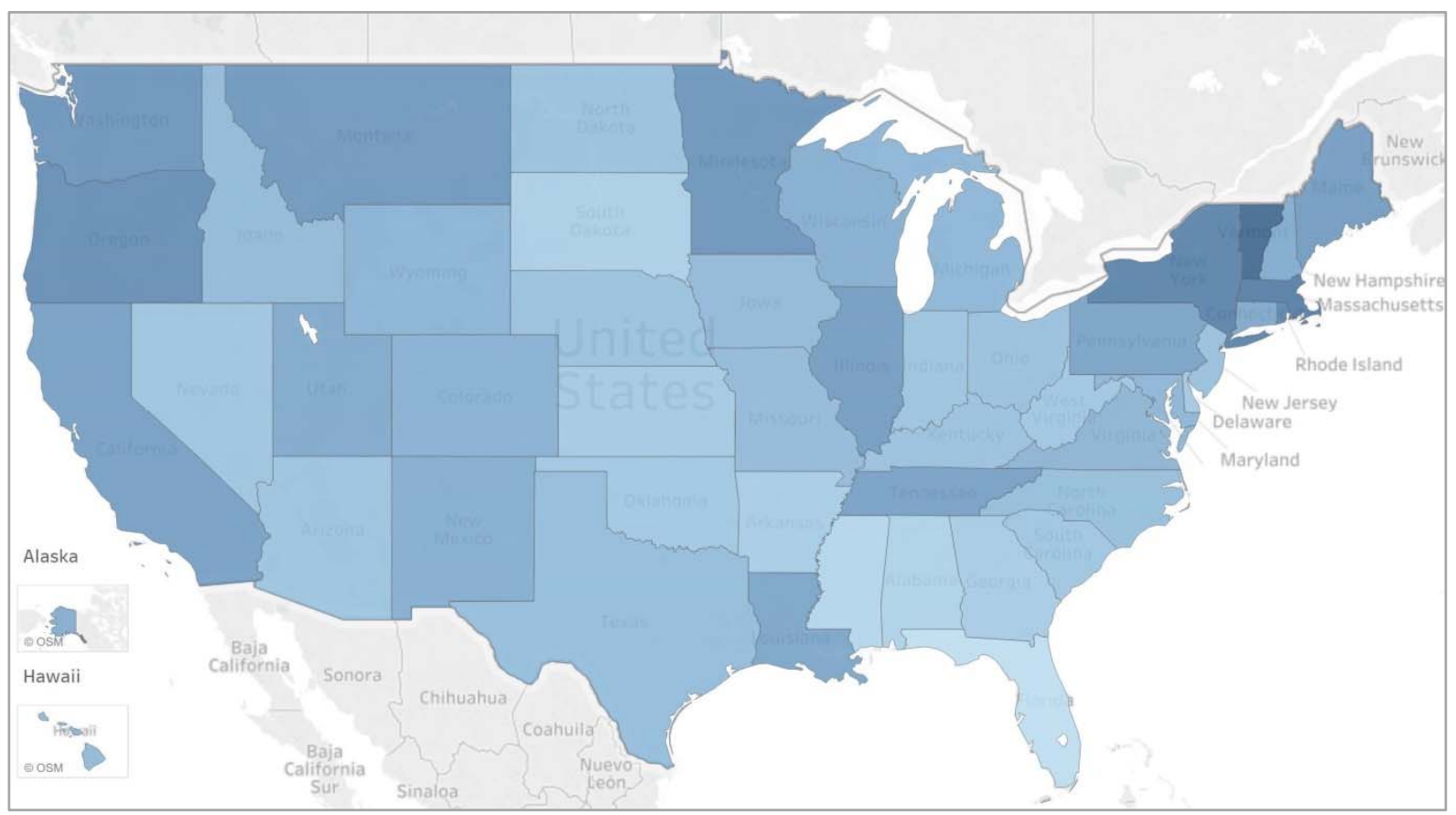

This figure shows the extent of variation in the average number of successful Kickstarter projects across U.S. states. Dark (light) blue areas indicate a higher (lower) average number of successful projects. 
Figure OA-4: Total Amount Pledged

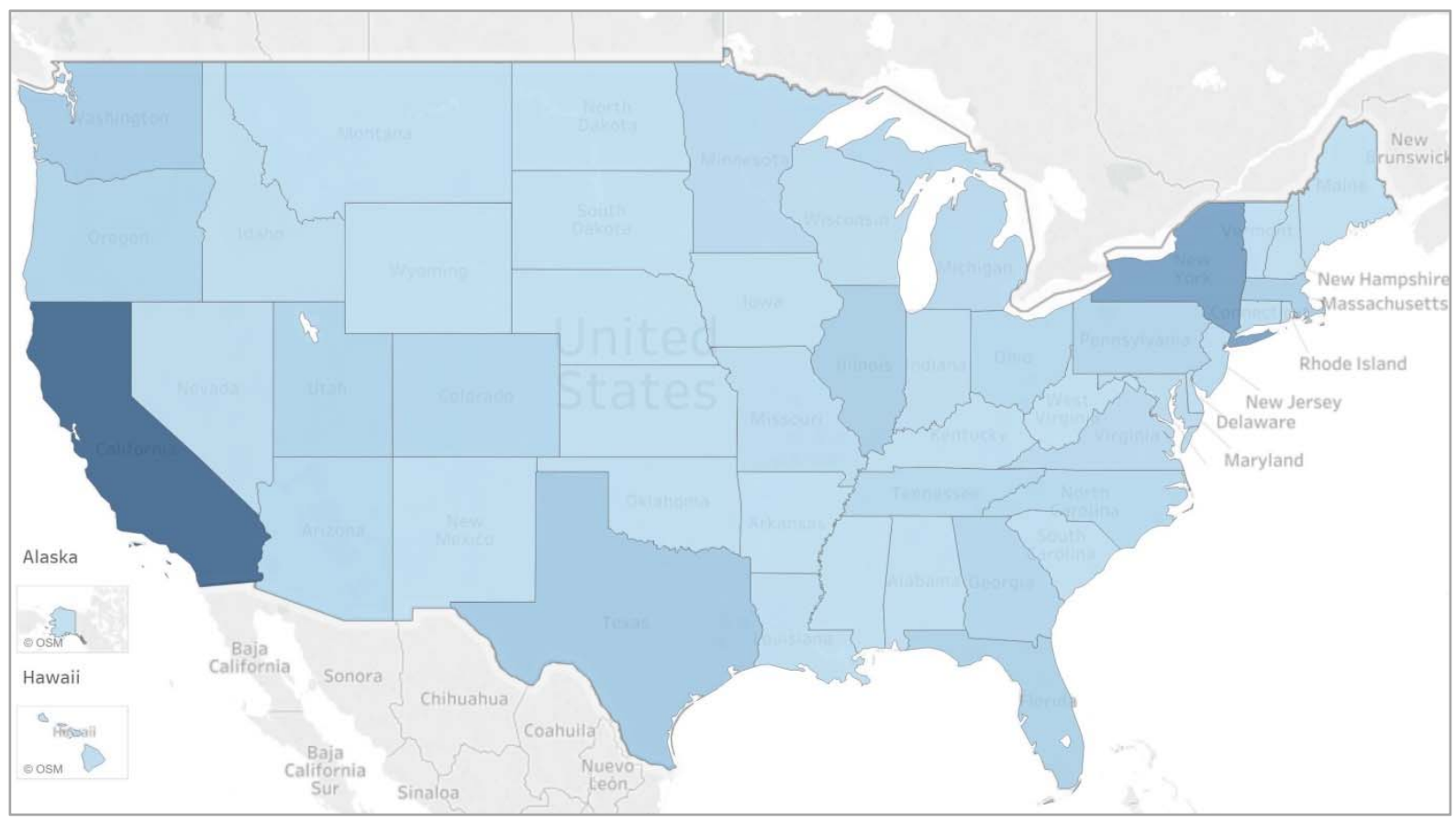

This figure shows the extent of variation in total amount pledged to projects on Kickstarter across U.S. states. Dark (light) blue areas indicate a higher (lower) total amount pledged. 
Figure OA-5: Kickstarter's Announcement of Its New Terms of Use

Exhibit A: Kickstarter Blog

mockstantas

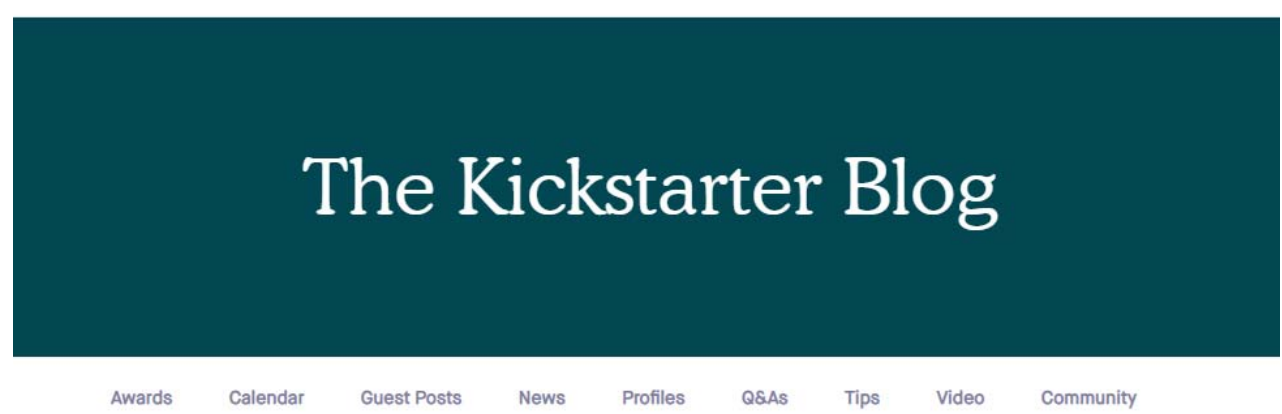

\section{An update to our Terms of Use}

Yancey Strickler

Sep 192014

Exhibit B: Twitter

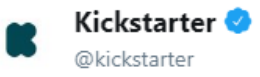

Follow

Today we've announced an update to our Terms of Use:

An update to our Terms of Use

Over the past year, we've been working to make sure every part of the Kickstarter system is clear and straightforward. We've done everything from improving our rules and community guidelines..

KıCKSTARTER kickstarter.com 


\section{Figure OA-5 (continued)}

Exhibit C: Email to Kickstarter's Users

From: Kickstarter $<$ no-reply@kickstarter.com>

Date: Sat, 20 Sep 2014 at 0:04

Subject: An Update to Our Terms of Use

To:

\section{mon STARTE:}

Hi there,

This email is to notify you that we've updated Kickstarter's Terms of Use. You can head over to our blog to learn more about what's changed, but there are three main improvements:

- We've simplified the whole document to make sure it's straightforward and clear.

- We've made a few changes that will allow Kickstarter to open in new countries.

- We've added a detailed outline of what's expected from each Kickstarter project.

You can learn all about it on our blog, or see the full terms here.

Thanks for your time, and thanks for being part of the Kickstarter community.

Kickstarter $\cdot 58$ Kent St, Brooklyn NY 11222

This figure presents Kickstarter's announcement of the change in its terms of use on its website (Exhibit A), on social media (Exhibit B), and via email to its registered users (Exhibit C). 
Figure OA-6: Collection of Tweets Discussing the Change in Kickstarter's Terms of Use

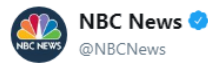

Kickstarter's new rules: Creators must complete projects, or fess up

nbcnews.to/1uT8cBM

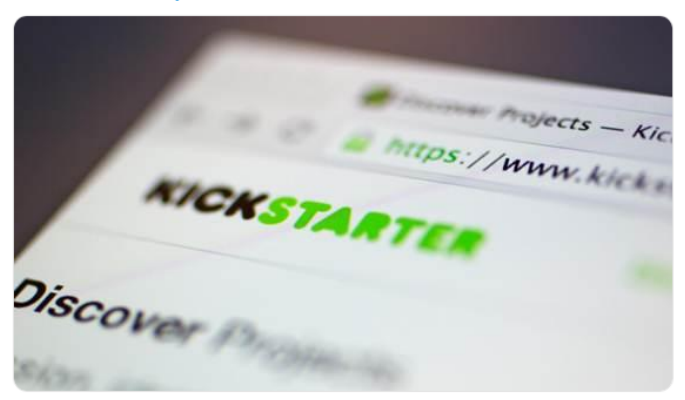

1:54 pm - 22 Sep 2014

67 Retweets 57 Likes 50010

$\begin{array}{llll}7 & \text { L7 } 67 & 0 & 57\end{array}$

A. Thomas Bidaux $\overrightarrow{\text { soow GDC }}$

@icotom

@kickstarter has updated their TOS. Very interesting read, quite important clarifications. Blog post on the changes kickstarter.com/blog/an-update ...

12:08 pm - 19 Sep 2014

$$
\text { ○ } \quad \text { T } 20
$$

\section{Elan Amram}

@ElanAmram

Follow

\#Kickstarter Releases New \#Crowdfunding Rules to Protect Buyers

shmoozbiz.com/CrowdFundingNe ... Please RT

10:17 am - 23 Sep 2014

1 Retweet 2 Likes

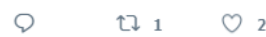

\section{AtomsToBits} @atoms2bits

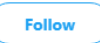

\#Kickstarter Revises 'Terms of Use' to Protect \#Project \#Investors feedproxy.google.com/ r/PFhub/ 3/IS...

11:05 am - 23 Sep 2014

$$
1 \text { Like } \diamond
$$

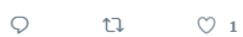

The TechCrunch @

Ahead of new FTC rules, Kickstarter updates Terms of Use section related to failed projects tcrn.ch/1ujX12H

8:00 pm - 19 Sep 2014

53 Retweets 17 Likes 9 (7) $3=0$ - 0 ( )

$D_{2} \quad\left[\begin{array}{lll}53 & O_{17}\end{array}\right.$

FÄKTTRY The Faktory

Follow

Kickstarter's new terms of use: fulfill your campaign promises or risk legal action flip.it/3KuqS \#crowdfunding \#startup

11:30 pm - 19 Sep 2014

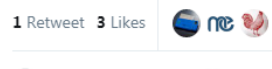

○ โ\ $1 \quad \bigcirc_{3}$

GISA GigaOm *

\#Kickstarter has slowly been improving the rules and guidelines covering the crowdfunding site bit.ly/1r7CoI7

5:02 am - 21 Sep 2014

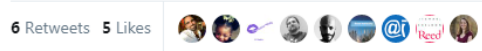

(2) Leora Kornfeld

New \#Kickstarter terms of use protect backers when projects fail

hothardware.com/News/Kickstart ...

10:11 am - 22 Sep 2014

1 Retweet 1 Like

○ โป 1 ○ 1

(2) PFhub

Kickstarter Revises TOS to Protect Project Investors bit.ly/1v4U1Zu \#Kickstarter \#crowdsourcing \#crowdfunding

7:57 am - 23 Sep 2014

○ $\quad$ ᄂ $2 \quad 0$ 


\section{Figure OA-6 (continued)}

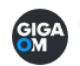

GigaOm

@gigaom

Kickstarter's new terms of use: fulfill your campaign promises or risk legal action wp.me/p10LZV-3Fym

2:00 pm - 19 Sep 2014

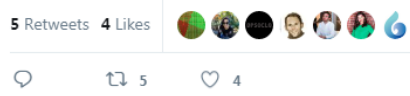

\section{DNet ZDNet} $@ Z D N$

Follow

Kickstarter revamps Terms of Use, straightens out creator accountability zd.net/1B15SIV

1:51 am - 22 Sep 2014

1 Retweet 1 Like

Q ใๆ 1

17 Alain Perocheau

\@isatismktg

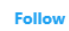

Popular \#crowdfunding website Kickstarter introducing new rules to improve confidence bit.ly/1tVHQiB

9:24 am - 22 Sep 2014

1 Retweet

○ $\uparrow\urcorner$

\section{Pixel Piracy}

$$
\text { @ PixelPiracyGam }
$$

Seems like a HUGE step forward for @Kickstarter. New Rules: Creators Must Complete Projects, or Fess Up nbcnews.to/1siB4EL via @NBCNews

3:09 am - 23 Sep 2014

4 Retweets 3 Likes (ㄱ)

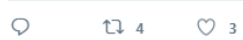

(1) Monica needs moar coffee. 0 (1) Fooksofm

I wonder if the new Kickstarter Terms of Use basically means if you don't deliver what you promise, you're open to a Class Action.

11:50 am - 19 Sep 2014

1 Like $\quad$ PE

$02 \quad 07 \quad 01$

은

Justin D. Jacobson@JustinDJacobson.19 Sep 2014

Replying to @ booksofn

@mlvwrites - short answer, yes. I'm posting something on this later today.

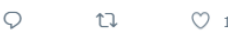

Tracy Barnett @TheOtherTracy · 19 Sep 2014

Replying to @booksofm

@mlwwrites That's the way I read them. Makes sense

Q โๆ 0

CTV News

@CTVNews

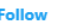

New Kickstarter rules offer would-be backers more protection ow.ly/BLXpg

7:34 am - 22 Sep 2014

3 Retweets 1 Like RE

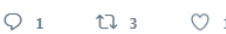

Omilesmaker 1

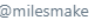

Follow

Kickstarter's New Rules:

You can't just take your $\$$ and run.

Complete projects, or fess up!

kickstarter.com/terms-of-use\#s...

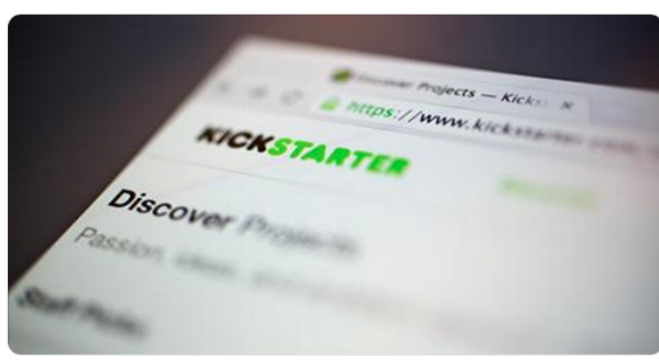

4:07 pm - 22 Sep 2014

13 Retweets 2 Likes 900090

Q $\quad$ ใ $13 \quad 0$

This figure presents a collection of tweets discussing the change in Kickstarter's terms of use (Source: Twitter). 
Figure OA-7: Google Search Interest for Kickstarter Rules

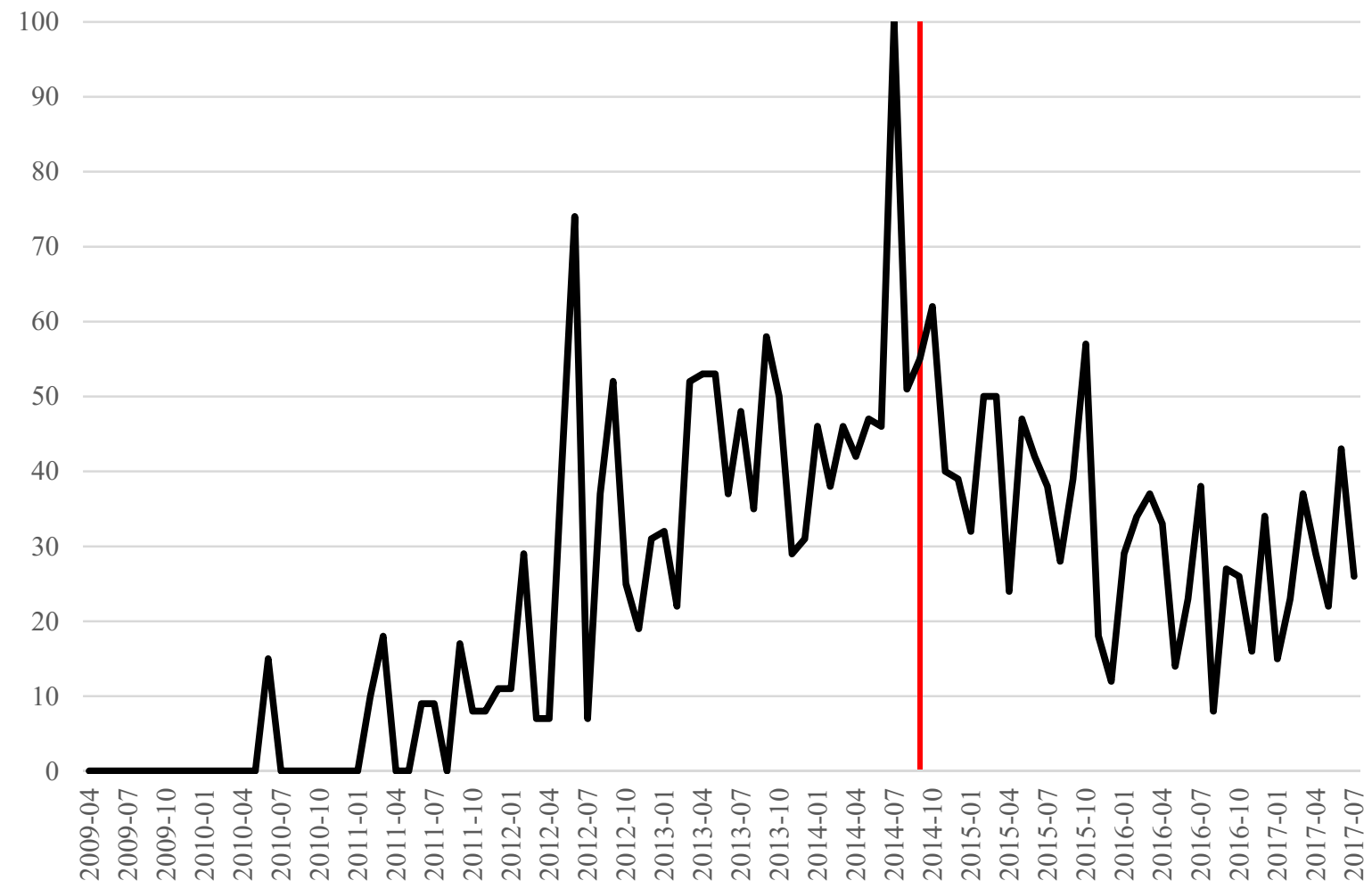

This figure depicts the Google search interest in the United States for Kickstarter rules relative to the highest point for the period (Source: Google Trends). The vertical line marks the date of the change in Kickstarter's terms of use. 
Figure OA-8: Kickstarter Web Traffic

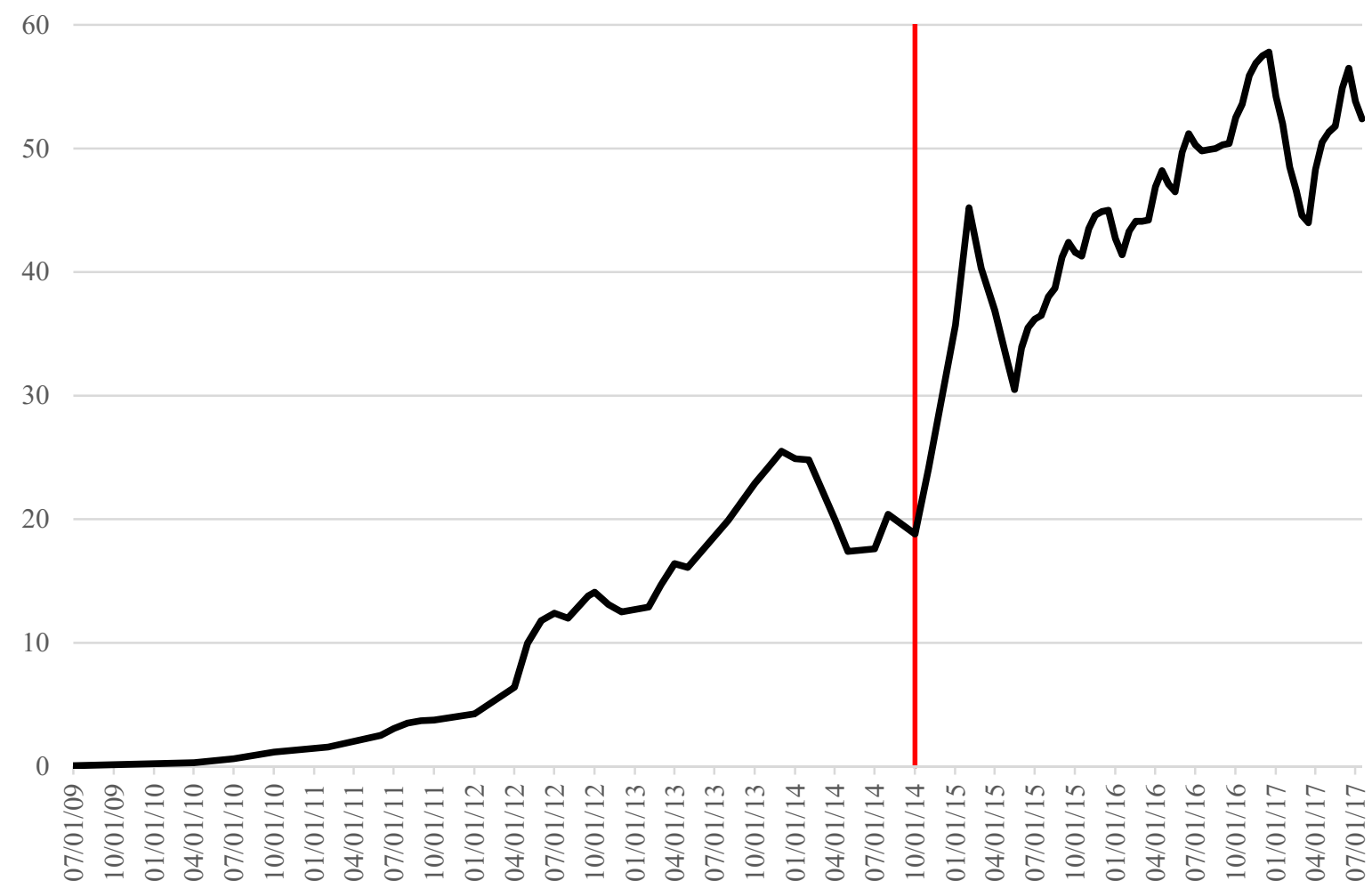

This figure shows the estimated number of desktop and mobile sessions on Kickstarter's website, in millions (Source: www.rank2traffic.com).The vertical line marks the date of the change in Kickstarter's terms of use. 
Figure OA-9: Aggregate Goal and Amount Pledged

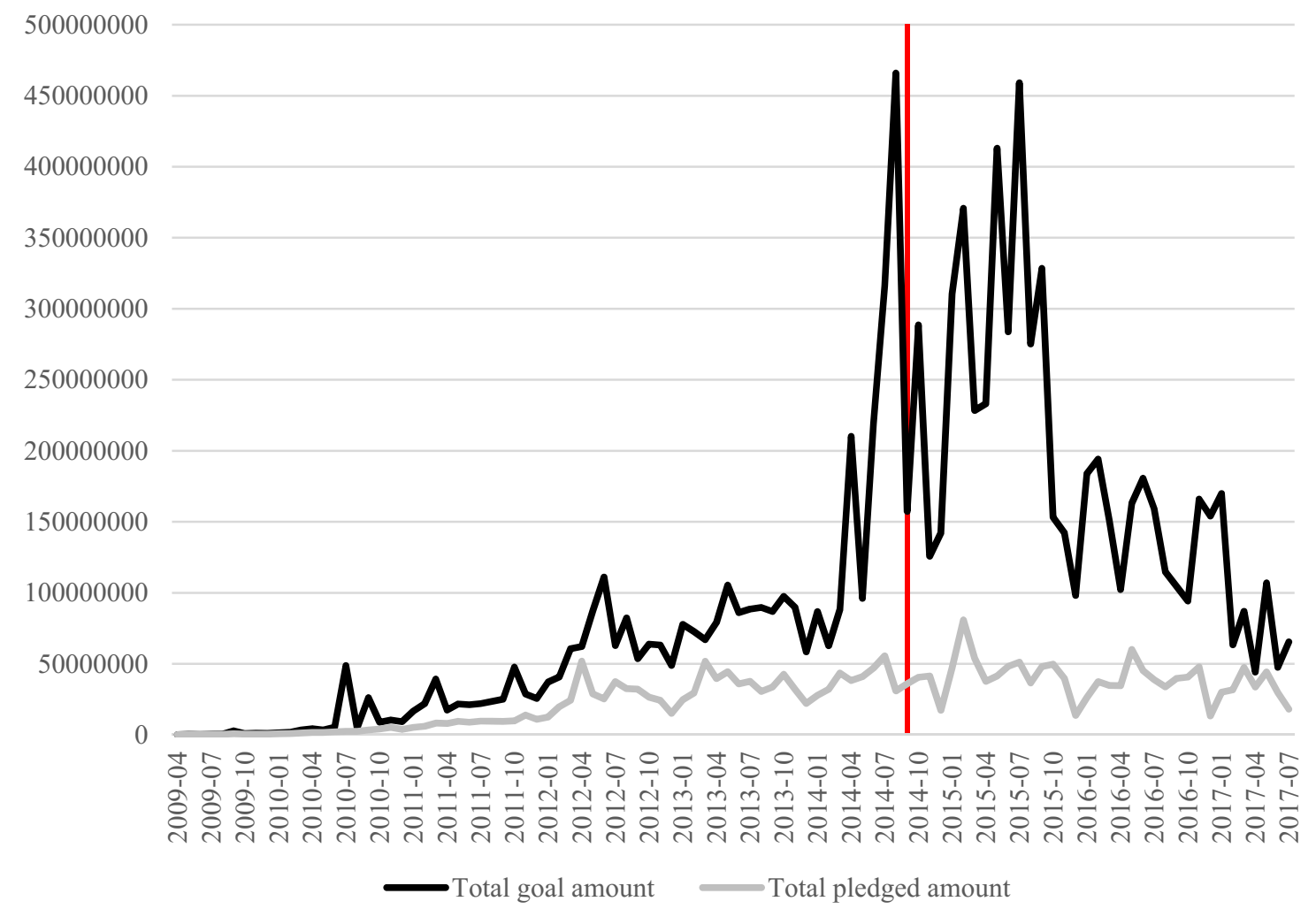

This figure shows the total goal amount and total amount pledged for our sample projects, in U.S. dollars (Source: Kickstarter). The vertical line marks the date of the change in Kickstarter's terms of use. 
Figure OA-10: Keyness of Project Disclosures

Panel A: Campaign Pitch

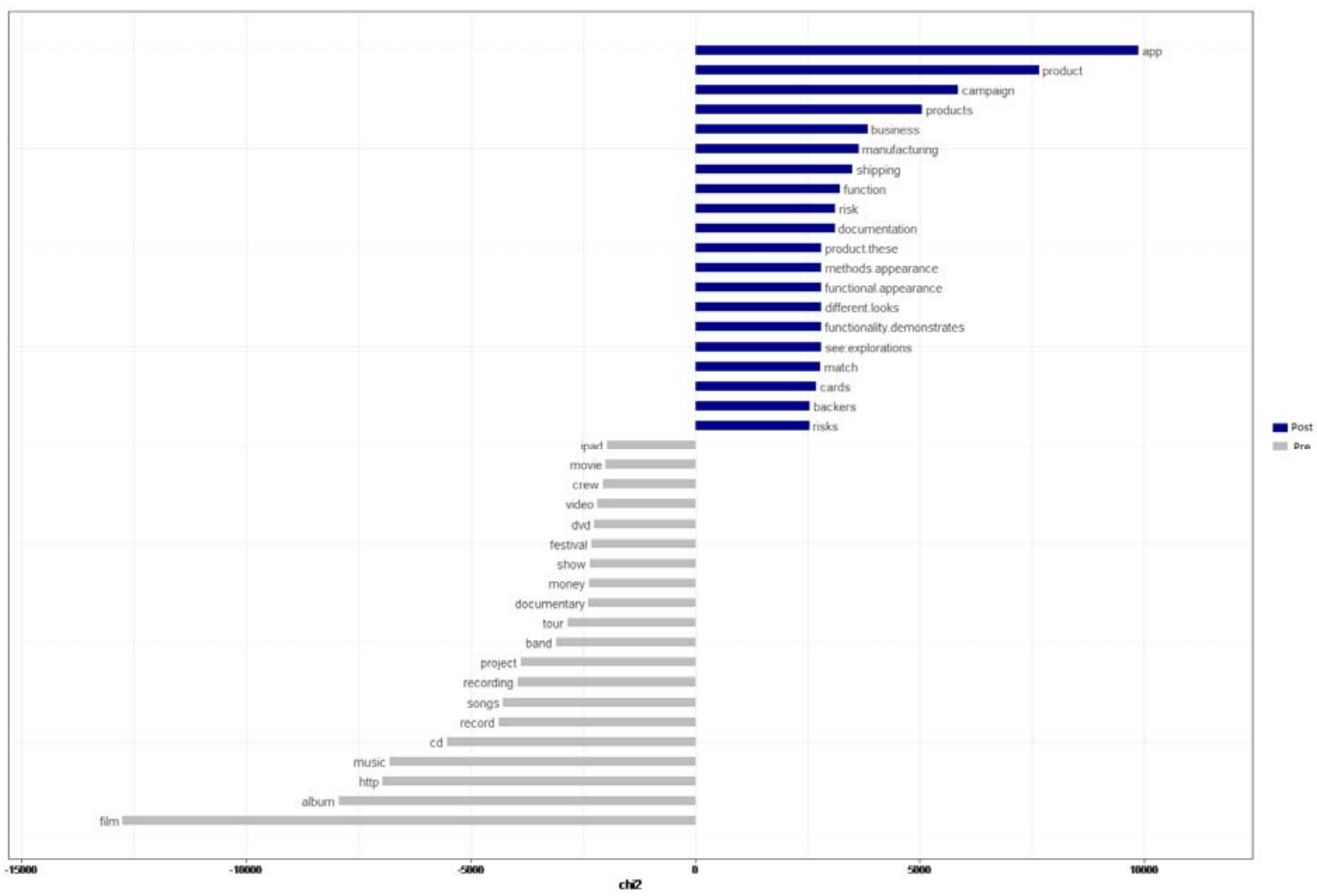


Figure OA-10 (continued)

Panel B: Risks and Challenges Section

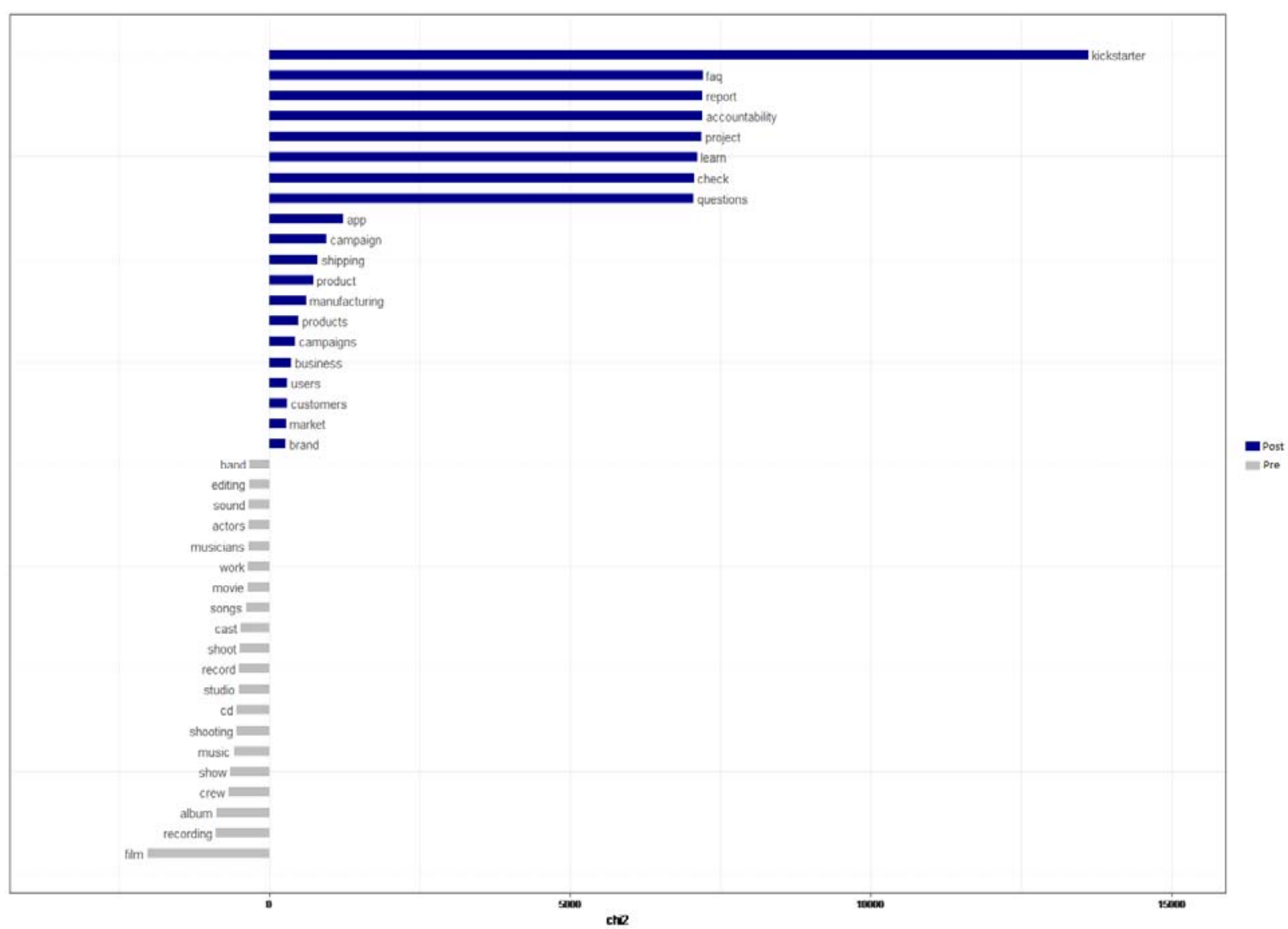

This figure compares the relative word frequencies in the campaign pitch (Panel A) and in the risks and challenges section (Panel B) before ('Pre') and after ('Post') the change in Kickstarter's terms of use. 
Table OA-1: Excerpts from Articles Covering the Change in Kickstarter's Terms of Use

\begin{tabular}{|c|c|c|c|}
\hline Date & Title & Link & Excerpt \\
\hline $09 / 19 / 2014$ & $\begin{array}{l}\text { Kickstarter } \\
\text { updates } \\
\text { terms to } \\
\text { address } \\
\text { creators } \\
\text { who fail to } \\
\text { deliver on } \\
\text { their } \\
\text { projects }\end{array}$ & $\begin{array}{l}\underline{\text { https://www.p }} \\
\underline{\text { olygon.com/2 }} \\
\underline{014 / 9 / 19 / 6559} \\
\underline{893 / \text { kickstarte }} \\
\underline{\text { r-terms-of- }} \\
\underline{\text { use-update- }} \\
\underline{\text { creators- }} \\
\text { failed-projects }\end{array}$ & $\begin{array}{l}\text { "Kickstarter is revising its terms of use in an effort to clarify } \\
\text { the relationship between project creators and backers, and in } \\
\text { particular, to spell out the responsibilities that creators have } \\
\text { to their backers, the company announced today. } \\
\text { (...)Kickstarter considers the backing arrangement to be a } \\
\text { binding legal agreement between creators and backers, with } \\
\text { creators being legally obligated to fulfill the project and any } \\
\text { associated rewards.(..) the terms of use explicitly warn } \\
\text { creators that if they don't meet those standards, they open } \\
\text { themselves up to possible legal action from backers." }\end{array}$ \\
\hline $09 / 19 / 2014$ & $\begin{array}{l}\text { Kickstarter } \\
\text { changes } \\
\text { rules so } \\
\text { nobody runs } \\
\text { off with } \\
\text { your money }\end{array}$ & $\begin{array}{l}\frac{\text { https://www.sl }}{\text { ashgear.com/k }} \\
\text { ickstarter- } \\
\text { changes-rules- } \\
\text { so-nobody- } \\
\text { runs-off-with- } \\
\text { your-money- } \\
\text { 19347238/ }\end{array}$ & $\begin{array}{l}\text { "If you've ever back a crowd-funded campaign, you know that } \\
\text { feeling you get just after submitting your cash. It sometimes } \\
\text { comes back months later, when the project goes off the rails or } \\
\text { hits a snag. Will you ever see the thing you paid for? } \\
\text { Kickstarter is making sure you will, even threatening } \\
\text { litigation." }\end{array}$ \\
\hline $09 / 19 / 2014$ & $\begin{array}{l}\text { Kickstarter } \\
\text { updates } \\
\text { terms of use } \\
\text { section } \\
\text { related to } \\
\text { failed } \\
\text { projects }\end{array}$ & $\begin{array}{l}\frac{\text { https://techcru }}{\text { nch.com/2014/ }} \\
\frac{09 / 19 / \text { kickstar }}{\text { ter-updates- }} \\
\frac{\text { terms-of-use- }}{\text { section- }} \\
\text { related-to- } \\
\text { failed- } \\
\text { projects/ }\end{array}$ & $\begin{array}{l}\text { "In Section } 4 \text { of Kickstarter's revised Terms of Use, the } \\
\text { company now explains that when customers are backing a } \\
\text { project, they're creating a legal agreement between themselves } \\
\text { and the project creators, not with Kickstarter. (...) Kickstarter } \\
\text { also reminds creators that they need to be "honest" and not } \\
\text { make "material misrepresentations in their communication to } \\
\text { backers. (In other words, scammers beware.) Additionally, the } \\
\text { terms now state that creators who are unable to stand by the } \\
\text { promises they made in their project may be subject to legal } \\
\text { action by backers. (The possibility of legal action has always } \\
\text { existed, but that part was not spelled out clearly in the previous } \\
\text { terms.)" }\end{array}$ \\
\hline $09 / 19 / 2014$ & $\begin{array}{l}\text { Kickstarter } \\
\text { outlines } \\
\text { what project } \\
\text { creators } \\
\text { must do if } \\
\text { they don't } \\
\text { deliver on } \\
\text { promises }\end{array}$ & $\begin{array}{l}\frac{\text { https://venture }}{\text { beat.com/2014 }} \\
\text { /09/19/kicksta } \\
\text { rter-outlines- } \\
\text { what-project- } \\
\text { creators-must- } \\
\text { do-if-they- } \\
\text { dont-deliver- } \\
\text { on-promises/ }\end{array}$ & $\begin{array}{l}\text { "That's what Kickstarter describes in an update made to its } \\
\text { terms of service today. According to the changes, "Anyone } \\
\text { who backs a project is accepting the creator's offer, and } \\
\text { forming that contract. Kickstarter is not a part of this } \\
\text { contract," reads the new terms of service. (...) Kickstarter } \\
\text { cautions, however, that doing the above may, not } \\
\text { protect project creators from "legal action by backers."," }\end{array}$ \\
\hline $09 / 19 / 2014$ & $\begin{array}{l}\text { Kickstarter: } \\
\text { Project } \\
\text { Backers } \\
\text { Must Get } \\
\text { Rewards } \\
\text { (But Leave } \\
\text { Us Out Of } \\
\text { It) }\end{array}$ & $\begin{array}{l}\text { https://consum } \\
\text { erist.com/2014 } \\
\text { /09/19/kicksta } \\
\text { rter-project- } \\
\underline{\text { backers-must- }} \\
\text { get-rewards- } \\
\text { but-leave-us- } \\
\text { out-of-it/ }\end{array}$ & $\begin{array}{l}\text { "Today, Kickstarter announced that it has revised its Terms to } \\
\text { make them more readable and to include an entire section that } \\
\text { spells out creators' obligations to their backers. The section, } \\
\text { entitled "How Projects Work," puts this duty in language that } \\
\text { leaves less room for interpretation. "When a project is } \\
\text { successfully funded, the creator must complete the project and } \\
\text { fulfill each reward," reads the updated Terms (bolding in } \\
\text { original text). "Once a creator has done so, they've satisfied } \\
\text { their obligation to their backers." }\end{array}$ \\
\hline
\end{tabular}


Table OA-1 (continued)

\begin{tabular}{|c|c|c|c|}
\hline Date & Title & Link & Excerpt \\
\hline $09 / 20 / 2014$ & $\begin{array}{l}\text { Kickstarter } \\
\text { changes } \\
\text { terms of } \\
\text { service, } \\
\text { wants } \\
\text { projects } \\
\text { finished }\end{array}$ & $\begin{array}{l}\underline{\text { https://betane }} \\
\underline{\text { ws.com/2014/ }} \\
\underline{09 / 20 / \text { kickstar }} \\
\underline{\text { ter-changes- }} \\
\text { terms-of- } \\
\text { service-wants- } \\
\text { projects- } \\
\text { finished/ }\end{array}$ & $\begin{array}{l}\text { "Now the service is trying to clean things up with a new terms } \\
\text { of service agreement that it hopes will lend more confidence to } \\
\text { potential backers. That should be a good thing for customers, } \\
\text { and Kickstarter spells things out pretty clearly. "For the } \\
\text { overwhelming majority of projects, it's pretty simple: creators } \\
\text { finish the work they planned, backers are happy, and nobody } \\
\text { sweats the details. But there are exceptions. Sometimes } \\
\text { problems come up, projects don't go according to plan, and } \\
\text { people wind up in the dark about what's supposed to happen } \\
\text { next. So we're spelling it out-- what's expected from backers, } \\
\text { what's expected from creators, and what needs to happen if a } \\
\text { project runs into trouble", says Yancey Strickler." }\end{array}$ \\
\hline $09 / 21 / 2014$ & $\begin{array}{l}\text { Kickstarter } \\
\text { clarifies } \\
\text { creator } \\
\text { accountabili } \\
\text { ty. A hefty } \\
\text { overhaul of } \\
\text { Kickstarter' } \\
\text { s terms of } \\
\text { use clarifies } \\
\text { creator } \\
\text { obligations } \\
\text { and } \\
\text { potential } \\
\text { consequenc } \\
\text { es of not } \\
\text { fulfilling } \\
\text { their end of } \\
\text { the deal }\end{array}$ & $\begin{array}{l}\text { https://www.c } \\
\text { net.com/news/ } \\
\text { kickstarter- } \\
\text { updates-terms- } \\
\text { of-use-to- } \\
\text { clarify- } \\
\text { creator- } \\
\text { accountability/ }\end{array}$ & $\begin{array}{l}\text { "The crowdfunding website has recently updated its terms of } \\
\text { use to clarify creator obligations -- including the obligation to } \\
\text { issue a refund if the creator cannot deliver on promised } \\
\text { rewards and the possibility of legal action from backers. } \\
\text { Previously, the old terms of use buried this information in a } \\
\text { wall of text. "Project Creators agree to make a good faith } \\
\text { attempt to fulfill each reward by its Estimated Delivery Date," } \\
\text { it stated in one point; and, in another, "Kickstarter does not } \\
\text { offer refunds. A Project Creator is not required to grant a } \\
\text { Backer's request for a refund unless the Project Creator is } \\
\text { unable or unwilling to fulfill the reward. Project Creators are } \\
\text { required to fulfill all rewards of their successful fundraising } \\
\text { campaigns or refund any Backer whose reward they do not or } \\
\text { cannot fulfill." The updated terms of use, which have also been } \\
\text { edited with clearer language and page layout, expand on this } \\
\text { obligation in no uncertain terms." }\end{array}$ \\
\hline $09 / 22$ & $\begin{array}{l}\text { Kickstarter' } \\
\text { s New } \\
\text { Rules: } \\
\text { Creators } \\
\text { Must } \\
\text { Complete } \\
\text { Projects, or } \\
\text { Fess Up }\end{array}$ & $\begin{array}{l}\underline{\text { https:/www.n }} \\
\underline{\text { bcnews.com/te }} \\
\text { ch/innovation/ } \\
\text { kickstarters- } \\
\text { new-rules- } \\
\text { creators-must- } \\
\text { complete- } \\
\text { projects-or- } \\
\text { fess-n209011 }\end{array}$ & $\begin{array}{l}\text { "Crowdfunding campaigns can help turn creators' dreams } \\
\text { into reality -- unless backers hand over the money, just to } \\
\text { watch everything fall apart. Now Kickstarter is trying to codify } \\
\text { the current swampy situation around projects canceled after } \\
\text { creators have the cash in hand. Kickstarter's new policies } \\
\text { mandate that creators complete their projects, or at least make } \\
\text { their best effort to bring the project to the "best possible } \\
\text { conclusion for backers." If creators don't make good on the } \\
\text { promises made in their campaigns, they must explain what } \\
\text { happened, return any unused funds, and could face potential } \\
\text { legal action from backers."," }\end{array}$ \\
\hline $09 / 22 / 2014$ & $\begin{array}{l}\text { Kickstarter } \\
\text { lays down } \\
\text { new rules } \\
\text { for when a } \\
\text { project fails }\end{array}$ & $\begin{array}{l}\underline{\text { https://arstech }} \\
\text { nica.com/infor } \\
\underline{\text { mation- }} \\
\text { technology/20 } \\
\underline{14 / 09 / \text { kickstar }} \\
\text { ter-tries-to- } \\
\text { help-creators- } \\
\text { who-dont- } \\
\text { deliver-with- } \\
\text { new-terms/ }\end{array}$ & $\begin{array}{l}\text { "Section } 4 \text { of the new terms of service goes to lengths to help } \\
\text { project creators set themselves up for success and/or not } \\
\text { frustrate their backers. If the creators can't deliver, Kickstarter } \\
\text { explains how to try and make good when the creators do not } \\
\text { fulfill their goals or backer rewards." }\end{array}$ \\
\hline
\end{tabular}

(continued) 
Table OA-1 (continued)

\begin{tabular}{|c|c|c|c|}
\hline Date & Title & Link & Excerpt \\
\hline $09 / 22 / 2014$ & $\begin{array}{l}\text { Kickstarter } \\
\text { changes } \\
\text { terms } \\
\text { regarding } \\
\text { unfinished } \\
\text { projects }\end{array}$ & $\begin{array}{l}\frac{\text { https://www.e }}{\text { ngadget.com/2 }} \\
\underline{014 / 09 / 22 / \text { kic }} \\
\text { kstarter- } \\
\text { changes- } \\
\text { terms-to- } \\
\text { resolve-failed- } \\
\text { projects/ }\end{array}$ & $\begin{array}{l}\text { "Kickstarter updated its terms of use late last week, mostly } \\
\text { cleaning up the site's fine-print language to better spell out the } \\
\text { relationship between project creators and backers (...) The } \\
\text { boldest inclusion stressed that creators who are unable to } \\
\text { satisfy the terms "may be subject to legal action by backers." } \\
\text { While Kickstarter still won't involve itself in the proceedings, } \\
\text { this opens a clearer lane for possible lawsuits from project } \\
\text { backers should creators fail to live up to their agreement or } \\
\text { offer alternative solutions." }\end{array}$ \\
\hline $09 / 22 / 2014$ & $\begin{array}{l}\text { The } \\
\text { Switchboar } \\
\text { d: Google } \\
\text { and Others } \\
\text { Feel Crush } \\
\text { of Chinese } \\
\text { Internet } \\
\text { Clamp } \\
\text { Down }\end{array}$ & $\begin{array}{l}\frac{\text { https://www.w }}{\text { ashingtonpost. }} \\
\text { com/news/the- } \\
\text { switch/wp/201 } \\
\text { 4/09/22/the- } \\
\text { switchboard- } \\
\text { google-and- } \\
\text { others-feel- } \\
\text { crush-of- } \\
\text { chinese- } \\
\text { internet- } \\
\text { clamp-down/ }\end{array}$ & $\begin{array}{l}\text { "Kickstarter lays down new rules for when a project fails. Just } \\
\text { because a Kickstarter raises funds, that doesn't mean it will } \\
\text { ultimately succeed. And now, Casey Johnston and Ars } \\
\text { Technica reports, the crowdfunding platform has updated its } \\
\text { terms of use with guidance for what to do when a project fails. } \\
\text { "In that event, creators are expected to explain what is } \\
\text { happening and how the money was used, giving refunds to any } \\
\text { backers who request them. Kickstarter also writes that, in lieu } \\
\text { of giving refunds, backers can "explain how those funds will } \\
\text { be used to complete the project in some alternate form." which } \\
\text { provides a loophole for a creator to keep a project in eternal } \\
\text { development hell." }\end{array}$ \\
\hline $09 / 22 / 2014$ & $\begin{array}{l}\text { Kickstarter } \\
\text { outline } \\
\text { contract } \\
\text { between } \\
\text { creator \& } \\
\text { backer }\end{array}$ & $\begin{array}{l}\underline{\text { https://www.r }} \\
\text { ockpapershotg } \\
\underline{\text { un.com/2014/ }} \\
\underline{\text { 09/22/kickstar }} \\
\text { ter-creator- } \\
\underline{\text { back-contract- }} \\
\underline{\text { terms-update/ }}\end{array}$ & $\begin{array}{l}\text { "The section ends with the most important part: "If [the } \\
\text { creator is] unable to satisfy the terms of this agreement, they } \\
\text { may be subject to legal action by backers." I'm not aware of } \\
\text { any videogame backers currently pursuing legal action } \\
\text { against a failed project, but this might give people a stronger } \\
\text { leg to stand upon should they choose to. Kickstarter is great, } \\
\text { but as John pointed out, backing a project is not the same thing } \\
\text { as buying a game. It's a risky investment, and while individual } \\
\text { pledges tend to be in low enough amounts that no single person } \\
\text { is accepting much risk, failures are inevitable. I'm glad } \\
\text { therefore that Kickstarter have written something that backers } \\
\text { can point to when developers occasionally fail to deliver or fall } \\
\text { silent for protracted periods of time." }\end{array}$ \\
\hline $09 / 22 / 2014$ & $\begin{array}{l}\text { It just got } \\
\text { easier to sue } \\
\text { failed } \\
\text { Kickstarter } \\
\text { campaigns } \\
\text { for a refund }\end{array}$ & $\begin{array}{l}\text { http://valleyw } \\
\text { ag.gawker.co } \\
\text { m/it-just-got- } \\
\text { easier-to-sue- } \\
\text { failed- } \\
\text { kickstarter- } \\
\underline{\text { campaigns- }} \\
\underline{1637720027}\end{array}$ & $\begin{array}{l}\text { "Kickstarter has decided to update its famously laissez-faire } \\
\text { attitude when it comes to protecting donors who have pledged } \\
\text { more than \$1 billion through the company over the years. The } \\
\text { new terms state that a successfully funded campaign that fails } \\
\text { to produce "rewards," i.e. the product, may have to "return } \\
\text { remaining funds." If not, they could be "subject to legal action } \\
\text { by backers." Backers could previously sue campaign creators, } \\
\text { but rarely did so. The new rules, which go into effect on } \\
\text { October } 19 \text { th, make the potential for a lawsuit more explicit } \\
\text { (check out the differences here). The amended TOS says that } \\
\text { by backing a project, donors are entering into a "contract" } \\
\text { with creators. Kickstarter then lists all the things a creator has } \\
\text { to do if a product does not materialize, including "offer to } \\
\text { return any remaining funds." If creators fails to bring the } \\
\text { contract to the "best possible conclusion," the "legal action" } \\
\text { part kicks in." }\end{array}$ \\
\hline
\end{tabular}

(continued) 
Table OA-1 (continued)

\begin{tabular}{|c|c|c|c|}
\hline Date & Title & Link & Excerpt \\
\hline $09 / 22 / 2014$ & $\begin{array}{l}\text { Flaky } \\
\text { Entrepreneu } \\
\text { rs Slapped } \\
\text { with } 5 \text { New } \\
\text { Kickstarter } \\
\text { Standards }\end{array}$ & $\begin{array}{l}\frac{\text { Upstart }}{\text { Business }} \\
\frac{\text { Journal Online }}{\text { (available on }} \\
\text { Factiva) }\end{array}$ & $\begin{array}{l}\text { "Kickstarter is no longer the risk-free testing ground many an } \\
\text { inexperienced entrepreneur once thought it was. Thanks to } \\
\text { changes to the Brooklyn, New York-based crowdfunding site's } \\
\text { Terms of Use, the possible repercussions to irresponsible } \\
\text { business managers are now quite clear, as are the steps to } \\
\text { avoid getting caught on the wrong side of a swarm of angry } \\
\text { backers (...) In case there is any confusion about the future role } \\
\text { Kickstarter may or may not play (...) the new terms make it } \\
\text { clear that when a creator and a supporter enter into an } \\
\text { agreement through the exchange of funds the contract doesn't } \\
\text { include Kickstarter. "If they're unable to satisfy the terms of } \\
\text { this agreement, they may be subject to legal action by } \\
\text { backers."," }\end{array}$ \\
\hline $09 / 22 / 2014$ & $\begin{array}{l}\text { Kickstarter } \\
\text { updates } \\
\text { terms for } \\
\text { successful- } \\
\text { then- } \\
\text { cancelled } \\
\text { projects }\end{array}$ & $\begin{array}{l}\text { https://www.e } \\
\text { urogamer.net/ } \\
\text { articles/2014- } \\
\text { 09-22- } \\
\text { kickstarter- } \\
\text { updates-terms- } \\
\text { for-successful- } \\
\text { then- } \\
\text { pancelled- } \\
\text { projects }\end{array}$ & $\begin{array}{l}\text { "These new terms echo those which were in place, but are } \\
\text { more strongly worded. That final term is key: "The creator is } \\
\text { solely responsible for fulfilling the promises made in their } \\
\text { project. If they're unable to satisfy the terms of this agreement, } \\
\text { they may be subject to legal action by backers."," }\end{array}$ \\
\hline $09 / 24 / 2014$ & $\begin{array}{l}\text { Kickstarter } \\
\text { is backing } \\
\text { the backers, } \\
\text { changes } \\
\text { terms of use }\end{array}$ & $\begin{array}{l}\text { https://vulcanp } \\
\text { ost.com/18388 } \\
\text { 1/kickstarter- } \\
\text { is-backing- } \\
\text { the-backers- } \\
\text { changes- } \\
\text { terms-of-use/ }\end{array}$ & $\begin{array}{l}\text { "These rules are intended to clarify a creator's accountability } \\
\text { and what they should do to avoid getting sued, when/if their } \\
\text { projects fail. This change will let the backer understand why a } \\
\text { certain project failed and they will also be able to understand } \\
\text { every action that the creator took during the course of the } \\
\text { project (...) These changes will be in effect from the } 19^{\text {th }} \\
\text { October 2014, and these stipulations ensure that creators } \\
\text { avoid any legal action if they are unable to finish their project. } \\
\text { However, backers can still sue if they feel like it." }\end{array}$ \\
\hline $10 / 01 / 2014$ & $\begin{array}{l}\text { Kickstarter } \\
\text { Backers Are } \\
\text { Investors, } \\
\text { and It's } \\
\text { Time They } \\
\text { Got Used } \\
\text { To It }\end{array}$ & $\begin{array}{l}\underline{\text { http://time.co }} \\
\text { m/money/341 } \\
\text { 9108/kickstart } \\
\text { er-backers- } \\
\text { are-investors- } \\
\text { and-its-time- } \\
\underline{\text { they-got-used- }} \\
\underline{\text { to-it/ }}\end{array}$ & $\begin{array}{l}\text { "Recently, Kickstarter appeared to respond to the bad press } \\
\text { by revising its terms of service. The new document does a } \\
\text { better job of laying out the responsibilities creators have to } \\
\text { their backers. No scamming, do your best, try to make it up to } \\
\text { people if you fail, and so on. But that move likely won't fix the } \\
\text { deeper problem. That most of the site's users believe that their } \\
\text { donations entitle them to some kind of tangible reward, be it a } \\
\text { smart watch or a bamboo beer koozie. In reality, nothing of } \\
\text { the sort is guaranteed. That's because Kickstarter backers } \\
\text { aren't customers making a purchase. They're investors. And } \\
\text { like all investments, Kickstarter projects have a chance of } \\
\text { going bust. (...)Backers generally have limited information } \\
\text { about the people they are supporting. And once a project is } \\
\text { funded, they're on their own when it comes to enforcing } \\
\text { contracts with a creators - to the extent that such contracts } \\
\text { even exist. In the event that a scammer takes everyone's money } \\
\text { and runs, Kickstarter won't offer a refund or even chip in for } \\
\text { legal fees. But at least in those cases there's a clear basis for } \\
\text { taking legal action (fraud); when money is squandered in a } \\
\text { more conventional way - through bad business decisions - } \\
\text { funders have no recourse at all." }\end{array}$ \\
\hline
\end{tabular}

(continued) 
Table OA-1 (continued)

\begin{tabular}{|c|c|c|c|}
\hline Date & Title & Link & Excerpt \\
\hline $10 / 22 / 2014$ & $\begin{array}{l}\text { Kickstarter' } \\
\text { s New } \\
\text { Terms of } \\
\text { Service } \\
\text { Agreement: } \\
\text { Complete } \\
\text { Your } \\
\text { Projects }\end{array}$ & $\begin{array}{l}\frac{\text { https://revisio }}{\text { nlegal.com/cro }} \\
\text { wdfunding- } \\
\text { lawyer/kicksta } \\
\text { rters-new- } \\
\text { terms-service- } \\
\text { agreement- } \\
\text { complete- } \\
\text { projects/ }\end{array}$ & $\begin{array}{l}\text { "Kickstarter, the donation-based crowdfunding platform, } \\
\text { recently made an important change to its Terms of Service. } \\
\text { Specifically, Kickstarter attempted to address the problem of } \\
\text { project creators failing to follow through with the project that } \\
\text { backers supported. Kickstarter did not mince words in its new } \\
\text { Terms of Service, stating. The creator is solely responsible for } \\
\text { fulfilling the promises made in their project. If they're unable } \\
\text { to satisfy the terms of this agreement, they may be subject to } \\
\text { legal action by backers. (...)If you are creating a project, } \\
\text { however, this should be a clear message: do not make } \\
\text { promises you cannot keep. With Kickstarter's new Terms of } \\
\text { Service, starting a project and fraudulently accepting } \\
\text { donations may expose creators to real liability." }\end{array}$ \\
\hline
\end{tabular}

This table reports a collection of excerpts from online articles announcing and describing the change in Kickstarter's terms of use. These articles specifically clarify the extent of increased threat of litigation faced by project creators following the rule change. 
Table OA-2: Web Traffic of Publications Covering the Change in Kickstarter's Terms of Use

\begin{tabular}{|c|c|c|}
\hline Website & October 1, 2014 & February 1, 2019 \\
\hline www.polygon.com & 4,800 & 34,300 \\
\hline www.slashgear.com & n.a. & 2,670 \\
\hline www.techcrunch.com & 32,000 & 25,400 \\
\hline$\underline{\text { www.venturebeat.com }}$ & n.a. & 5,940 \\
\hline$\overline{\text { Www.consumerist.com }}$ & n.a. & 402 \\
\hline www.betanews.com & n.a. & 3,300 \\
\hline 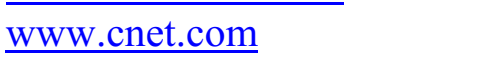 & 330,000 & 166,000 \\
\hline www.nbcnews.com & 80,000 & 80,500 \\
\hline Www.arstechnica.com & 17,000 & 30,000 \\
\hline www.engadget.com & 56,000 & 47,400 \\
\hline Www.washingtonpost.com & 97,000 & 181,000 \\
\hline www.rockpapershotgun.com & 3,820 & 14,200 \\
\hline www.valleywag.gawker.com & n.a. & n.a. \\
\hline www.bizjournals.com & 12,000 & 11,600 \\
\hline www.eurogamer.net & 6,710 & 32,900 \\
\hline$\overline{\text { Www.vulcanpost.com }}$ & n.a. & 485 \\
\hline www.time.com & 99,000 & 32,200 \\
\hline 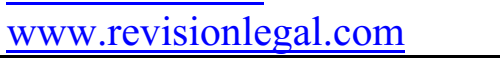 & n.a. & 18.1 \\
\hline
\end{tabular}


Table OA-3: FTC Consumer Complaints and Backer Comments

\begin{tabular}{|c|c|c|c|c|}
\hline & $\begin{array}{l}\text { Dependent variable: } \\
\text { Consumer Complaints }\end{array}$ & $\begin{array}{l}\text { Dependent variable: } \\
\text { Backer Sentiment }\end{array}$ & $\begin{array}{c}\text { Dependent variable: } \\
\text { Delay }\end{array}$ & $\begin{array}{c}\text { Dependent variable: } \\
\text { Fraud }\end{array}$ \\
\hline Independent variables: & $(1)$ & $(2)$ & $(3)$ & $(4)$ \\
\hline Post $\times$ Treated & $\begin{array}{l}0.003 * * \\
(2.52)\end{array}$ & $\begin{array}{l}0.002 * * \\
(2.37) \\
\end{array}$ & $\begin{array}{l}-0.001 * * \\
(-2.63)\end{array}$ & $\begin{array}{l}-0.002^{*} \\
(-1.99) \\
\end{array}$ \\
\hline State fixed effects & Yes & Yes & Yes & Yes \\
\hline Year-month fixed effects & Yes & Yes & Yes & Yes \\
\hline Obs. & 5,763 & 4,144 & 4,738 & 4,738 \\
\hline Adj. $\mathrm{R}^{2}$ & 0.152 & 0.047 & 0.177 & 0.124 \\
\hline
\end{tabular}

This table presents the results of the analysis that assesses the effects of the introduction of Kickstarter's new terms of use on the perception of creator legal liability and backer legal protection. Data are aggregated at the state and year level. The dependent variable is the number of consumer complaints in Column (1), the average sentiment of backer comments for successful (i.e., funded) projects in Column (2), the percentage of successful projects with backers discussing delays in Column (3), and the percentage of successful projects with fraud allegations by backers in Column (4). All model specifications are estimated using OLS and include state and year-month fixed effects. The table reports (in parentheses) $t$-statistics based on heteroscedasticity-robust standard errors clustered by state and year-month. $* * *, * *$, and $*$ denote statistical significance at the $1 \%$, $5 \%$, and $10 \%$ levels (two-tailed), respectively. 


\section{Table OA-4: Disclosure and Project Success by Size}

Dependent variable: Funded

\begin{tabular}{|c|c|c|c|c|c|c|c|c|}
\hline \multirow[b]{3}{*}{ Independent variables: } & \multicolumn{4}{|c|}{ Disclosure variable: Ln(Campaign Pitch) } & \multicolumn{4}{|c|}{ Disclosure variable: Ln(Risks and Challenges) } \\
\hline & Extra Small & Small & Medium & Large & Extra Small & Small & Medium & Large \\
\hline & $(1)$ & (2) & (3) & (4) & (5) & (6) & (7) & $(8)$ \\
\hline Disclosure & $0.020 * * *$ & $0.034 * * *$ & $0.036 * * *$ & $0.038 * * *$ & $0.043 * * *$ & $0.034 * * *$ & $0.033 * * *$ & $0.016^{* * *}$ \\
\hline & $(7.15)$ & $(11.17)$ & $(7.10)$ & $(7.27)$ & $(14.08)$ & $(9.23)$ & $(7.02)$ & $(4.21)$ \\
\hline Project controls & Yes & Yes & Yes & Yes & Yes & Yes & Yes & Yes \\
\hline Creator Controls & Yes & Yes & Yes & Yes & Yes & Yes & Yes & Yes \\
\hline Macro controls & Yes & Yes & Yes & Yes & Yes & Yes & Yes & Yes \\
\hline State fixed effects & Yes & Yes & Yes & Yes & Yes & Yes & Yes & Yes \\
\hline Subcategory $\times$ Year-month fixed effects & Yes & Yes & Yes & Yes & Yes & Yes & Yes & Yes \\
\hline Obs. & 108,724 & 50,823 & 26,528 & 68,942 & 75,526 & 36,412 & 20,131 & 56,846 \\
\hline Adj. $\mathrm{R}^{2}$ & 0.330 & 0.424 & 0.481 & 0.404 & 0.360 & 0.448 & 0.495 & 0.406 \\
\hline
\end{tabular}

Panel B: Amount Pledged

\begin{tabular}{|c|c|c|c|c|c|c|c|c|}
\hline \multirow[b]{4}{*}{ Independent variables: } & \multicolumn{8}{|c|}{ Dependent variable: Ln(Pledged) } \\
\hline & \multicolumn{4}{|c|}{ Disclosure variable: Ln(Campaign Pitch) } & \multicolumn{4}{|c|}{ Disclosure variable: Ln(Risks and Challenges) } \\
\hline & Extra Small & Small & Medium & Large & Extra Small & Small & Medium & Large \\
\hline & $(1)$ & $(2)$ & $(3)$ & $(4)$ & $(5)$ & $(6)$ & $(7)$ & $(8)$ \\
\hline Disclosure & $\begin{array}{l}0.252 * * * \\
(13.02)\end{array}$ & $\begin{array}{l}0.396^{* * *} \\
(12.08)\end{array}$ & $\begin{array}{l}0.442 * * * \\
(15.22)\end{array}$ & $\begin{array}{l}0.575 * * * \\
(22.79)\end{array}$ & $\begin{array}{l}0.219 * * * \\
(9.03)\end{array}$ & $\begin{array}{l}0.302 * * * \\
(14.65)\end{array}$ & $\begin{array}{l}0.313 * * * \\
(6.50)\end{array}$ & $\begin{array}{l}0.322 * * * \\
(8.73)\end{array}$ \\
\hline Project controls & Yes & Yes & Yes & Yes & Yes & Yes & Yes & Yes \\
\hline Creator controls & Yes & Yes & Yes & Yes & Yes & Yes & Yes & Yes \\
\hline Macro controls & Yes & Yes & Yes & Yes & Yes & Yes & Yes & Yes \\
\hline State fixed effects & Yes & Yes & Yes & Yes & Yes & Yes & Yes & Yes \\
\hline Subcategory $\times$ Year-month fixed effects & Yes & Yes & Yes & Yes & Yes & Yes & Yes & Yes \\
\hline Obs. & 108,724 & 50,823 & 26,528 & 68,942 & 75,526 & 36,412 & 20,131 & 56,846 \\
\hline Adj. $R^{2}$ & 0.267 & 0.410 & 0.512 & 0.479 & 0.289 & 0.438 & 0.534 & 0.483 \\
\hline
\end{tabular}

This table presents the results of the analysis that examines how the association between disclosure and project success varies according to project size. Extra small projects have a funding goal below U.S. $\$ 5,000$, Small projects have a funding goal that ranges between U.S. $\$ 5,000$ and U.S. $\$ 10,000$, Medium projects have a funding goal that ranges between U.S. \$10,000 and U.S. \$15,000, and Large projects have a funding goal above U.S. \$15,000. In Panel A (Panel B) the dependent variable is Funded (Ln(Pledged)). In both panels, Disclosure is measured as Ln(Campaign Pitch) and Ln(Risks and Challenges) in Columns (1) to (4) and (5) to (8), respectively. All model specifications are estimated using OLS and include project, creator, and macro-level control variables, as well as state and subcategory $\times$ year-month fixed effects. The table reports (in parentheses) $t$-statistics based on heteroscedasticity-robust standard errors clustered by state and year-month. ${ }^{* * *}, * *$, and $*$ denote statistical significance at the $1 \%, 5 \%$, and $10 \%$ levels (two-tailed), respectively. All variables are defined in Appendix B of the paper. 
Table OA-5: Additional Robustness Tests

Panel A: Intrastate Backers

\begin{tabular}{|c|c|c|c|c|}
\hline \multirow[b]{3}{*}{ Independent variables: } & \multicolumn{2}{|c|}{ Dependent variable: Funded } & \multicolumn{2}{|c|}{ "Dependent variable: Ln(Pledged) } \\
\hline & $\begin{array}{l}\text { Disclosure variable: } \\
\text { Ln(Campaign Pitch) }\end{array}$ & $\begin{array}{c}\text { Disclosure variable: } \\
\text { Ln(Risks and Challenges) }\end{array}$ & $\begin{array}{l}\text { Disclosure variable: } \\
\text { Ln(Campaign Pitch) }\end{array}$ & $\begin{array}{c}\text { Disclosure variable: } \\
\text { Ln(Risks and Challenges) }\end{array}$ \\
\hline & $(1)$ & $(2)$ & $(3)$ & $(4)$ \\
\hline \multirow[t]{2}{*}{ Disclosure } & -0.026 & 0.003 & 0.009 & 0.010 \\
\hline & $(-1.64)$ & $(0.18)$ & $(0.24)$ & $(0.29)$ \\
\hline \multirow[t]{2}{*}{ Post $\times$ Treated } & $-0.020 * * *$ & $-0.012 * * *$ & $-0.081 * * *$ & $-0.056 * * *$ \\
\hline & $(-4.38)$ & $(-2.78)$ & $(-5.75)$ & $(-5.06)$ \\
\hline \multirow[t]{2}{*}{ Disclosure $\times$ Post } & -0.004 & -0.008 & $-0.040 * * *$ & $-0.054 * * *$ \\
\hline & $(-0.76)$ & $(-1.26)$ & $(-3.57)$ & $(-3.58)$ \\
\hline \multirow[t]{2}{*}{ Disclosure $\times$ Treated } & -0.001 & -0.002 & -0.004 & -0.005 \\
\hline & $(-0.61)$ & $(-0.96)$ & $(-1.03)$ & $(-1.18)$ \\
\hline \multirow[t]{2}{*}{ Disclosure $\times$ Post $\times$ Treated } & $0.003 * * *$ & $0.003 * * *$ & $0.013 * * *$ & $0.012 * * *$ \\
\hline & $(4.33)$ & $(3.44)$ & $(5.80)$ & $(4.54)$ \\
\hline Project controls & Yes & Yes & Yes & Yes \\
\hline Creator controls & Yes & Yes & Yes & Yes \\
\hline Macro controls & Yes & Yes & Yes & Yes \\
\hline State fixed effects & Yes & Yes & Yes & Yes \\
\hline Subcategory $\times$ Year-month fixed effects & Yes & Yes & Yes & Yes \\
\hline Obs. & 30,351 & 22,585 & 30,351 & 22,585 \\
\hline Adj. $R^{2}$ & 0.435 & 0.442 & 0.486 & 0.497 \\
\hline
\end{tabular}


Table OA-5 (continued)

Panel B: Excluding Cancelled and Suspended Projects

\begin{tabular}{|c|c|c|c|c|}
\hline \multirow[b]{3}{*}{ Independent variables: } & \multicolumn{2}{|c|}{ Dependent variable: Funded } & \multicolumn{2}{|c|}{ "Dependent variable: Ln(Pledged) } \\
\hline & $\begin{array}{l}\text { Disclosure variable: } \\
\text { Ln(Campaign Pitch) }\end{array}$ & $\begin{array}{c}\text { Disclosure variable: } \\
\text { Ln(Risks and Challenges) }\end{array}$ & $\begin{array}{l}\text { Disclosure variable: } \\
\text { Ln(Campaign Pitch) }\end{array}$ & $\begin{array}{c}\text { Disclosure variable: } \\
\text { Ln(Risks and Challenges) }\end{array}$ \\
\hline & $(1)$ & $(2)$ & $(3)$ & $(4)$ \\
\hline Disclosure & $\begin{array}{l}0.012^{* * *} \\
(2.89)\end{array}$ & $\begin{array}{l}0.020^{* * *} \\
(4.82)\end{array}$ & $\begin{array}{l}0.348^{* * * *} \\
(8.59)\end{array}$ & $\begin{array}{l}0.220^{* * *} \\
(4.60)\end{array}$ \\
\hline Post $\times$ Treated & $\begin{array}{l}-0.025 * * * \\
(-7.45)\end{array}$ & $\begin{array}{l}-0.011 * * * \\
(-3.76)\end{array}$ & $\begin{array}{l}-0.142 * * * \\
(-6.41)\end{array}$ & $\begin{array}{l}-0.096^{* * *} \\
(-4.61)\end{array}$ \\
\hline Disclosure $\times$ Post & $\begin{array}{r}0.002 \\
(0.59)\end{array}$ & $\begin{array}{l}-0.000 \\
(-0.10)\end{array}$ & $\begin{array}{r}0.027 \\
(0.82)\end{array}$ & $\begin{array}{c}0.024 \\
(0.62)\end{array}$ \\
\hline Disclosure $\times$ Treated & $\begin{array}{l}-0.000 \\
(-0.18)\end{array}$ & $\begin{array}{c}-0.000 \\
(-0.11)\end{array}$ & $\begin{array}{l}-0.004 \\
(-0.83)\end{array}$ & $\begin{array}{l}-0.005 \\
(-1.15)\end{array}$ \\
\hline Disclosure $\times$ Post $\times$ Treated & $\begin{array}{l}0.004 * * * \\
(7.35)\end{array}$ & $\begin{array}{l}0.002 * * * \\
(3.68)\end{array}$ & $\begin{array}{l}0.025^{* * * *} \\
(6.52)\end{array}$ & $\begin{array}{l}0.023 * * * \\
(5.05)\end{array}$ \\
\hline Project controls & Yes & Yes & Yes & Yes \\
\hline Creator controls & Yes & Yes & Yes & Yes \\
\hline Macro controls & Yes & Yes & Yes & Yes \\
\hline State fixed effects & Yes & Yes & Yes & Yes \\
\hline Subcategory $\times$ Year-month fixed effects & Yes & Yes & Yes & Yes \\
\hline Obs. & 235,474 & 173,832 & 235,474 & 173,832 \\
\hline Adj. $R^{2}$ & 0.365 & 0.379 & 0.340 & 0.361 \\
\hline
\end{tabular}




\section{Table OA-5 (continued)}

Panel C: Excluding Projects of Creators that Have Launched Other Projects in the Past

\begin{tabular}{|c|c|c|c|c|}
\hline \multirow[b]{3}{*}{ Independent variables: } & \multicolumn{2}{|c|}{ Dependent variable: Funded } & \multicolumn{2}{|c|}{ "Dependent variable: Ln(Pledged) } \\
\hline & $\begin{array}{l}\text { Disclosure variable: } \\
\text { Ln(Campaign Pitch) }\end{array}$ & $\begin{array}{c}\text { Disclosure variable: } \\
\text { Ln(Risks and Challenges })\end{array}$ & $\begin{array}{l}\text { Disclosure variable: } \\
\text { Ln(Campaign Pitch) }\end{array}$ & $\begin{array}{c}\text { Disclosure variable: } \\
\text { Ln(Risks and Challenges) }\end{array}$ \\
\hline & $(1)$ & $(2)$ & $(3)$ & $(4)$ \\
\hline \multirow{2}{*}{ Disclosure } & 0.005 & $0.013 * * *$ & $0.335^{* * *}$ & $0.189 * * *$ \\
\hline & $(1.24)$ & $(2.95)$ & $(8.54)$ & $(3.74)$ \\
\hline \multirow[t]{2}{*}{ Post $\times$ Treated } & $-0.024 * * *$ & $-0.009 * * *$ & $-0.158 * * *$ & $-0.090 * * *$ \\
\hline & $(-6.27)$ & $(-3.14)$ & $(-5.17)$ & $(-3.08)$ \\
\hline \multirow[t]{2}{*}{ Disclosure $\times$ Post } & -0.001 & -0.003 & 0.011 & 0.001 \\
\hline & $(-0.18)$ & $(-1.44)$ & $(0.28)$ & $(0.03)$ \\
\hline \multirow[t]{2}{*}{ Disclosure $\times$ Treated } & 0.000 & 0.000 & -0.003 & -0.003 \\
\hline & $(0.82)$ & $(0.57)$ & $(-0.70)$ & $(-0.52)$ \\
\hline \multirow[t]{2}{*}{ Disclosure $\times$ Post $\times$ Treated } & $0.004 * * *$ & $0.002 * * *$ & $0.027 * * *$ & $0.022 * * *$ \\
\hline & $(6.40)$ & $(3.39)$ & $(5.49)$ & $(3.66)$ \\
\hline Project controls & Yes & Yes & Yes & Yes \\
\hline Creator controls & Yes & Yes & Yes & Yes \\
\hline Macro Controls & Yes & Yes & Yes & Yes \\
\hline State fixed effects & Yes & Yes & Yes & Yes \\
\hline Subcategory $\times$ Year-month fixed effects & Yes & Yes & Yes & Yes \\
\hline Obs. & 196,277 & 141,154 & 196,277 & 141,154 \\
\hline Adj. $\mathrm{R}^{2}$ & 0.351 & 0.353 & 0.330 & 0.350 \\
\hline
\end{tabular}

This table presents the results of three robustness tests. In Panel A, we limit the sample to projects for which more than 50\% of the top 10 backers are from the respective project's state. In Panel B, we exclude from the sample those projects that have been cancelled or suspended. In Panel C, we exclude projects of creators that have previously launched other projects on Kickstarter. In all panels, the dependent variable is Funded in Columns (1) and (2) and Ln(Pledged) in Columns (3) and (4) and Disclosure is measured as Ln(Campaign Pitch) in odd-numbered columns and Ln(Risks and Challenges) in even-numbered columns. All model specifications are estimated using OLS and include project, creator, and macro-level control variables, as well as state and subcategory $\times$ year-month fixed effects. The table reports (in parentheses) $t$-statistics based on heteroscedasticity-robust standard errors clustered by state and year-month. $* * *, * *$, and $*$ denote statistical significance at the $1 \%$, $5 \%$, and $10 \%$ levels (two-tailed), respectively. All variables are defined in Appendix B of the paper. 
Table OA-6: Treatment Effect Stability

\begin{tabular}{|c|c|c|c|c|}
\hline \multirow[b]{3}{*}{ Independent variables: } & \multicolumn{2}{|c|}{ Dependent variable: Funded } & \multicolumn{2}{|c|}{ Dependent variable: Ln(Pledged) } \\
\hline & $\begin{array}{l}\text { Disclosure variable: } \\
\text { Ln(Campaign Pitch) }\end{array}$ & $\begin{array}{c}\text { Disclosure variable: } \\
\text { Ln(Risks and Challenges) }\end{array}$ & $\begin{array}{l}\text { Disclosure variable: } \\
\text { Ln(Campaign Pitch) }\end{array}$ & $\begin{array}{c}\text { Disclosure variable: } \\
\text { Ln(Risks and Challenges) }\end{array}$ \\
\hline & $(1)$ & $(2)$ & $(3)$ & $(4)$ \\
\hline$\beta_{\text {Uncontrolled }}$ & 0.0058 & 0.0039 & 0.0361 & 0.0374 \\
\hline$R_{\text {Uncontrolled }}^{2}$ & 0.1795 & 0.1838 & 0.2288 & 0.2129 \\
\hline$\beta_{\text {Controlled }}$ & 0.0036 & 0.0019 & 0.0246 & 0.0227 \\
\hline$R_{\text {Controlled }}^{2}$ & 0.3540 & 0.3658 & 0.3314 & 0.3522 \\
\hline$\Delta$ & 2.7266 & 1.6496 & 2.2108 & 2.0464 \\
\hline
\end{tabular}

This table presents an estimate of the value of Delta $(\Delta)$, the relative degree of selection on observed and unobserved control variables for which the treatment effect would be zero, following the methodology developed by Oster (2019). The table presents the coefficient on the interaction term Post $\times$ Treated $\times$ Disclosure and the $\mathrm{R}^{2}$ from the estimation of our main specification (Table 3, Panel A, Columns (2) and (4) and Table 3, Panel B, Columns (1) and (2)) of the paper with ( $\beta_{\text {Controlled }}, R_{\text {Controlled }}^{2}$ and without $\left(\beta_{\text {Uncontrolled }}, R_{\text {Uncontrolled }}^{2}\right)$ project, creator, and macro-level control variables. Following the methodology proposed by Oster $(2019)$ we set $\mathrm{R}^{\max }$ (the $\mathrm{R}^{2}$ from a hypothetical regression of the outcome on treatment and both observed and unobserved control variables) equal to 1.3 multiplied by the $\mathrm{R}^{2}$ of the regression that includes all control variables (i.e., the controlled regression). 